\title{
Ultrastructural Studies on
}

\section{Graptolites, 1: The Periderm and} Its Derivatives in the Dendroidea and in Mastigograptus

\author{
ADAM URBANEK \\ and \\ KENNETH M. TOWE
}




\title{
SERIAL PUBLICATIONS OF THE SMITHSONIAN INSTITUTION
}

The emphasis upon publications as a means of diffusing knowledge was expressed by the first Secretary of the Smithsonian Institution. In his formal plan for the Institution, Joseph Henry articulated a program that included the following statement: "It is proposed to publish a series of reports, giving an account of the new discoveries in science, and of the changes made from year to year in all branches of knowledge." This keynote of basic research has been adhered to over the years in the issuance of thousands of titles in serial publications under the Smithsonian imprint, commencing with Smithsonian Contributions to Knowledge in 1848 and continuing with the following active series:

\author{
Smithsonian Annals of Flight \\ Smithsonian Contributions to Anthropology \\ Smithsonian Contributions to Astrophysics \\ Smithsonian Contributions to Botany \\ Smithsonian Contributions to the Earth Sciences \\ Smithsonian Contributions to Paleobiology \\ Smithsonian Contributions to Zoology \\ Smithsonian Studies in History and Technology
}

In these series, the Institution publishes original articles and monographs dealing with the research and collections of its several museums and offices and of professional colleagues at other institutions of learning. These papers report newly acquired facts, synoptic interpretations of data, or original theory in specialized fields. These publications are distributed by mailing lists to libraries, laboratories, and other interested institutions and specialists throughout the world. Individual copies may be obtained from the Smithsonian Institution Press as long as stocks are available.

S. Dillon Ripley

Secretary

Smithsonian Institution 


\title{
Ultrastructural Studies on
}

\section{Graptolites, 1: The Periderm and \\ Its Derivatives in the Dendroidea \\ and in Mastigograptus}

\author{
Adam Urbanek \\ and Kenneth $M$. Towe
}

\section{ISSUED:}

Mar 151974

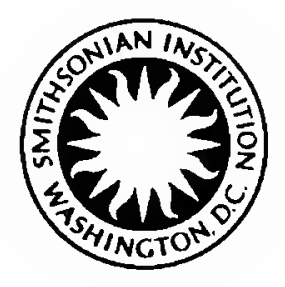

SMITHSONIAN INSTITUTION PRESS

City of Washington 


\begin{abstract}
A B S T R A C T
Urbanek, Adam, and Kenneth M. Towe. Ultrastructural Studies on Graptolites, 1: The Periderm and Its Derivatives in the Dendroidea and in Mastigograptus. Smithsonian Contributions to Paleobiology, number 20, 48 pages, 2 figures, 30 plates, 2 tables, 1974.-Organic skeletons of two dendroid graptolites and an aberrant sessile graptolite (Mastigograptus sp.), all Ordovician in age, were isolated chemically from the matrix and used subsequently for ultrastructural studies with the transmission electron microscope. Peridermal material of all forms investigated proved to be unusually well preserved as far as ultrastructural features are concerned, and it reveals a variety of fabrics and patterns classified into two structural categories: fabric and tissue. Following Kozlowski (1949) the term tissue is retained for larger structural components of the periderm, defined from a morphogenetic point of view. To distinguish the fusellar and cortical tissue, directly observed structures are classified as fabrics defined by the form of their unit elements and their spatial interrelations. Fusellar, cortical, sheet, and crassal fabrics were distinguished and characterized. Fusellar and cortical fabrics are both fibrillar but differ in fibril diameter. Fibrils are branched and wavy, or straight, producing a mesh, or showing a parallel arrangement and packed into layers. Sheet fabric is an electron dense, homogenous or densely reticulated material delimiting particular layers within the cortical tissue or producing an external pellicle on the fuselli. Crassal fabric is an electron dense and featureless material found in the sheath of stolons and as a secondary deposit inside the thecae in Mastigograptus sp. A given peridermal tissue is thus composed of more than one fabric, but with a predominance of either a fusellar or cortical one.

In addition to an earlier observation (Towe and Urbanek, 1972) that cortical fibrils are collagen-like, arguments are presented in favor of the opinion that fusellar fibrils may also represent the collagen group of fibrous proteins. Frequently observed passages of a single fusellar fibril within the body of a fusellus, into a fibril of an outer lamella of the same fusellus, showing a typically cortical arrangement of the fibrils, seems to indicate the same chemical nature of the fibrous components in both fabrics. Differences in their physical organization are here ascribed to the changes in the composition of the matrix.

The unexpected presence of a cortical coating on the inner thecal walls in Dictyonema sp. is explained through delayed growth of lateral thecae in the triad and very early deposition of cortical tissue over the outer surface of the young autotheca (autocortex). This wall is later overgrown by lateral thecae to become an inner thecal wall. A common cortical envelope secreted later over the outer surface of all thecae is called the rhabdocortex. The presence of a cortical component on the inner surface of the inner thecal walls in Acanthograptus sp. suggests, that at least in some dendroids also, the soft tissues inside the thecal cavity were capable of secretion of the cortical tissue. This changes the classical scheme of cortical tissue formation as proposed by Kozlowski (1949).

The fusellar tissue in Mastigograptus sp. reveals unusual, erratic distribution of fuselli, which are present only on certain places in the thecal wall. Over large areas these are substituted by a peculiar layer of electron dense, homogenous material termed here the crassal fabric. This is interpreted as a presumed secondary resorption and subsequent substitution of the fusellum by the crassal layer. The basal disc of Mastigograptus sp. is composed of a material resembling that in cortical fabric but with fewer fibrils embedded in abundant matrix. The lower layer of the basal disc is provided with numerous filaments made of delicate fibrils. The sclerotized sheaths of stolons recognized in Acanthograptus sp. are made mainly of the crassal fabric.
\end{abstract}

OfFicial publication date is handstamped in a limited number of initial copies and is recorded in the Institution's annual report, Smithsonian Year. SI Press NUMBer 5021. SERIES COVER DESIGN: The trilobite Phacops rana Green.

Library of Congress Cataloging in Publication Data

Urbanek, Adam

Ultrastructural studies on graptolites, 1: The Periderm and Its Derivatives in the Dendroidea and in Mastigograptus.

(Smithsonian contributions to paleobiology, no. 20)

1. Graptolites. 2. Paleontology-Ordovician. I. Towe, Kenneth M., joint author. II. Title.

III. Series: Smithsonian Institution. Smithsonian contributions to paleobiology, no. 20. QE701.S56 no. 20 [QE840.5] $560^{\prime} .8 \mathrm{~s} \quad\left[563^{\prime} .71\right] \quad 73-18097$

For sale by the Superintendent of Documents, U.S. Government Printing Office Washington, D.C. 20402 - Price $\$ 1.35$ 


\section{Contents}

Introduction

Acknowledgments $\ldots \ldots \ldots \ldots \ldots \ldots \ldots \ldots \ldots \ldots \ldots \ldots \ldots \ldots$

Origin and State of Preservation of Study Material .............. 1

Previous Studies on the Ultrastructure of Graptolite Periderm......... 2

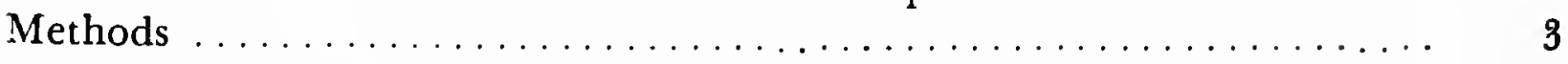

Microstructure of the Periderm in Dendroidea ............... 3

A Terminology for Ultrastructural Features in Dendroid Periderm..... 4

Major Structural Features of Graptolite Periderm ................. 4

The Fusellar Tissue ............................ 5

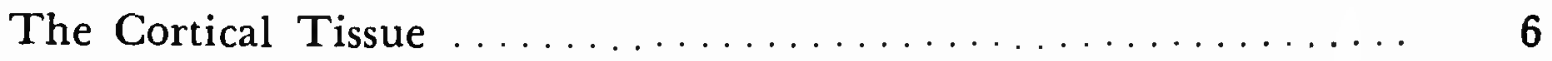

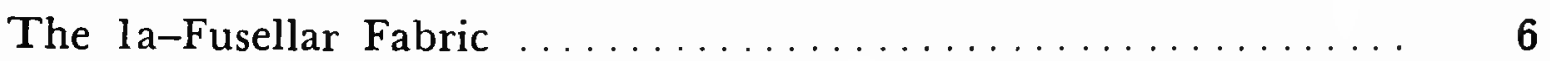

The 1 b-Cortical Fabric $\ldots \ldots \ldots \ldots \ldots \ldots \ldots \ldots \ldots \ldots \ldots \ldots \ldots$

The 1c-Sheet Fabrics .......................... 8

Composition of Cortical and Fusellar Fabrics ................ 9

Comparison with Previous Results ........................ 11

Ultrastructural Anatomy of the Thecal Walls ................ 11

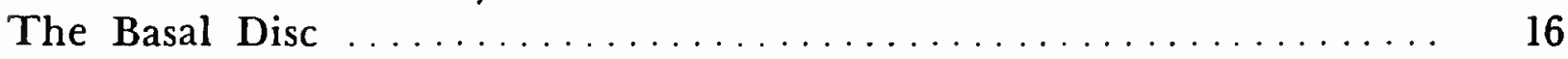

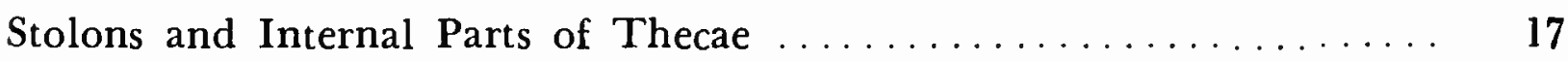

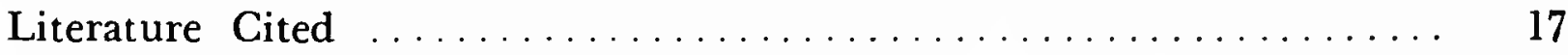





\title{
Ultrastructural Studies on Graptolites, 1: The Periderm and Its Derivatives in the Dendroidea and in Mastigograptus
}

\author{
Adam Urbanek \\ and Kenneth $M$. Towe
}

\section{Introduction}

The graptolites are an extinct group of marine, colonial organisms that achieved worldwide distribution during the Lower Paleozoic. Although the systematic position of this group of animals is not clearly established, they are generally placed among the Hemichordata, where their closest living relatives are presumed to be the Pterobranchs Rhabdopleura and Cephalodiscus. The skeletal periderm of the graptolites, like that of the Pterobranchs, is not mineralized and the fossil material is therefore normally preserved only as flattened, carbonized impressions on rock surfaces. However the existence of a wealth of unusually wellpreșerved, three-dimensional specimens from rocks in Poland provides ideal material to apply the ultramicrotome techniques of transmission electron microscopy to the study of graptolite microscopical and ultrastructural anatomy. The present paper is the first in a series of such studies. These are designed to cut across the broad range of graptolite taxa in order to provide a foundation and back-

Adam Urbanek, Faculty of Geology, University of Warsaw, 02-089 Warsaw, Poland. Kenneth M. Towe, Department of Paleobiology, National Museum of Natural History, Smithsontan Institution, Washington, D.C. 20560. ground for further ultrastructural studies of their internal anatomy.

AcKNowledgments. - This study was made possible through a visiting postdoctoral research award from the Office of Academic Studies of the Smithsonian Institution to Adam Urbanek. The Smithsonian Foreign Currency Program and the Zoological Committee of the Polish Academy of Sciences provided additional support to permit completion of the manuscript. We are grateful to Professor R. Kozlowski (Warsaw) for making portions of his collection available for study and to Drs. O. M. B. Bulman and R. B. Rickards (Cambridge) for discussion and comment on some portions of the work. Dr. Alwyn Williams (Belfast) and Dr. W. B. N. Berry (Berkeley) kindly reviewed a draft of the manuscript and provided us with helpful corrections and comments.

\section{Origin and State of Preservation of Study Material}

The material selected for the present study consists of fragments of skeletal rhabdosomes of two representative dendroid graptolites, Dictyonema sp. and Acanthograptus sp., as well as that of an aberrant, sessile graptolite, Mastigograptus sp. (incertae ordinis). All of the specimens have been etched 
with acetic acid from calcareous boulders of Baltic origin found in the Pleistocene glacial deposits of Poland.

The specimens of Dictyonema sp. were etched from an erratic boulder, less than $1 \mathrm{~kg}$ in weight, from Orlowo, near Gdynia (Eastern Pomerania, Baltic coast), at the foot of a high cliff consisting of moraine deposits. The boulder, numbered 0.62 in the collection of the Institute of Palaeontology in Warsaw, is an organogenic limestone and has furnished a rich assemblage of Dictyonema sp. accompanied by excellently preserved specimens of Discograptus schmidti Wiman. This latter graptolite is indicative of an Upper Ordovician age for the limestone from which the boulder was derived (Bulman and Rickards, 1966; Bulman, 1970). The specimens of Dictyonema sp. dissolved from the matrix consist of numerous branches with preserved dissepiments in places. Branches are partly deformed and the periderm is strongly "carbonized." Thecal cavities are frequently pyritized and the apertures of the autothecae filled by grains of quartz. In places the state of preservation of the material studied is mediocre as far as its microscopic features are concerned.

Specimens of Acanthograptus sp. were etched from an erratic boulder some $2.5 \mathrm{~kg}$ in weight, numbered 0.327, from Mochty, Valley of the Vistula River (60 km north of Warsaw, central Poland). The boulder is gray organogenic limestone (without glauconite), containing orthoconic nautiloids, rugose corals, rare scolecodonts, Dendrograptus sp. and the graptoloids Glyptograptus teretiusculus (Hisinger), Climacograptus distichus (Eichwald), and Pseudoclimacograptus angulatus cf. sebyensis Jaanusson. The graptoloid assemblage is indicative of a Middle Ordovician (Viruan) age and bears a particular resemblance to the fauna of the Schroeteri Limestone in Scania and the Seby Lime. stone of öland, both being the equivalent of older beds of the Lasnamägi Stage of Estonia (Jaanusson, 1960) and the Glossograptus hincksi Zone in the graptolite sequence.

The specimens of Mastigograptus sp. were also etched from an erratic boulder, $2 \mathrm{~kg}$ in weight, from Mochty, numbered 0.181 in the collection of the Institute of Palaeontology in Warsaw. The boulder is a light gray, organogenic and rather coarse-grained limestone. As well as containing very abundant and excellently preserved specimens of Mastigograptus sp., this boulder yielded Rhabdohydra tridens (Kozlowski, 1959), Clistrocystis graptolithophilius (Kozlowski, 1959, 1965), Gymnograptus sp. (Urbanek, 1959), and some crustoids (Kozlowski, 1962). None of these is indicative of the exact age of the limestone, although it is most probably Middle Ordovician (Viruan), Urbanek (1959:329).

\section{Previous Studies on the Ultrastructure of Graptolite Periderm}

In contrast to earlier microstructural studies on the periderm in the dendroids, investigations of ultrastructure among Graptolites have focused mainly on the Graptoloidea (Wetzel, 1958; Kraatz, 1964, 1968; Berry and Takagi, 1970, 1971; Rickards, Hyde, and Krinsley, 1971). In the dendroids Kraatz (1965) briefly described ultramicrotome cross sections through the thecal wall in Dictyonema rarum Wiman. The published figures are not micrographs and thus are strongly diagrammatical, and he distinguished two zones with differing structural patterns: (1) a wider zone made of numerous filament-like structures, placed partly parallel and partly oblique to the thecal wall, which he interpreted as a probable cortical tissue, and (2) a narrow zone formed by grain-like or spongy structures, and interpreted as a probable equivalent to the fusellar tissue. In a later paper (1968) and in an informal report to the Ludlow Research Group Bulletin (1968), Kraatz recognized within the thecal wall of Dictyonema (and in some graptoloids) different aggregates of particles and filaments, as unit elements of the ultrastructure.

Berry and Takagi (1970, 1971) described the periderm in diplograptids as consisting of a single layer of fusellar tissue, showing a meshwork structure, and of a multilayered cortical tissue built up of alternating layers of meshwork and fabric or fibrous structure. Berry and Takagi sectioned a few specimens with the ultramicrotome, but the bulk of their observations on the orientation of fibers in the fabric layer of the cortical tissue is based on unsectioned, small fragments of periderm placed directly on grids and examined with the transmission electron microscope. Although the observations of Berry and Takagi are based on graptoloid species, there are some important similarities 
to structures recognized in our Dictyonema sp., which are discussed at appropriate points below.

A study by Rickards, Hyde, and Krinsley (1971) was undertaken with the scanning electron microscope on a monograptid species. Although this paper contains interesting observations on surface structures of the periderm, it is difficult to correlate them with our observations on internal structures made with the transmission electron microscope. Some specific conclusions of Rickards et al. are discussed below.

\section{Methods}

Since the specimens, following their acetic acid isolation from the limestone, were stored in glycerine the procedure applied before embedding included washing in 70 percent ethanol, and subsequently in the standard graded alcohol series. The unbleached specimens were embedded in "Durcupan" ACM (Fluka). Subsequent operations followed the standard techniques as described in Pease (1964:82-190). Trimmed blocks were sectioned on a Porter-Blum MT-2 ultramicrotome provided with a DuPont diamond knife. Sections of an approximate thickness of $900 \AA$ proved suitable for the studies. They were placed on copper grids (100 mesh), which were coated with a film of "Parlodion" and carbon. No staining was used for subsequent examination with a Philips EM-200 transmission electron microscope, operated for optimum contrast at $40 \mathrm{kV}$ with a $25 \mu \mathrm{m}$ objective aperture. In a few cases higher voltages up to 100 $\mathrm{kV}$ were used to improve resolution on thicker sections.

\section{Microstructure of the Periderm in Dendroidea}

Pioneering studies on the microstructure of the periderm in the Dendroidea have been made by Kozlowski $(1938,1949)$ on material dissolved from Ordovician chert nodules and sectioned for light microscopy by microtome. As shown by Kozlowski the thecal walls consist of two peridermal tissuesa fusellar tissue, constructed of semiannular or annular fusiform growth bands, and cortical tissue, a laminated, outer component. Each tissue differs in the mode of its origin. Growing thecae are made only of fusellar tissue, produced by superposition of fuselli (individual growth bands). Cortical tissue appears after some delay on the outer thecal walls, being formed by periodic and discontinuous deposition of particular layers. The cortical component of outer thecal walls is always thicker in the proximal, older thecae, than in distal ones, and is absent or very thin in the growing parts of the rhabdosome. This is inferred to be a secondary thickening of the primary thecal walls.

Although quite different in mode of formation and in appearance, both peridermal tissues are so intimately fused in the outer walls of the thecae that it is frequently impossible to trace the boundary between them on cross sections examined in the light microscope (Kozlowski, 1949:42). This is especially true for transverse cross sections. The internal walls of the thecae are, in the opinion of Kozlowski, composed only of fusellar tissue and never show a secondary thickening. This was used to support Kozlowski's (1949, 1966) interpretation that the cortical tissue was secreted by an external living membrane, producing a kind of envelope which surrounded the entire outer wall of the rhabdosome and called the extrathecal membrane.

In the opinion of Kozlowski (1949) there are no essential differences in material of both fusellar and cortical tissues when examined in the light microscope. Under certain conditions (e.g., formation of transverse dissepiments between branches in Dictyonema) the growth of cortical tissue may even result in the appearance of subconical growth lines approaching the shape of fuselli (Kozlowski, 1949:42-43). Thus the cortical tissue then may be organized in a similar manner to that in fusellar tissue.

The same histological pattern of periderm has been described in the Tuboidea and in certain Camaroidea. In some camaroids, however, the cortical tissue is indistinct or replaced by a peculiar "extracamaral tissue" of fusellar aspect (Kozlowski, 1949). It was believed that in the Graptoloidea the structure of the thecal wall was essentially comparable with that in dendroids, with perhaps a lesser amount of cortical tissue. A distinct secondary thickening of the outer thecal wall, as much as to obscure completely the underlying fusellar tissue, was considered as evidence for the existence of an outer cortical tissue in graptoloids. The investigations of microtome sections in the light microscope proved inadequate for a safe discrimi- 
nation between the fusellar and cortical components, but recognition of the latter in the electron microscope has been established beyond doubt by Berry and Takagi (1970).

\section{A Terminology for Ultrastructural Features in Dendroid Periderm}

The fusellar and cortical components of the thecal walls may be easily recognized with the transmission electron microscope and appear as a highly differentiated and organized structural system (Plate 1). However, a classification of all the observed structures into either fusellar or cortical tissue is inadequate for a proper description of their electron-microscopic appearance. Two principal categories are therefore suggested here; the category of tissue, and the category of fabric. These will serve to distinguish two major levels of structural organization in the periderm. The terms tissue and fabric are used rigorously in this paper and are indispensable for a comparison of the results obtained with the light microscope (microstructure) and with the transmission electron microscope (ultrastructure). Accordingly, an understanding of these two structural categories is essential.

The term tissue, introduced by Kozlowski (1938, 1949), is retained for the larger structural systems defined from a morphogenetic point of view and, following Kozlowski, we distinguish two peridermal tissues, the fusellar tissue and the cortical tissue. As discussed above, these peridermal tissues differ in their mode of origin and in their mode of growth. These tissues are composed of different peridermal fabrics, which can be defined in terms of characteristic patterns based on the form of their unit elements and the spatial interrelations between these elements. The inner component of the periderm composed of fusellar fabric (and organized into fusellar strips) is called the fusellum (Kühne, 1955). The outer component of the periderm we will refer to as the cortex. The fabrics observed in the periderm of the dendroid graptolites can be classified as follows:

la-fusellar fabric: a material composed of slightly wavy, branched, or anastomosing unit fibrils, with no preserved ground substance. The characteristic pattern is a threedimensional, loose network or mesh due to cross connections among fibrils, which results in a spongy appearance (Plate 2). lb-cortical fabric: a material composed of straight, unbranched fibrils embedded in electron-homogeneous and discontinuously distributed ground substance, which is itself organized into rather regularly spaced transverse rods or "webs" interconnecting adjacent fibrils. The characteristic pattern is a parallel arrangement of more or less loosely packed fibrils assembled into layers or plies. The fibrils within a given layer show the same general orientation, while in neighboring layers they frequently run at some oblique or perpendicular angle. Thus cortical fabric of different layers results in an irregular grid system (Plate 2).

lc-sheet fabric: a material of electron dense, homogeneous, or very densely reticulated pellicles delimiting particular fuselli or layers. The following patterns of sheet fabric may be subdivided:

$1 c_{1}$-a single sheet with numerous vesicular cavities occuring between particular layers of cortical fabric (Plate 3: figure 1).

$1 c_{2}$ a single sheet without (or with few) vesicles (Plate 3: figure 2), occurring in or constituting the outer pellicle (external membrane of Kozlowski, 1949) of the fuselli. ${ }^{1}$

$1 c_{s}$-double or multiple sheets without vesicles, occurring in the inner lining of the thecae (Plate 3: figure 3).

ld-crassal fabric: an elcctron dense and homogeneous material, sometimes with indistinct traces of layering but usually lacking a pattern and producing a compact wall of considerable thickness. This is found so far in stolons and in internal parts of thecae, as within mother stolotheca in Acanthograptus sp. (Plate 4: figure 1). The secondary thecal walls substituting the fusellum of Mastigograptus sp. are made of similar material (Plate 4: figure 2).

Peridermal fabrics grouped into tissues are constituents of larger anatomic structures, such as thecal walls or the basal disc. They are discussed separately.

\section{Major Structural Features of Graptolite Periderm}

The la-fusellar fabric, as preserved in the fossil state, may be considered a monotypic system, being composed of units of only one kind. In the living condition, however, the presence of a certain ground substance, most probably in an unpreservable gel-like state, is very probable. Sheet fabrics (Ic) seem also monotypic, although in multiple sheets $\left(\mathrm{l}_{3}\right)$ particular pellicles are separated by some spongy material, this compound structure being here referred to as the inner lining of thecae. Cortical fabric is distinctly polytypic, being composed of two basic units, the fibrils and

${ }^{1}$ The term sheet is selected here instead of membrane to avoid possible confusion at the ultrastructural level with any unit membranes or plasma membranes. 
the ground substance (matrix), both being preserved in the fossil state.

Peridermal tissues are larger units formed by more than one fabric but showing a predominance of either a fusellar or cortical one. Fusellar tissue is composed of la-fusellar fabric as its essential component, and of sheet material forming the outer lining of fuselli. In Dictyonema sp. the formula for fusellar tissue is $1 a+1 c_{2}$, while in Acanthograptus sp. the fusellum is provided with an outer lamella composed of lb-cortical fabric, and the formula is $1 a+1 b+1 c_{2}$.

In Mastigograptus sp. the formula of the cortical tissue is $l b+l c_{1}$, while, as a result of the occurrence of fusellar fabric between particular layers of cortical tissue as lenses or intercalations, this formula for Acanthograptus sp. and Dictyonema sp. is as follows: $1 b+1 c_{1}+$ occasionally la. Tissues are thus heterogeneous as regards fabric composition.

\section{The Fusellar Tissue}

As defined by Kozlowski $(1938,1949)$ this is a tissue composed in dendroids of numerous fuselli placed in the theca according to bilateral symmetry. Fuselli are joined to each other with their interfusellar sutures, visible on bleached and transparent specimens through overlying cortical tissue as distinct lines. Oblique sutures of superimposed fuselli form ventral and dorsal zigzag sutures (Kozlowski, 1949, fig. 5, A-B). Cross sections of fuselli examined in the light microscope show that the body of each fusellus is made of a delicate, structureless, and transparent substance covered by a pellicle produced by a denser and darker material, the external membrane of the fusellus. The internal substance at the base of a given fusellus rests immediately on the external membrane of the underlying fusellus (Kozlowski, 1949:40-41, pl. IV: figs. 1-4).

The observations made by Kozlowski are fully confirmed by our ultrastructural studies on two dendroid graptolites. The delicate, transparent, and optically structureless substance in the bodies of fuselli has been identified as la-fusellar fabric, as previously defined. The outer pellicle of the fusellus is identified as a single sheet fabric with few or no vesicles $\left(l c_{2}\right)$. The fusellar material of the bodies of the fuselli rests, as also suggested by Kozlowski, immediately on the outer sheet of the preceding fusellus, the base of the next fusellus overlapping the top of the preceding one (Plate 5).

From the structural point of view the fusellar tissue may be defined as fusellar fabric organized into fusellar bands, and fully enclosed by their outer pellicle made of sheet fabric. Longitudinal sections, crossing the boundaries of numerous fuselli, are critical for the discrimination between fusellar fabric organized into fusellar tissue, and the occasional intercalations of the same fabric within the cortical tissue. At the ultrastructure level there is no difficulty, however, in distinguishing the fusellar tissue in transverse sections, since the fusellar fabric is placed between the cortex and the inner lining. This is confirmed by transverse sections through zigzag sutures, situated in the plane of bilateral symmetry of the thecae, and therefore showing distinct fusellar boundaries (Plate 1).

While in Dictyonema sp. fusellar tissue is composed only of fusellar fabric and the outer sheets of fuselli, its structure is somewhat more complex in Acanthograptus sp. Although the fabric in the bodies of fuselli is the same, there is a distinct difference in the structure of the outer part of the fuselli, there being in Acanthograptus sp. an outer lamella (Plate 6), in addition to an outer pellicle formed by the sheet fabric. The outer lamella lies immediately internally from the outer pellicle, and separates it from the body of the fusellus proper. The outer lamella is made of tightly packed fibrils, lying parallel to one another with very little matrix between the fibrils. The matrix is visible sometimes in the form of interconnecting rods. The outer lamella of the fuselli, fused with the cortical components of the thecal walls, does not differ from adjacent layers of cortical fabric and may be considered as a cortical component within the fuselli. In having an outer lamella with ordered fibrils, in contrast to the adjacent fusellar material of the fusellus body, Acanthograptus sp. approaches the graptoloids, where an outer lamella is also recognized. In contrast to the well-developed outer lamella, the outer pellicle of the fuselli in Acanthograptus sp. is very faint and at the top of fuselli often barely discernible (Plate 6). As a result of the presence of an outer lamella of the fuselli, made of the cortical fabric, the fusellar tissue in Acan- 
thograptus sp. is more heterogeneous as compared with the same tissue in Dictyonema sp.

In Mastigograptus sp. the fusellar tissue shows an unusual development-being either absent over large areas, or showing an irregular distribution within the walls of the rhabdosome. Some details on the distribution and structure of fusellar tissue, with an attempt at an explanation, are presented in the section on the composition of thecal walls.

Kozlowski (1938, 1949) introduced a morphogenetic implication into the meaning of fusellar tissue by considering this tissue the only component of the primary thecal walls. The cortical tissue would be deposited over the fusellar walls of the thecae after a certain delay. This point cannot be verified by the dendroid material described here but finds convincing support in our observations on the Graptoloidea (in preparation). It is possible, however, to estimate the time of deposition of the cortex in the dendroids, which seems to occur very early.

\section{The Cortical Tissue}

As defined morphogenetically by Kozlowski $(1938,1949)$, the cortical tissue is formed secondarily over the outer surface of the primary thecal walls, which are made of a fusellar component only. It is composed of numerous layers, most frequently showing an alternation of lighter and darker, sometimes black, layers. Examined under the light microscope, particular layers seem more or less regular, undulated, and tapering. Individual layers may be delimited distinctly, or the cortical tissue may form a still layered but rather compact mass (Kozlowski, 1949, pl. IV: figs. 8, 10).

From electron microscope studies, the cortical tissue might be defined as a system composed essentially of cortical fabric delimited by a number of sheet fabrics to form numerous layers, and deposited over the fusellar component of the thecal walls. On the whole, the cortical tissue in Dictyonema sp. and Mastigograptus sp. seems rather loose as compared with its compactness in Acanthograptus sp. The outer part of the cortex in the latter is characterized by numerous sheets, densely deposited one over another. No fibrils are recognized in the material separating adjacent sheets, and commonly there is very little material between them. In each case the cortical tissue is to some extent "porous": in Dictyonema sp. as a result of the presence of intrasheet vesicles, while in Acanthograptus sp. and Mastigograptus sp. also, as a result of numerous, randomly dispersed interfibrillar vesicles. These are sometimes round, sometimes droplet- or fissure-like, and give the cortical tissue a peculiar appearance (Plate 11). Most of them have their own pellicle, probably primary, although obscure in nature. A few, however, are lacking their own pellicle and may be preservational features secondarily formed as a result of fossilization.

Within particular layers of the cortical tissue laid down on the outer thecal walls in Dictyonema sp., intercalations or lenses of spongy material have been found (Plate 7: figure 1). This material seems to be "pseudofusellar," being composed of fibrils that are on the average smaller than the fusellar fibrils and which represent an accumulation of ground substance, for there are numerous interconnecting rods devoid of cortical fibrils, showing a spongy appearance.

In Acanthograptus sp., true fusellar fabric, indistinguishable from that in fuselli, has been found as frequent intercalations between layers of the cortical tissue in the outer wall (Plate 7: figure 2). Similar intercalations were recognized in the cortical component of inner thecal walls. No such intercalations have yet been found in the cortex of Mastigograptus sp.

Like the fusellar tissue, cortical tissue is a heterogeneous system built of different fabrics. There is a substantial predominance of cortical and sheet fabric, although the occurrence of fusellar fabric is sporadically seen. Secondary deposition of cortical fabric over the fusellar walls of thecae cannot be proved on the material described here, but is clearly seen in observations on the graptoloidea (in preparation), and by numerous observations of other authors. The data here indicate, however, that at least in certain dendroids, the cortical fabric has been deposited very early after formation of the fusellar wall of the thecae.

\section{The la-Fusellar Fabric}

This fabric is recognized in bodies of fuselli (in fusellar tissue), and sporadically also as intercala- 
tions, lenses, or patches within a particular layer of cortical tissue. The material of fusellar fabric consists of nonbanded fibrils, always loosely packed, and branched or anastomosing irregularly, sometimes straight, but usually somewhat wavy (Plate 5). They appear as solid cylinders usually without traces of internal structure. Their average diameter approaches $600 \AA$. The spatial distribution of fusellar fibrils is characterized by their frequent three-dimensional interconnections, branching and anastomosing of neighboring fibrils. This results in a meshy, or "spongy" structure, particular fibrils being packed loosely but frequently interconnected. There are no indications of a preserved ground substance in the interfibrillar spaces, which appear electron-lucent. As preserved in the fossil state, fusellar fabric looks monotypic, the fusellar fibrils being the only structural units of the fabric. Only occasionally, at the top of fuselli close to the outer pellicle in Dictyonema sp., has the presence of a certain amount of interfibrillar matrix been observed, and a similar phenomenon has been recognized in the outer layer of the fuselli in Acan. thograptus sp. But in a majority of cases, the proportion of this ground substance is so insignificant that true fusellar fabric may be classified as essentially monotypic, being composed of units of the same kind (Waddington, 1962).

\section{The lb-Cortical Fabric}

This is the fabric predominating in the cortical tissue and its derivatives. The fabric is composed of units of two kinds: (a) the cortical fibrils, and (b) the ground substance or matrix, partly filling the interfibrillar spaces. Cortical fabric may be, therefore, classified as a polytypic system (Waddington, 1962).

The cortical fibrils are, in Dictyonema sp. and Mastigograptus sp., coarser than the corresponding fusellar fibrils. In Acanthograptus sp., however, they have approximately the same diameter as the fusellar fibrils, and in Dictyonema sp. are provided with a distinct, central, lucent core. The fibrils are solid in Acanthograptus sp. and Mastigograptus sp. The average diameters of the cortical fibrils are as follows: Dictyonema sp., $0.2 \mu \mathrm{m}$, Mastigograptus sp., $0.15 \mu \mathrm{m}$, Acanthograptus sp., $0.1 \mu \mathrm{m}$, and appear to be rather stable for each form studied. There is no distinct change in diam- eter within a particular layer or between different layers of the cortical fabric (Plate 8).

The outline of fibrils oriented more or less perpendicularly to the surface of the sections is circular, or slightly oval. Cortical fibrils are more closely packed than in fusellar fabric, but in a majority of cases are separated from each other by interfibrillar spaces. Dictyonema sp. and Mas. tigograptus sp. have a comparatively loose cortical fabric as compared with Acanthograptus sp., where it is rather compact (Plates 9, 10). The cortical fabric in Acanthograptus sp. seems very homogeneous in some views, but in other sections the presence of distinct fibrils showing the characteristic pattern can be recognized (Plate 9: figure 2). In Acanthograptus sp., and also occasionally in Dictyonema sp., the fibrils are sometimes tightly adpressed to one another, resulting in a tendency toward angular outline of their cross sections (Plate 9: figure 2, Plate 8: figure 1). The lack of suitably oriented sections does not allow for an estimate to be made of the total length of the cortical fibrils.

In Dictyonema sp. the ground substance or matrix is less electron dense than the fibrils, and appears as a rather homogeneous mass partly filling the interfibrillar spaces. In Mastigograptus sp. and in Acanthograptus sp. the difference in electron density between fibrils and matrix is less distinct. The ground substance is rather abundant in Dictyonema sp. and in Mastigograptus sp. It is discontinuously distributed and organized into numerous interconnecting rods by which adjacent fibrils are connected (Plate 9: figures 1, 3). In certain cases, these interconnecting elements are transformed into a kind of wider network or "web," or are connected by closely associated "double" rods. The usual number of these interconnecting rods is some 5-6 in Dictyonema sp. and some 6-9 in Mastigograptus sp., around a particular fibril examined on its transverse sections. In Acanthograptus sp., as a result of the dense packing of fibrils, its amount seems restricted (Plate 9: figure 2).

Longitudinal sections reveal that adjacent fibrils lying parallel to each other are interconnected for their entire length by numerous interconnecting rods, arranged one under another in longitudinal rows (Plate 10). In Dictyonema sp. these interconnecting rods show a rather regular spacing of some 
$800 \AA$, as measured by use of standard-size polystyrene spheres (Towe and Urbanek, 1972). This spacing is frequent but irregular in Mastigograptus sp., and rather infrequent and irregular in Acanthograptus sp. (Plate 10: figures 2, 3). In Dictyonema sp. interconnecting rods lie on both sides of an individual fibril, and when examined in longitudinal sections are seen to be usually opposite each other and at the same level. Less frequently they are somewhat shifted to produce an alternate pattern. These relations may change along a single fibril (Plate 10: figure 1). The ground substance of the cortical fabric seems continuous with the sheet fabric which separates particular layers or plies. The highly characteristic pattern of the cortical fabric is produced by assembling bundles of uniformly oriented fibrils into separate layers, each delimited by sheet fabric. Fibrils in adjacent layers are usually differently oriented, but not necessarily orthogonally to each other. Oblique orientation or, in some cases, even multiple repetition of layers with the same orientation of fibrils are much more common. Fibril systems of different layers thus follow a rather irregular, nonorthogonal grid pattern. In Dictyonema sp. the number of fibrils superimposed one over another to form a particular layer is usually 5-6, although smaller numbers are also recognized. This number is some 6-10 fibrils in Mastigograptus sp. and 6-8 in Acanthograptus sp. Fibrils assembled into a given layer are not, however, superimposed along straight lines, but more or less irregularly displaced within the thickness of the layer. Sometimes the distribution of fibrils within a given layer is distinctly uneven, the fibrils being gathered into rough bundles, separated transversely by a greater accumulation of ground substance to produce a superficial resemblance to Conheim fields in muscle cells (Plate 11: figure 1).

\section{The lc-Sheet Fabrics}

As defined above, this is a fabric which forms electron dense, rather homogeneous, or densely reticulated pellicles, marking surfaces of certain growth discontinuities in both fusellar and cortical tissues.

Of the three categories of recognized sheet structures $\left(1 c_{1}-l c_{3}\right)$, the most instructive is that which occurs between the particular layers of cortical material $\left(l c_{1}\right)$. Examined at lower magnifications these sheets appear as dark, homogeneous, and continuous lines, associated with rather numerous vesicles (Plate 8: figure 1). In Dictyonema sp. these vesicles are distinctly within the sheets and are slightly elongated laterally, their dimensions being the same on transverse sections. Studied at higher magnification and at higher $\mathrm{kV}$, the substance forming the sheet seems continuous with the ground substance of cortical fabric (Plate 9: figure 1). Its higher density as compared with the matrix of cortical fabric might be a result of the greater thickness and continuous nature of sheet fabric. Although postmortem artifacts are a possibility, the smooth margins and continuous thin walls between closely placed intrasheet vesicles seem to provide evidence for their primary nature. Their biological nature is difficult to explain. They are too small to consider as embedded traces of cells. If not artifacts, a more probable explanation is that they were local accumulations of cellular secretions of a liquid or gaseous nature.

Sheet fabric of the $l c_{1}$ type remains rather homogeneous even when examined at higher magnifications in Dictyonema sp. and in Acanthograptus sp., while in Mastigograptus sp. it resembles a tight wool felt, being a condensation of some reticulate material rather than a single sheet (Plate 9: figure 3).

While the majority of sheets delimiting cortical fabric are single, the presence of double or even multiple sheets was occasionally observed. Part of the double sheets were formed as a result of the tapering of layers of cortical fabric and the merging of their upper and lower sheets (Plate 11: figure 1). Formation of multiple sheets is also conceivably a result of some repetition of secretionary processes. This seems to be the case in the outer part of the cortex in Acanthograptus sp., which is composed almost entirely of such sheets (Plate 12: figure 1). Occasionally in Dictyonema sp. a multiple cleposition of sheet fabric, accompanied by mumerous intrasheet vesicles, has also been noted in the outer part of the cortex (Plate 11: figure 2).

In Mastigograptus sp., and to a lesser extent in Acanthograptus sp., only a lew intrasheet vesicles occur. The majority of them are only adpressed to one side of the sheet (Plate 12: figure 2). In Mastigograptus sp. these vesicles are in most cases 
occurring toward the outer surface, and located at the bottom of the succeeding layer.

Sheets between fuselli $\left(l c_{2}\right)$, or their outer membranes in Kozlowski's terminology (1949), seem less homogeneous and less smooth than those within the cortical fabric. In some cases they appear as condensations of fusellar fibrils rather than single sheets (Plate 3: figure 2; Plate 5: figure 2). However, more homogeneous, thin lines, similar to the sheets of $l c_{1}$ type, may occur in the same specimen. Intrasheet vesicles are present but are less frequent than in the sheets of cortical fabric.

The third kind of sheet fabric $\left(l_{3}\right)$ is observed in the internal lining of thecae (Plate 1, Plate 3: figure 3). It consists of multiple sheets laid down on the internal surface of the fusellum. These are continuous over a number of neighboring fuselli, and were deposited secondarily over the primary, outer lining of particular fuselli. Multiple sheets in Diclyonema sp. consist of electron dense pellicles, divided by more lucent material of spongy appearance, spread between adjacent sheets. This intersheet spongy material resembles either fusellar fibrils, or "pseudofusellar" material. Intersheet vesicles, although they occur in multiple sheets of the inner lining, are very rare. In Mastigograptus sp. the inner lining is substituted by a rather thick, homogeneous, and clense layer, deposited over or substituting for the fusellum.

\section{Composition of Cortical and Fusellar Fabrics}

There has been a widespread belief that the graptolite periderm is made of chitin or a "chitinoid" substance (reviewed in Kozlowski, 1966). Although Kraft (1926) was not able to obtain a positive chitosan reaction, he nevertheless suggested the presence of chitin on the basis of other nonspecific staining tests. Support for a chitinous nature in dendroids was given by Manskaya and Drozdova (1962) after they reported the presence of glucosamine ancl several amino acids on chromatograms of dendroid hydrolysates. On the other hand, later workers (Foucart, Bricteux-Grégoire, Jeuniaux, and Florkin, 1965; Foucart and Jeuniaux, 1966) using graptoloid species were unable to detect glucosamine in their hydrolysates, although they, too, found significant quantities of amino acids. Our own data on the dendroid Dic- tyonema sp. also failed to detect glucosamine (Towe and Urbanek, 1972). Inasmuch as the effects of diagenesis on proteins and chitin or cellulose are imperfectly understood the original chemical composition of the graptolites remains in doubt. The absence of glucosamine in hydrolysates can only be interpreted to mean that the graptolite periderm is not now chitinous. The proteinaceous aspects are equally difficult to discern from amino acid analyses alone, not only because of the severe problems of diagenesis but also because of possible contamination (see Hare, 1965, 1969).

Towe and Urbanek (1972) have pointed out a striking similarity between the cortical fabric of Dictyonema sp. and the extracellular plies of collagen recognized in connective tissues of many Recent organisms. In the light of these considerations, cortical fibrils may be considered a collagenlike material and the matrix associated with these fibrils can be compared with a polysaccharideprotein complex. This interpretation is tenable also for the cortical fabric recognized in Acanthograptus sp. and Mastigograptus sp., since the differences in physical organization of the fabrics lie within the range found for collagen tissues in different groups of the animal kingdom.

As seen in Table 1, the three forms studied might be grouped into a series showing ordered changes in the structure of cortical fabric, of course without any correlation regarding their systematic and phylogenetic position. The dendroid Dictyonema sp. and the aberrant benthonic graptolite of unknown systematic position, Mastigograptus sp., show cortical fabrics strongly resembling the extracellular plies of collagen, while the structural pattern found in the other dendroid, Acanthograptus sp., is to a lesser degree similar.

The nature of fusellar material is somewhat more obscure. Towe and Urbanek (1972) were inclined to think that it is probably also composed of collagen-like fibrils, but were unable to present cogent arguments in favor of this opinion because of the lack of any diagnostic features. Both fabrics show rather substantial clifferences as discussed earlier. Fusellar fibrils are branched or anastomosing and irregularly interconnected, while cortical fibrils are unbranched and arranged in an orderly manner. Normal collagen consists of unbranched fibrils, but in certain circumstances they may branch to form rather thick fibers (as in spongin 
TABLE 1.-Comparison of the cortical fabric

\begin{tabular}{|c|c|c|c|}
\hline Cortical fabric & Dictyonema sp. & Mastigograptus sp. & Acanthograptus sp. \\
\hline & Fibrils cored & Fibrils uncored & $\begin{array}{l}\text { Fibrils uncored } \\
\text { ("solid") }\end{array}$ \\
\hline \multirow[t]{2}{*}{$\begin{array}{l}\text { Fibrils } \\
\text { and their } \\
\text { arrangement }\end{array}$} & $\begin{array}{l}\text { Rather loosely } \\
\text { packed }\end{array}$ & $\begin{array}{l}\text { Rather loosely } \\
\text { packed }\end{array}$ & $\begin{array}{l}\text { Rather tightly } \\
\text { packed }\end{array}$ \\
\hline & $\begin{array}{l}\text { No inter- } \\
\text { fibrillar vesicles }\end{array}$ & $\begin{array}{l}\text { Numerous inter- } \\
\text { fibrillar vesicles }\end{array}$ & $\begin{array}{l}\text { Numerous inter- } \\
\text { fibrillar vesicles }\end{array}$ \\
\hline $\begin{array}{l}\text { Matrix } \\
\text { and its } \\
\text { organization }\end{array}$ & $\begin{array}{l}\text { Abundant, with } \\
\text { rods rather } \\
\text { frequently and } \\
\text { regularly spaced }\end{array}$ & $\begin{array}{l}\text { Abundant, with } \\
\text { rods rather } \\
\text { frequently but } \\
\text { irregularly spaced }\end{array}$ & $\begin{array}{l}\text { Scanty, with } \\
\text { rods infrequently } \\
\text { and irregularly } \\
\text { spaced }\end{array}$ \\
\hline
\end{tabular}

B, Gross and Piez, 1960) anastomosing fibrils (as in periodontium of mammals, Shackleford, 1971). Thus the distinct differences in physical organization of the cortical and fusellar fibrils does not exclude the possibility that they are closely related fibrous substances. As an example, collagen material is quite differently organized in the Bowman membrane of the eye (basal lamina of the corneal epithelium, which consists of an irregular mesh of thin fibrils) and in the immediately subjacent cornea proper, where it produces regular orthogonal plies made of much thicker fibrils (Jakus, 1964). These differences strongly resemble those between the fusellar and cortical fabric. Moreover, the observed intergradations between these fabrics within graptolite periderm seem to indicate that they represent two types of physical organization of the same, or very similar, fibrous material from the collagen group. In Dictyonema sp. a gradual transition from typical fusellar to typical cortical fabric may be occasionally traced within a single fusellus (Plate 13: figure 1). At the bottom of the fusellus both the fibrils and their pattern are typically fusellar, while toward the top there is an increase of coarser fibrils, showing a certain amount of matrix organized into interconnecting rods. Close to the upper limit of the fusellus the fibrils and their pattern resemble very much the typical cortical fabric, showing an almost parallel arrangement and numerous interconnections of matrix.

In Acanthograptus sp. each fusellus is provided peripherally with a dense outer lamella, showing fibrils with a definite cortical arrangement, but with scanty matrix between them, as is typical for the cortical fabric in this form. Instead of a gradual transition as in Dictyonema sp., the fuselli of Acan. thograptus sp. demonstrate a rather sharp demarcation from fusellar into cortical fabric (Plate 6: figure 1). In both cases, however, there is a change from the secretion of fusellar fabric into secretion of cortical fabric within a single secretionary unit. Both in Dictyonema sp. and in Acanthograptus sp., it is occasionally possible to trace a single fibril of true spongy fusellar fabric transitionally into the ordered fibril complex indistinguishable from cortical fabric (Plate 6: figure 2). A similar phenomenon is illustrated by the shift from secretion of the cortical to secretion of the fusellar fabric in the fusellar intercalations of cortical tissue. Here, however, both fabrics are as separate layers, which may indicate that they were formed in successive secretionary phases. These observations all seem to suggest a rather intimate relationship between the fusellar and cortical fabrics, each being secreted almost simultaneously during a single secretionary phase, or showing an easy shift from the secretion of one to the secretion of the other. These relations may be best explained as an expression of the essential biochemical similarity of both peridermal materials.

On the other hand there are some data to indicate that the same cells can in certain circumstances synthesize two different fibrous proteins such as keratin and collagen or even such different. substances as $\beta$-chitin and collagen. In epithelial cells secreting keratin and collagen simultaneously, the former accumulates intracellularly while the latter is extruded extracellularly (Porter, 1964). The secretion of both $\beta$-chitin and collagen occurs at 
different poles of epithelial cells (Rudall, 1955). The extracellular secretion of two biochemically different fibrous components simultaneously by the same cells, at the same place, would seem to be the exception rather than the rule and therefore less likely in the case of the graptolites.

If, however, cortical and fusellar fibrils are similar or identical in their biochemical nature, why are they so different in appearance? The different physical organization of cortical and fusellar fibrils may result from the interrelations between the fibrils and the inferred carbohydrate-protein complex. The opinion that size, orientation, and register of collagen fibrils can be determined by a carbohydrate-protein matrix has been expressed many times. In the extracellular "plywood" systems of collagen fibrils, this matrix is believed to be responsible for the ordered organization of protein fibrils (Matthews, 1965). The unpreserved matrix presumed in fusellar fabric must have differed considerably from that preserved in cortical fabric. The same fibrous protein might be randomly oriented and randomly aggregated in one matrix, and highly ordered in another.

\section{Comparison with Previous Results}

The published figures in Kraatz's paper (1964, Abb. 1, a-b) are not photographs. They are strongly diagrammatical and it is difficult to compare them with our observations on Dictyonema sp., althougl Kraatz's discrimination between the structure of cortical and fusellar tissue seems in general correct. The different kinds of aggregate discs, filaments, and other irregular material recognized by Kraatz within the thecal wall of Dictyonema and some graptoloids (Kraatz informal report, 1968 Ludlow Research Group, Bulletin 15) cannot be readily compared with either the results obtained by Berry and Takagi (1970, 1971) or with our observations on dendroid and graptoloid graptolites. The aggregates described by Kraatz may result either from an unsatisfactory state of preservation of the material studied or from peculiarities of the technique applied.

Berry and Takagi $(1970,1971)$ concluded that the cortical layer in two species of graptoloids appears to be composed of two alternating sublayers. These are a mesh sublayer composed of fibers that cross randomly, and a fabric sublayer with two sets of fibers oriented normal to each other. The presence of a mesh or a regularly alternating component of cortical tissue is not supported by our studies on either dendroid or graptoloid graptolites, although some meshwork material has been found occasionally within cortical deposits. The presence of sets of fibers oriented perpendicularly or obliquely to each other is supported by our observations, these sets, however, being packed into bundles uniformly oriented within particular layers. In our data the image of a double set of fibers, each arranged uniformly in one plane and mutually crossing each other, can be produced at the point where two plies of cortical fabric are fused by sheet fabric. This situation, frequently figured by Berry and Takagi, might be explained as the result of a mechanical preference in the process of peeling small pieces of the cortex used by these authors for their examination with the electron microscope. The texture of fusellar tissue (not subject to such preference) has been correctly described by Berry and Takagi $(1970,1971)$ as a mesh.

Rickards, Hyde, and Krinsley (1971), on the basis of an examination of monograptid periderm with the scanning electron microscope, suggested that the cortex is composed "of successive layers of coalescing granules, the greater coalescence being in deeper and earlier deposited layers." They attempted to distinguish a difference in ultrastructure between the cortical and fusellar tissue and described a somewhat enigmatic lamination on the outer surface of the fusellar layer arranged normal to boundaries of particular fuselli and continuous across a number of them. They emphasized correctly the smooth, inner surface of the fuselli, but their other observations are difficult to correlate with data obtained with the transmission electron microscope. This emphasizes the general inadequacy of lower resolution scanning microscope techniques not only for the recognization of internal structural patterns or sheet fabric in such material, but even for the safe discrimination between the major constituents of graptolite periderm-the cortical and fusellar tissue.

\section{Ultrastructural Anatomy of the Thecal Walls}

For the purpose of the present study, which is not intended to be a complete detailed submicro- 
scopic anatomy of the entire dendroid rhabdosome, the anatomical constituents of the stipe were subdivided into two categories: (a) outer thecal walls, placed peripherally and subjacent to cortex, and (b) inner thecal walls separating the cavities of adjacent thecae.

The absence of cortical material from the internal walls of rhabdosomes in dendroid graptolites, suggested by Kozlowski (1949) and indicated by his serial microtome sections of dendroids, has been proven to be correct on newly made microtome sections of Dendrograptus regularis Kozlow. ski, examined with the light microscope. This absence of cortical derivatives in internal thecal walls in Dendroidea is, however, not an absolute one, because it is indicated by present observations on Dictyonema sp. and to a lesser extent also in Acanthograptus sp.

In Dictyonema sp. the outer thecal walls are invariably composed (going from the outside) of: (1) the coating of the cortical tissue (cortex), (2) the layer of the fusellar tissue (fusellum), and of (3) the inner lining of the thecae. This last is formed as a result of deposition of multiple sheet

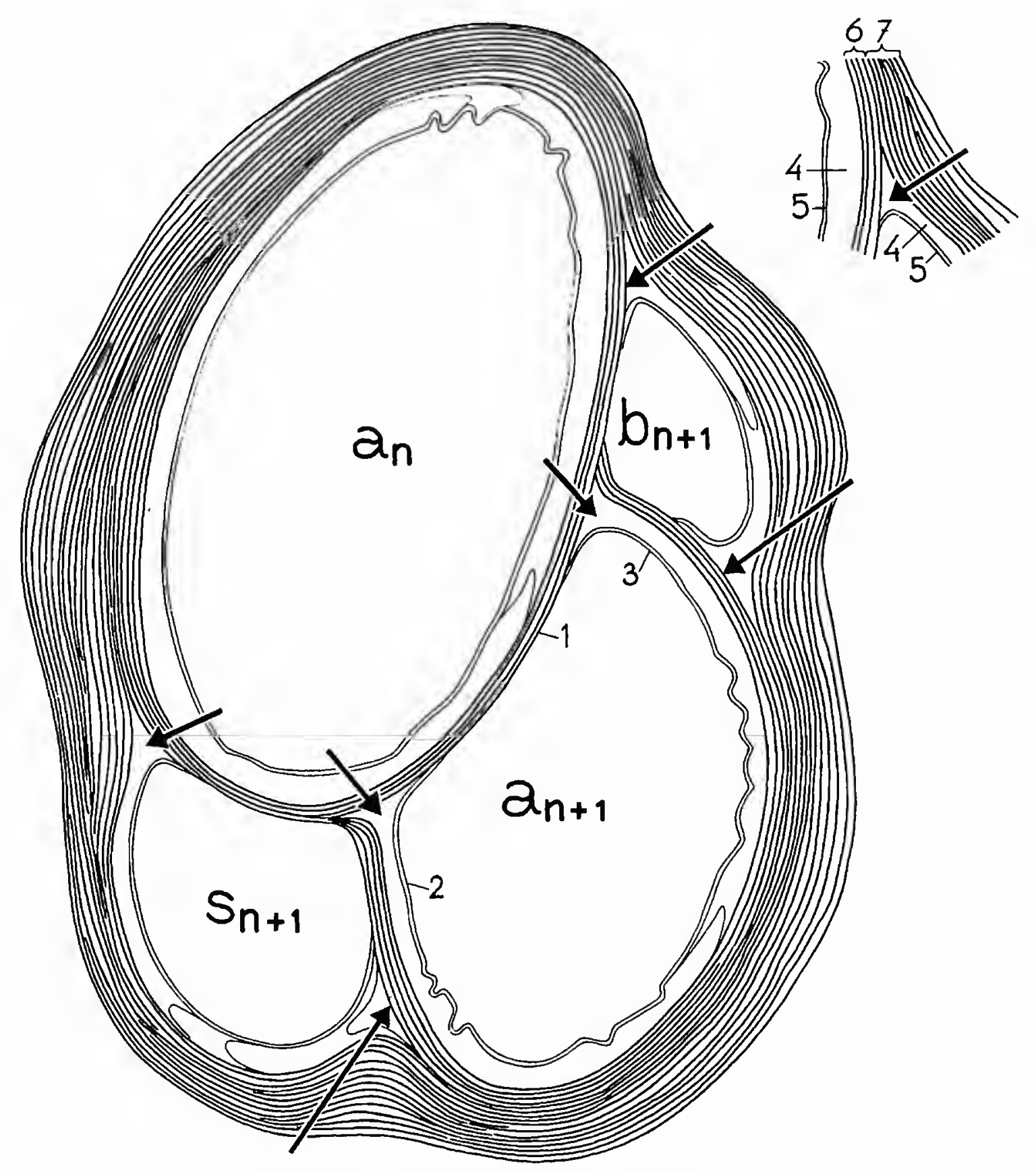

Ficure 1.-Diagrammatic: transwerse section of a stipe in Dictyonema sp., showing the main components of the thecal walls. Autotheca $\left(a_{n}\right)$ of preceding triad, $a_{n+1}, b_{n+1}, s_{n+1}$, auto-, bi- and stolotheca of succeeding triad, 1, 2, 3 inner thecal walls incntioned in text, 4 fusellar tissuc, 5 inner lining, 6 autocortex, 7 rhabdocortex. The arrows indicate points of fusion of the thecal walls. 
fabric $\left(1 c_{3}\right)$ over the inner surface of these walls. This surface is therefore characteristically smoothed except for a number of peculiar infoldings, whose origin and significance remain obscure (Plate 1).

The structure of the inner thecal walls in Dictyonema sp. is more variable. Each inner thecal wall is common to two adjacent thecae (see diagram, Figure 1), but in spite of this they have an asymmetric structure. For instance the inner thecal wall separating thecae identified as autothecae $a_{n}$ and $a_{n+1}$ has its fusellar component covered at the side of $a_{n}$ by an inner lining, but on the side of $a_{n+1}$ by a cortical deposit. The structure of this wall is in this sense asymmetric and resembles an outer wall.

Most surprising, however, is the presence of a distinct cortical fabric laid down in the inner walls of the thecae (Plate 14). The classical scheme of dendroid structure suggested by Kozlowski (1949) presumed a secondary thickening of thecal walls only through deposition of cortical fabric over the outer surface of the thecae and around the aperture. These somewhat paradoxical facts may be readily explained if we remember the growth relationships at the terminal triad in a dendroid rhabdosome (Kozlowski, 1949). The growth of the lateral thecae of each triad (bitheca, stolotheca) is somewhat delayed when compared with the growth of its middle component (autotheca). A given autotheca $a_{n+1}$ constructs its thecal walls by growing partially along autotheca $\left(a_{n}\right)$ of the preceding triad (wall at 1 on Figure 1). The lateral thecae of the triad in question $\left(s_{n+1}\right.$, $\left.b_{n+1}\right)$ subsequently use, in the same way, the walls of autotheca $a_{n+1}$ (walls 2 and 3 on Figure 1). But at the point of fusion of the thecal walls, the corresponding zooids behave somewhat specially, producing a local reinforcement of the fusellar component (arrows in Figure 1). The diagram presents the structure of the thecal walls in a transversal section in Dictyonema sp.

This explanation accounts for the asymmetry in structure of the inner wall since each "inner" wall is primarily an outer wall, becoming "inner" as a result of overgrowth. The classical view of Kozlowski (1949) of an exclusively external deposition of cortical fabric is essentially tenable for Dictyonema sp., if we presume that a certain amount of this deposit is formed soon after the origin of each autotheca, and is later followed by the formation of a common cortical coating around the branch. The diagram on Figure 1 emphasizes this subdivision of the cortex into an autocortex, connected with outer walls of particular autothecae, and a rhabdocortex, producing a common envelope around all thecae of the rhabdosome.

The model of formation of the thecal walls, suggested above, explains another striking fact, namely the reversal of the components of the inner wall, shared by the same theca with different neighboring thecae. The wall separating theca autotheca $a_{n+1}$ from the autotheca of the preceding triad $a_{n}$ (wall 1 on Figure l), and from thecae somewhat arbitrarily designated here as stolotheca $s_{n+1}$ (wall 2 on Figure 1) and bitheca $b_{u+1}$ (wall 3 on Figure l) is composed successively of the following layers, starting from the cavity of theca $a_{n+1}$ :

Wall (1)_cortical_fusellar_-inner lining

Wall (2)_inner lining_fusellar_cortical

Wall (3)_inner lining-fusellar-cortical

The reversed order of components in wall $\mathrm{l}$ as compared with those in walls 2 and 3 is due to their formation by different zooids. Specifically, wall 1 has been secreted by autozooid an before the origin of the autotheca of the next triad $a_{n+1}$ has taken place. The walls 2 and 3 were secreted by the autozooid $a_{n+1}$, which preceded in turn the growth of lateral thecae of the same triad $\left(\mathrm{s}_{\mathrm{n}+1}\right.$, $\left.b_{n+1}\right)$. These walls (2 and 3) were overgrown later by the last named thecae.

At the point of fusion of the thecae (e.g., wall 2) with the wall proper of stolotheca $s_{n+1}$, and wall 3 with the wall proper of bitheca $b_{n+1}$, the corresponding zooids produced an excessive amount of fusellar material, thus forming a triangular reinforcement as mentioned above. At such places the succession of components counted from the cavity of the theca $a_{n+1}$ is as follows:

$$
\text { inner lining-fusellar_cortical [fusellar_inner lining] }
$$

The components in brackets are the result of an excessive deposition of fusellum at places of thecal fusion.

A different picture of the structure of the thecal walls is presented by Acanthograptus sp. The outer thecal walls differ from those in Dictyonema sp. primarily as regards their fusellar component. It is thin, discontinuous over large areas, or even 
entirely lacking (Plate 15). This reduced appearance of the fusellar part of the outer thecal wall could be the result of a secondary decomposition due to preservation or even some resorption during life but in any case, when completely developed, the outer thecal wall in Acanthograptus sp. is composed of: (1) a heavy, multilayered outer coating of cortex, (2) a thin layer of fusellar tissue, (3) a thin internal cortical fabric composed of a few layers or even only one layer facing the thecal cavity (Plate 15). Some layers of this internal cortical coating probably originate through the accumulation of the overlapping outer lamellae of a number of neighboring fuselli (Plate 16). The normal degree of overlap of the adjacent fuselli is half, or less, of their length, the outer lamella of the next fusellus overlaps the preceding one and tapers gradually (Plate 16). In certain cases a greater overlap may result in embracing by an outer lamella of one or more fuselli, producing in this way a coating composed of 2-3 layers (Plate 16). Although such formation of the internal cortical coating on the inner thecal walls differs from the mode of deposition of cortex, its fabric is structurally cortical. However, formation of layered cortical fabric, independently of the outer lamellae of the adjacent fuselli, seems far more common. A number of cortical intercalations observed within internal thecal walls most probably are formed in this way as genuine cortical layers, although a certain share of cortical fabric formed through an overlapping of the outer lamellae of adjacent fuselli cannot be excluded (Plate 16). A separate inner lining made of multiple sheet fabric (so distinct in Dictyonema sp.) has not been observed in Acanthograptus sp.

Some inner thecal walls in Acanthograptus sp. contain a middle fusellar component, usually well developed in contrast to that in the outer walls, and covered on both sides by cortical components. One of these (outer) is usually distinctly thicker than the other (Plate 17: figure 1). In this respect the structure of the inner thecal walls is asymmetric, even though a cortical deposit is present on both surfaces of each wall. The thicker coating is multilayered, and it may fuse in places with a common cortical envelope of the stipe (Plate 17: figure 2). The thinner cortical deposit on the inner walls may be composed of 1-3 layers of cortical fabric. On some inner thecal walls both cortical deposits are indistinct or absent.

Thecal walls in the free parts of autothecae, stretching in Acanthograptus sp. as separate "twigs," are rather similar structurally to the inner thecal walls (Plate 18). The fusellar component is well developed, and covered from the outside by a substantial cortical deposit, thicker at the base and gradually decreasing toward the aperture. Although thinner than on the outer side, this deposit continues around the aperture, deep into the "twig" (Plate 18). The apertural margin is provided with a multilayered cortical deposit. In view of the presence of cortical fabric deep inside the "twigs" and on the inner surfaces of some thecae, the classical scheme of cortical tissue formation in dendroids suggested by Kozlowski (1949) (and with certain modifications tenable for Dictyonema sp.) seems inadequate in the case of Acanthograptus sp. It appears that in some dendroids the soft tissues on the inside of the thecae were capable of formation of cortical fabric and multilayered cortical tissue. Thus Acanthograptus sp. represents a combination of conditions-some of its inner thecal walls being made after the pattern recognized in our Dictyonema sp. (presence of cortical components), some after the pattern established in Dendrograptus regularis (lack of cortical components) (Kozlowski, 1949). Differences in the composition of the inner thecal walls in the Dendroidea in contrast to previous views, suggest variable patterns of secretion by the corresponding tissues of the body in zooids.

In Mastigograptus sp. some sections through the branches of the stipe in specimen 1 failed to reveal distinct traces of a fusellar component in the thecal walls. The innermost part of outer thecal walls, and the entire inner wall as well, is composed of a peculiar fabric, which is rather electron dense and homogeneous, without any resolvable details except a few rather vague lamellar densities observed at certain spots (Plate 19). This crassal labric, which is not unlike stolonal material, forms a continuous layer in the outer thecal walls adjacent to the cortical component of the thecae, fused to it or separated by a narrow fissure, the latter being most probably a preservational feature. At certain places (Plate 19: figure 3) the following sequence of layers has been recognized 
starting from the thecal cavity: (a) a homogeneous, dense layer, (b) a thin layer of spongy appearance, presumably the remnants of the fusellar material, (c) pellicular layer, (d) the first, and successive layers of cortical fabric. In some cases the spongy layer (b) is indistinct and in such cases the inner part of the homogeneous layer (a) has a certain fibrous aspect. The homogeneous material in certain areas is represented by isolated blocks, whiclı result in a roughness of the inner thecal surface, which is visible even in the light microscope.

Longitudinal sections through the upper part of the "stem" (unbranched lower part of the stipe) of the same rhabdosome (specimen l) show the presence of a few erratic fuselli (Plate 20). These are limited to certain places on the outer wall, forming small patches attached to more prominent parts of the inner surface of the thecae. Such "promontories," with the top made of residual

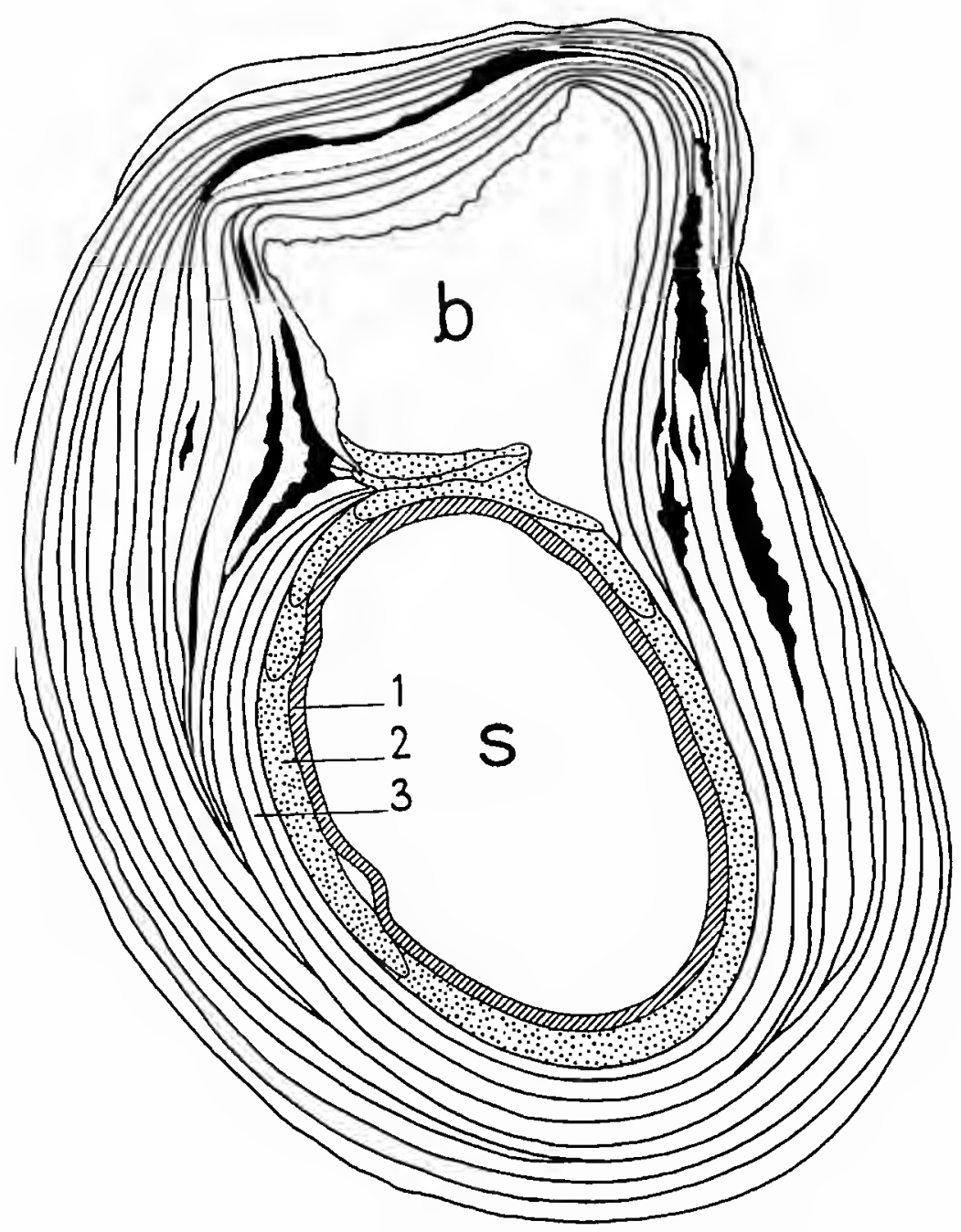

Figure 2.-Diagrammatic transverse section of the stipe in Mastigograptus sp., showing the main components of thecal walls within the stipe proper (s) and a branch (b). 1 inner layer of crassal fabric, 2 fuselli, 3 cortex. Fissures within the cortex are shown in solid black.

\section{TABLE 2.-Occurrence of fusellar tissue in Mastigograptus species}

\begin{tabular}{|c|c|c|}
\hline \multirow[b]{2}{*}{ Specimen } & \multicolumn{2}{|c|}{ Fusellar tissue } \\
\hline & in branches of rhabdosome & in stem of rhabdosome \\
\hline 1 & no traces & erratic distribution \\
\hline 2 & normally present & no traces \\
\hline
\end{tabular}

fuselli, are closely associated with the somewhat deeper incised surfaces covered by the previously described crassal fabric (Plate 20). The fuselli that are preserved are normally built, and consist of the body of the fusellus, made of fusellar fabric, an outer lining, and perhaps a very thin, incipient outer lamella. The fuselli are joined directly with the cortical component of the thecal wall. There is no crassal fabric layer in between (Plate 22: figure 1).

In contrast to specimen 1 , specimen 2 shows a consistent development of fuselli, with distinct fusellar boundaries in transverse sections (Plate 21). Instead of an inner lining made of multiple sheets, the inner surface of the thecae is lined with the crassal fabric. The inner thecal walls separating neighboring thecae at some points in specimen 2 show a fusellar component and a crassal fabric layer facing the cavity of one thecae. The outer thecal wall has the same construction (Figure 2). In contrast, the outer thecal wall of an adjacent theca has no traces of fusellar fabric and it seems to be composed solely of cortical fabric. Also the free part of a theca (probably an autotheca) is composed of an enigmatic fabric, much denser than fusellar and without any traces of cortical fibrils (Plate 22: figure 2). The presence of overlapping units, superficially similar to fuselli, is discernible on a section through the wall. No fusellum has been recognized, however, in the longitudinal sections through the "stem" of specimen 2. The internal surface of the wall is rough, partly lined with dense homogeneous material, partly made by uncovered cortical layers, sharply cut at the surface of the thecal cavity. The results of these somewhat confusing observations are listed in Table 2.

This unusual distribution of fusellar tissue in Mastigograptus sp. is difficult to explain. It seems unlikely to be the result of preservation. It could be the result of a secondary resorption of part of the fusellar fabric, and a subsequent substitution 
of the primary, fusellar thecal wall by a secondary one, made of the crassal fabric. The insular distribution of fuselli over the inner surface of the wall, the frequent presence of deeper "valleys" covered by secondary material, which is absent from the thecal walls on the areas coated by the primary fusellar fabric, the sharply cut layers of the cortical fabric at the surface of the thecal cavity, all lend support to such an interpretation. The biological significance of such possible resorption phenomena remains completely obscure, but its occurrence emphasizes the separate taxonomic position occupied by Mastigograptus sp. among the graptolites.

\section{The Basal Disc}

The ultrastructure of the basal disc, an organ of attachment characteristic for many sessile graptolites, has been analyzed in this paper only for Mastigograptus sp. A series of sections cut through the marginal and central parts of the basal disc, parallel to the long axis of the "stem," serve to illustrate its structure and its relationship to the "stem" of the rhabdosome (Plate 23). In transverse section the basal disc is pedestal-like. The upper surface is thicker and rather smooth, while the lower surface is thinner and differentiated into numerous filaments (Plate 23).

The disc has a layered structure, some layers being continuous with layers of the cortical component of the "stem" and in this respect it may be considered a cortical derivative (Kozlowski, 1949). At the ultrastructural level, material forming the basal disc differs in some respects from the true cortical fabric recognized in the thecal walls of Mastigograptus sp. This is especially true for the most peripheral and lowermost layers of the disc.

The upper layers of the disc are composed of a distinctly polytypic material (Plate 24) made of (1) coarser fibrils, resembling those in cortical fabric but more loosely displaced, and embedded in (2) a matrix composed of a rather dense network of randlomly oriented, finer fibrils. Adjacent layers are separated by (3) sheets, continuous with the matrix and resembling a dense, "wool felt" produced by a condensation of the fibrous material of the matrix (Plate 24: figure 1). The number of coarser, cortical fibrils decreases peripherally in each layer and diminishes toward the base of the disc. These fibrils when examined on sections cut through the center of the basal disc appear as electron dense spots. Only in a few places do they reveal their fibrous nature. The majority of the cortical fibrils within the basal disc are probably arranged concentrically (with their long axes parallel to the outer margin of the disc), and were sectioned transversally.

The lowermost layer of the basal disc and its free edge are composed of material (structurally monotypic) made of irregular, branching, and interconnecting fibrils (Plate 25). This monotypic material might be matrix only, deprived of its cortical fibrous component, which appears later in overlying layers. Some observations indicate, however, that the density of this material and the cortical fibrils is the same and is greater than the clensity of the matrix. An alternative explanation might be that in the most peripheral and lowermost layers of the basal disc, it is matrix which is lacking; the material present being similar to cortical fibers, only organized in a different way as a response to this lack of associated matrix. The lowermost layer produces numerous filaments, filled with the loose fibrous material, probably identical with that within the layer itself.

Toward the base of the "stem," the number of layers and the thickness of the basal disc increase considerably. Any given layer contains abundant cortical fibrils, which are densely packed and attain the regular cortical pattern (Plate 26: figure 1). At the same time the share of matrix is smaller. Only the lowermost layers approach the structure described previously for the marginal part of the disc, and the lower surface is differentiated into filamentous outgrowths of the same structure (Plate 25, Plate 26: figure 2). Close to the base of the "stem" of the rhabdosome, the layers of the basal disc can be subclivided into a lower fraction (layers of the basal disc proper) and an upper fraction continuous with the layers of the cortical envelope of the "stem" (Plate 23). These two systems delimit (at least in one observed case) a chamber-like cavity just below the erect portion of the rhabdosome "stem" and slightly laterally to it (Plate 23). Layers of cortex end abruptly at the wall of this cavity, the end of each being provided with a zone of homogeneous material (crassal fabric), and thus resembling the secondary thecal walls in Mastigograptus sp., as previously described. This dense structure may be related to an artifact. 
Although the nature of this cavity is obscure, it may represent an "embryonal vesicle" (a bottleshaped prosicula?), the cavity of which was secondarily enlarged due to resorption of the primary prosicular wall and the neighboring cortical tissue.

\section{Stolons and Internal Parts of Thecae}

Well preserved sclerotized sheaths of stolons and internal parts of thecae have been found in material described only in Acanthograptus sp. A transverse section through a stolotheca reveals some internal tubules which might be interpreted as a probable autothecal stolon (Plate 27) and a wider, thin-walled tubule, perhaps an internal part of a lateral theca (bitheca?-Plate 27). The opposite lateral theca is not present in this section.

The sheath of the stolon is made of crassal fabric with indistinct traces of lamellar structure, and is joined to the wall of the stolotheca by a spongy material, traceable as an extension in the wall of the stolon (Plates 27, 28). The presumed internal part of a lateral theca, enclosed inside its mother stolotheca, is rather thin-walled, shows more laminar structure, and is joined with the wall of the stolotheca by some spongy material (Plate 27).

Other sections, cut slightly obliquely, reveal unusually thick-walled stolonal sheaths, most probably sectioned close to the point of their trifurcation, slightly above the stolonal node (Plate 29). Their walls are composed of an external layer of spongy aspect, and an internal compact material, forming at certain places distinct protuberances (swellings) directed inside the stolonal cavity, similar to that described by Kozlowski (1949: 2526, figure 3 ) in Dendrograptus regularis. In one case these protuberances distinctly outline a coming trifurcation of the stolon close to the node. In another case the extremely thick-walled stolon is provided with a restricted channel and it shows a distinct spongy structure of the wall, which is, however, different from fusellar tissue (Plate 30). Although the stolons in Acanthograptus sp. display a variety of fabrics in their sclerotized walls, the most frequent seems to be the compact, homogeneous material, defined previously as the crassal fabric.

\section{Literature Cited}

Andres, $\mathbf{D}$.

1961. Die Struktur von Mastigograpten aus einem Ordovizischen Geschiebe Berlins. Neues Jahrbuch für Geologie und Paläontologie, Monatshefte, 12:636647.

Berry, W. B. N., and R. S. Takagi

1970. Electron Microscope Investigations of Orthograptus quadrimucronatus from the Maquoketa Formation (Late Ordovician) in Iowa. Journal of Paleontology, 44 (1):117-124.

1971. Electron Microscope Study of a Diplograptus Species. Lethaia, 4:1-13.

Bulman, O. M. B., and R. B. Rickards

1966. A Revision of Wiman's Dendroid and Tuboid Graptolites. University of Uppsala, Bulletin of the Geological Institution, 43:1-72.

Bulman, O. M. B.

1970. Graptolithina with Sections on Enteropneusta and Pterobranchia. In R. C. Moore, Treatise on Invertebrate Paleontology, Part V, 2nd ed. Boulder, Colorado: Geological Society of America.

Foucart, M. F., S. Bricteaux-Grégoire, Ch. Jeuniaux, and M. Florkin

1965. Fossil Proteins of Graptolites. Life Sciences, 4:467471.

Foucart, M. F., and Ch. Jeuniaux

1966. Paléobiochimie et position systématique des Grapto- lites. Annales Société Royal Zoologique de Belgique, 95(2):39-45.

Gross, J., and K. A. Piez

1960. The Nature of Collagen, I: Invertebrate Collagens. Pages 395-409 in R. F. Sognnaes, Calcification in Biological Systems. Washington, D.C.: American Association for the Advancement of Science.

Hare, P. E.

1965. Amino Acid Artifacts in Organic Geochemistry. Pages 232-235 in Carnegie Institution, Annual Re port of the Director, Geophysical Laboratory.

1969. Geochemistry of Proteins, Peptides, and Amino Acids. In G. Eglinton and M. Murphy, Organic Geochemistry. Berlin: Springer-Verlag.

Jaanusson, $\mathrm{V}$.

1960. Graptoloids from the Ontikan and Viruan (Ordovician) Limestones of Estonia and Sweden. University of Uppsala, Bulletin of the Geological Institution, 38:289-366.

Jakus, M. A.

1964. Ocular Fine Structure. Boston: Little, Brown Co. Kozlowski, R.

1938. Information préliminaires sur les Graptolithes du Tremadoc de la Pologne et sur leur portée théorique. Annales Musei Zoologici Polonici, 13:183-196.

1949. Les Graptolithes et quelques nouveaux groupes d'animaux du Tremadoc de la Pologne. Palaeon. tologia Polonica, 3:1-235. 
1959. Les Hydroides ordoviciens à squelette chitineux. Acta Palaeontologica Polonica, 4:209-271.

1962. Crustoidea, nouveau groupe de Graptolites. Acta Palaeontologica Polonica, 7:3-52.

1965. Oeufs fossiles des Céphalopodes? Acta Palaeontologica Polonica, 10:1, 3-9.

1966. On the Structure and Relationship of Graptolites. Journal of Paleontology, 40:489-501.

Kraatz, R.

1964. Untersuchungen über die Wandstrukturen des Graptolithen (mit Hilfe des Elektronenmikroskops). Zeitschrift der Deutschen geologischen Gesellschaft, 114:699-702.

1968. Elektronenmikroskopische Beobachtungen an Monograptus-Rhabdosomen. Der Aufschluss, 12:357-361.

Kraft, P.

1926. Ontogenetische Entwicklung und Biologie von Diplograptus und Monograptus. Paläontologische Zeitschrift, 7:207-249.

Kühne, W. G.

1955. Unterludlow-Graptolithen aus Berliner Geschieben. Neues Jahrbuch für Geologie und Paläontologie, Abhandlungen, 100(3):350-401.

Manskaya, S. M., and T. V. Drozdova

1962. Transformation of Organic Compounds in Sedimentary Rocks and the Organic Matter of Graptolites of Dictyonema Shales. Geokhimiya, 11:953962.

Mathews, M. B.

1965. The Interaction of Collagen and Acid Mucopolysaccharides. A Model for Connective Tissue. Bio. chemical Journal, 96:710-716.

Pease, D. C.

1964. Histological Techniques for Electron Microscopy. New York: Academic Press.
Porter, K. R.

1964. Morphogenesis of Connective Tissue. Pages 6-36 in C. A. L. Stephens and A. B. Stanfield, Cellular Concepts in Rheumatoid Arthritis. Springfield: Charles C. Thomas.

Rickards, R. B., P. J. Hyde, and D. H. Krinsley

1971. Periderm Ultrastructure of a Species of Monograptus (Phylum Hemichordata). Proceedings of the Royal Society, London, Series B, 178:347-356.

Rudall, K. M.

1955. The Distribution of Collagen and Chitin. Symposia of the Society for Experimental Biology, 9:49-70.

Shackleford, J. M.

1971. The Indifferent Fiber Plexus and Its Relationship to Principal Fibers of the Periodontium. American Journal of Anatomy, 131(4):427-441.

Towe, K. M., and A. Urbanek

1972. Collagen-like Structures in Ordovician Graptolite Periderm. Nature, 237(5356):443-445.

Urbanek, $A$.

1959. On the Development and Structure of the Graptolite Genus Gymnograptus. Acta Palaeontologica Polonica, 4:279-336.

Waddington, C. H.

1962. New Patterns in Genetics and Development. New York: Columbia University Press.

Wetzel, W

1958. Graptolithen und ihre fraglichen Verwandten im elektronenmikroskopischen Vergleich. Neues Jahrbuch für Geologie und Paläontologie, Monatshefte, 7:307-312. 


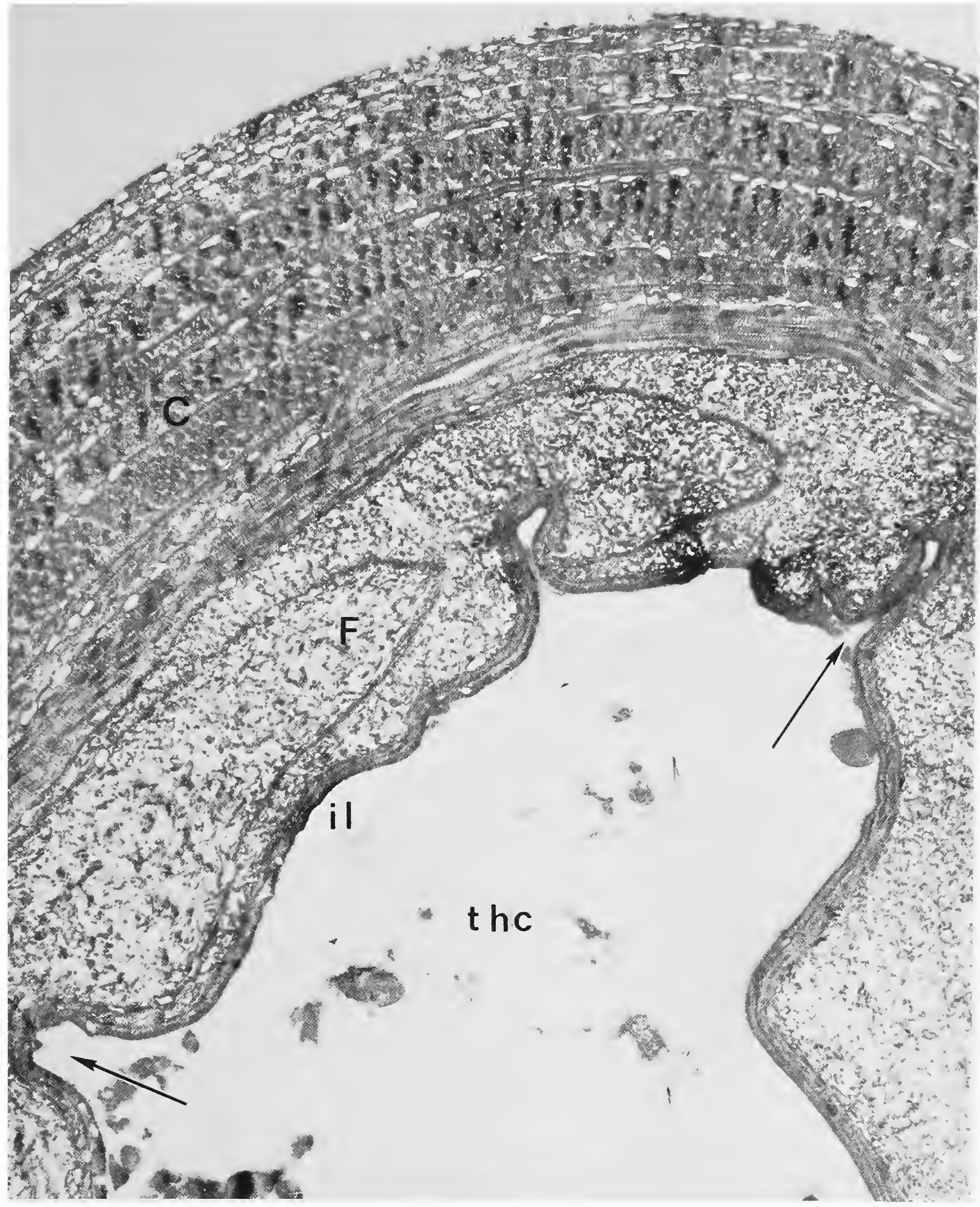

Plate 1.-Dictyonema sp. Structural features of the major constituents of the periderm as seen on transverse sections. Shown is the thecal cavity (thc), outer cortex (C), fusellum (F), the inner lining (il), and infoldings of the inner surface of the fuselli (arrows) ( $\times 12000)$. 


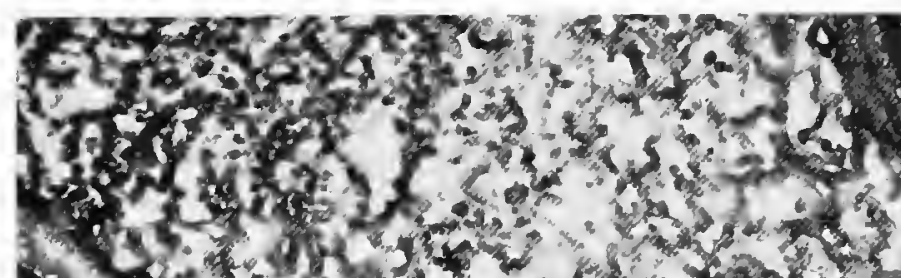

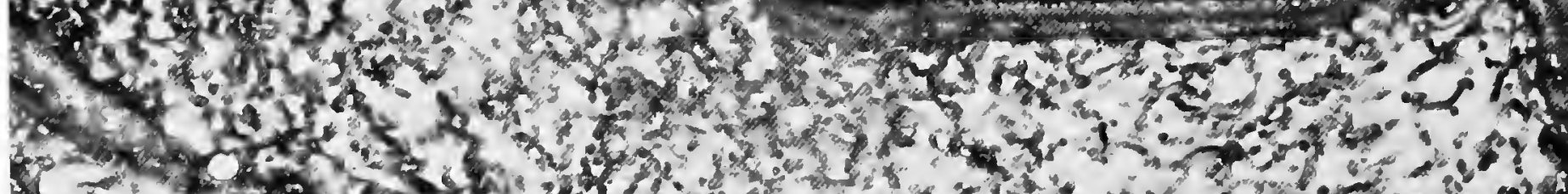

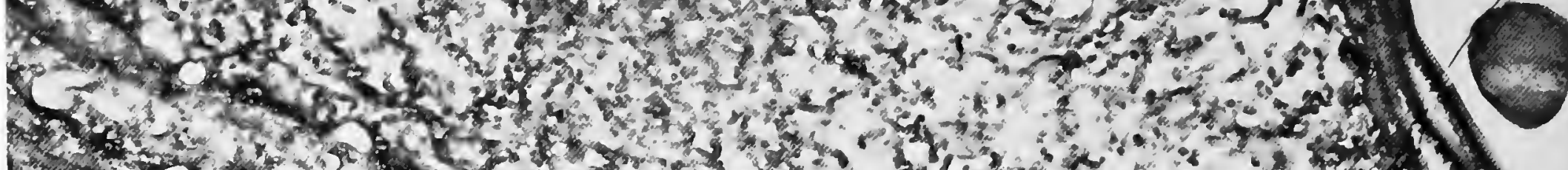

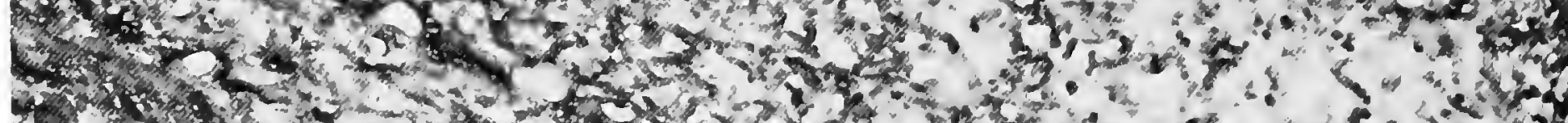
1.

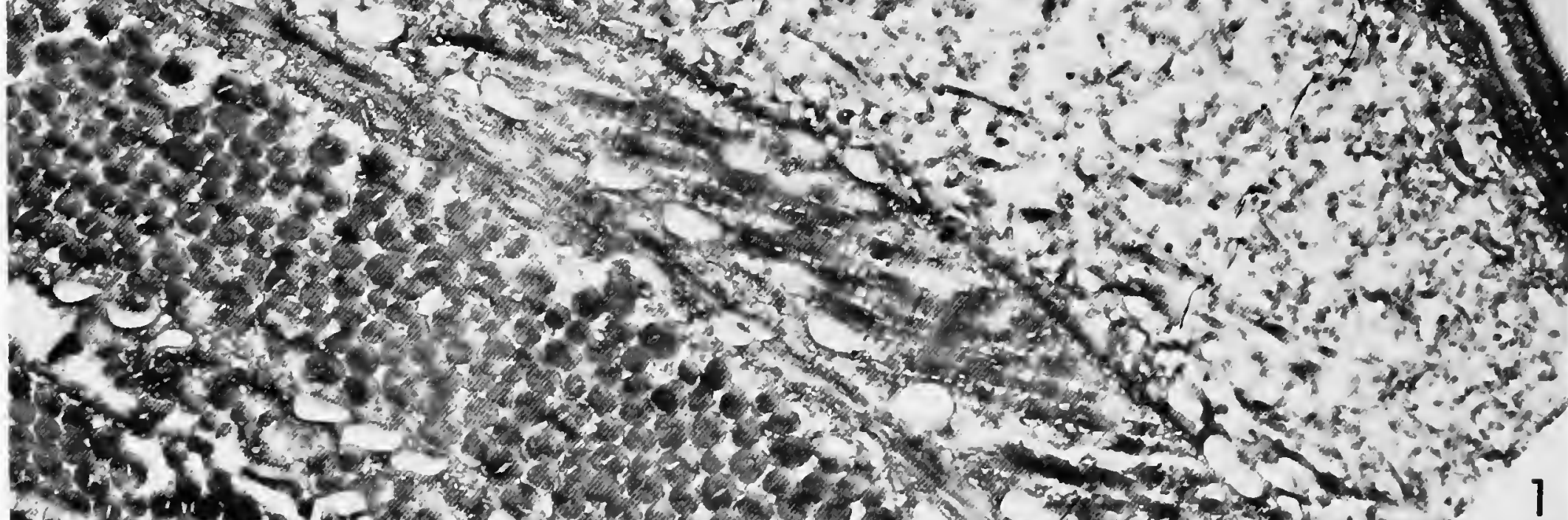

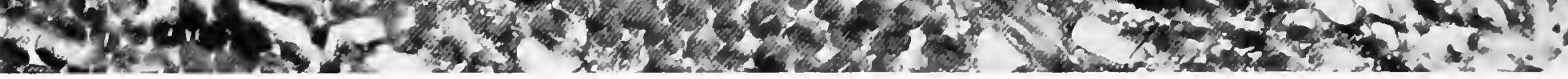

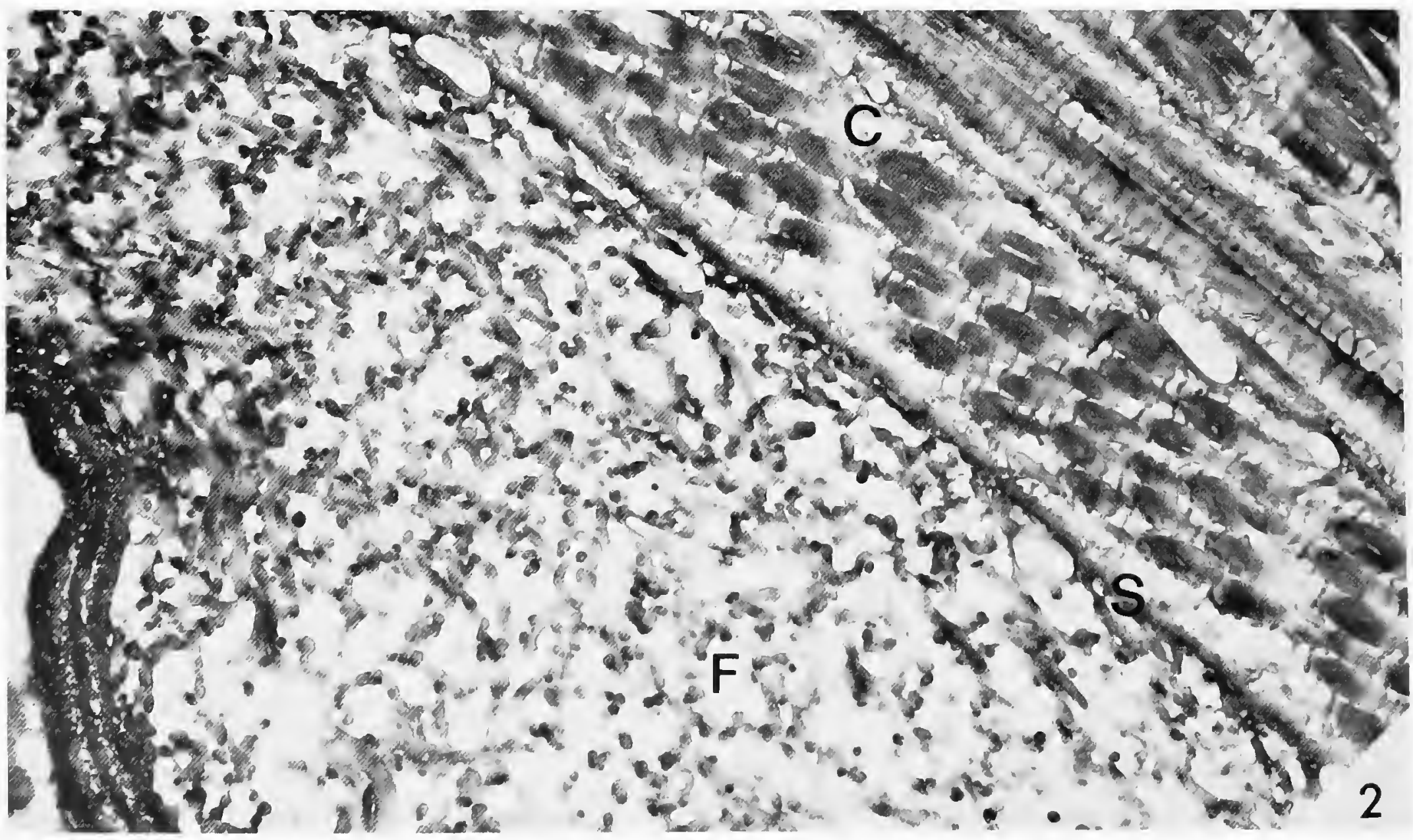

Plate 2.-Dictyonema sp. Structural details of la-fusellar (F) and 1 b-cortical (C) fabrics in transverse section. Also shown are sheet fabric (S) and multiple sheet construction of the inner lining (il) (figure 1, $\times 18000$; figure 2, $\times 28000$ ). 

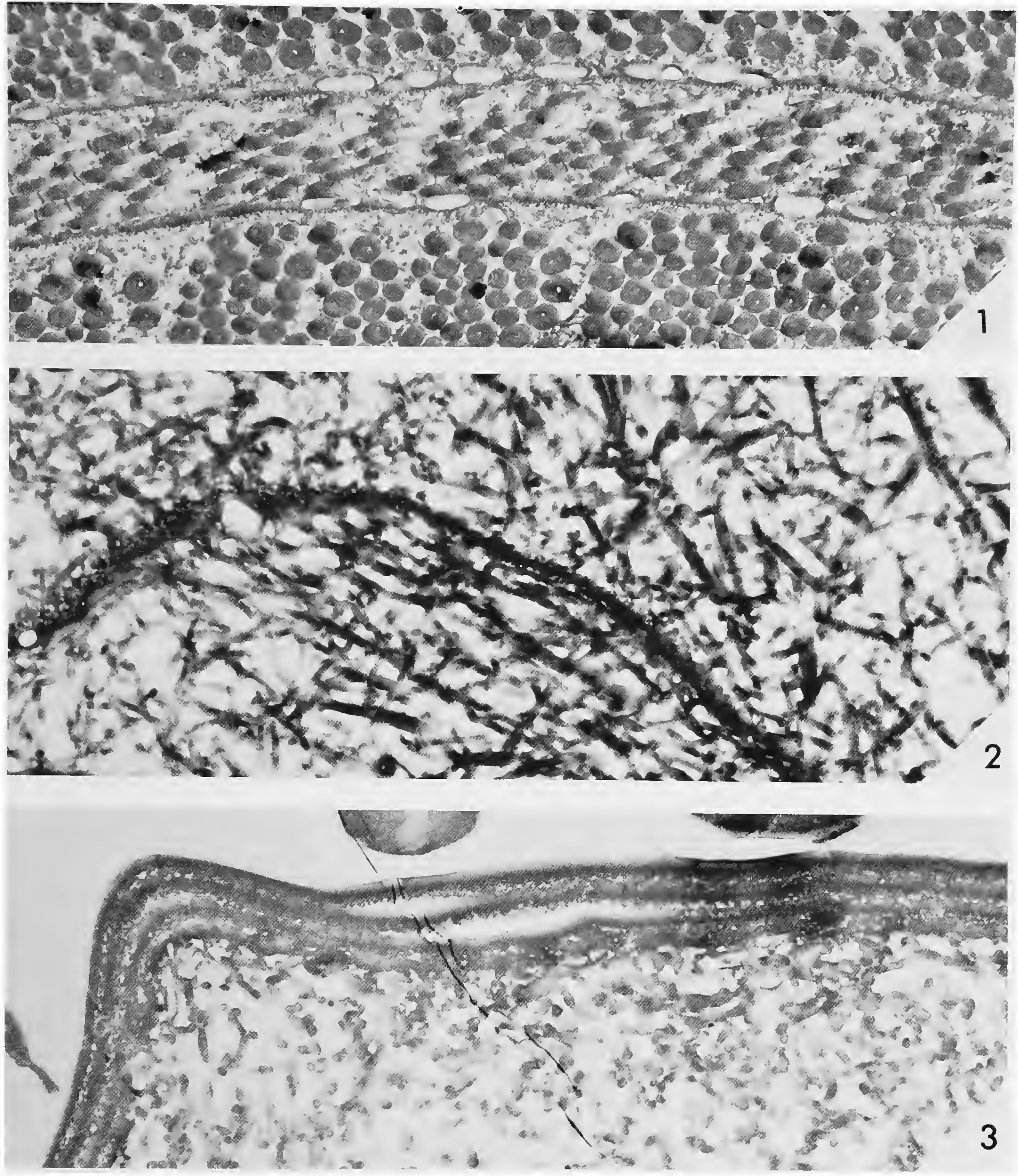

Plate 3.-Structural varieties of $1 c$-sheet fabric. Figure 1 shows vesicular $1 c_{1}$-sheet fabric in the cortex of Dictyonema sp. $(\times 20000)$. Figure 2 shows the $1 c_{2}$-sheet fabric delimiting fuselli in Dictyonema sp. $(\times 22000)$. Figure 3 is the multiple $1 c_{3}-$ type from the inner lining of Dictyonema sp. (X 32000). 

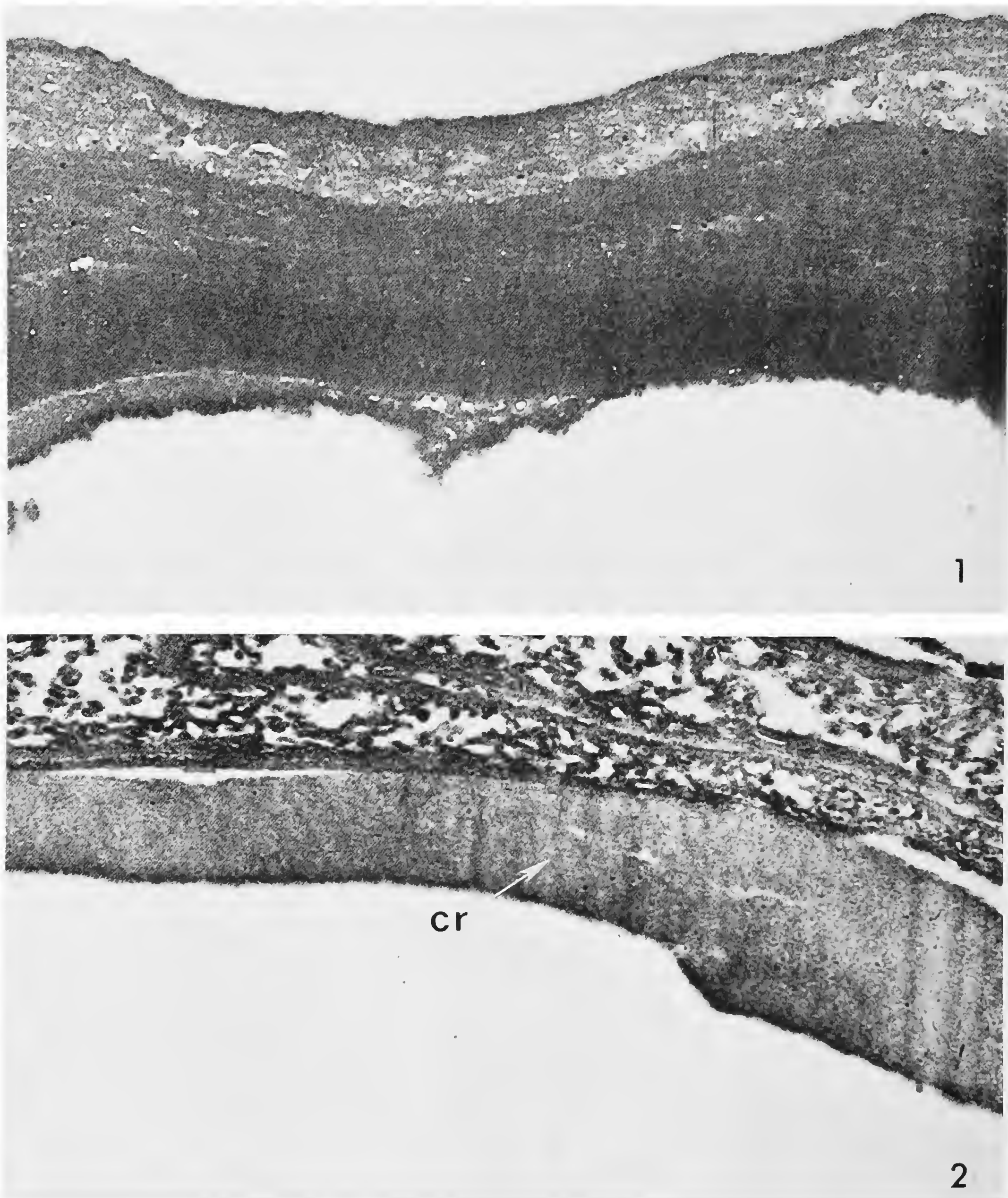

Plate 4-Examples of the dense ld-crassal fabric as recognized in the stolons of Acanthograptus sp. (figure $1, \times 30000$ ) and in the thecal walls of Mastigograptus sp. (figure $2, \times 25000$ ). 

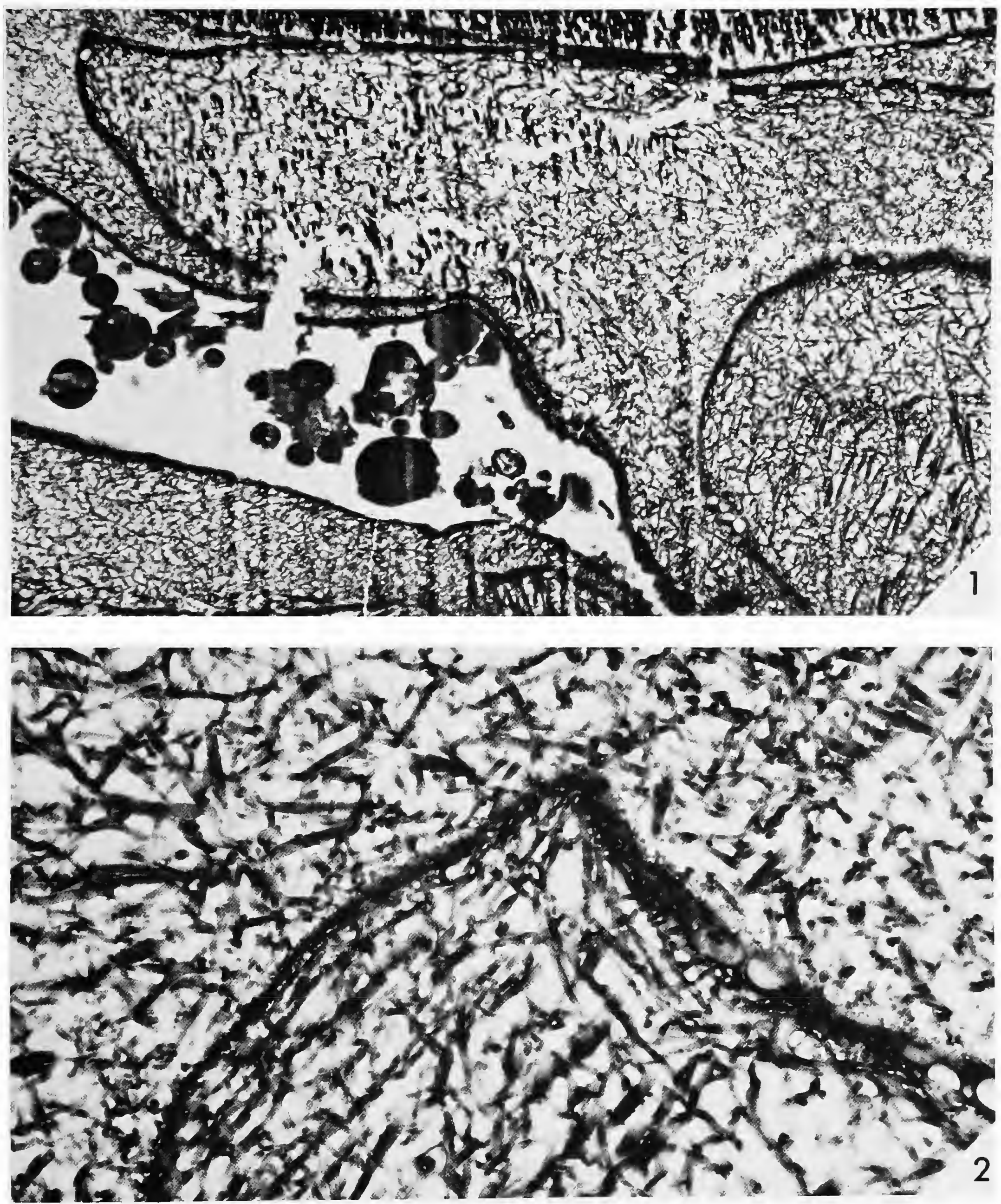

Plate 5.-Dictyonema sp. Structural features of the fusellar fabric examined in longitudinal sections of the fusellum (figure 1, $\times 7000$; figure $2, \times 22000$ ). 

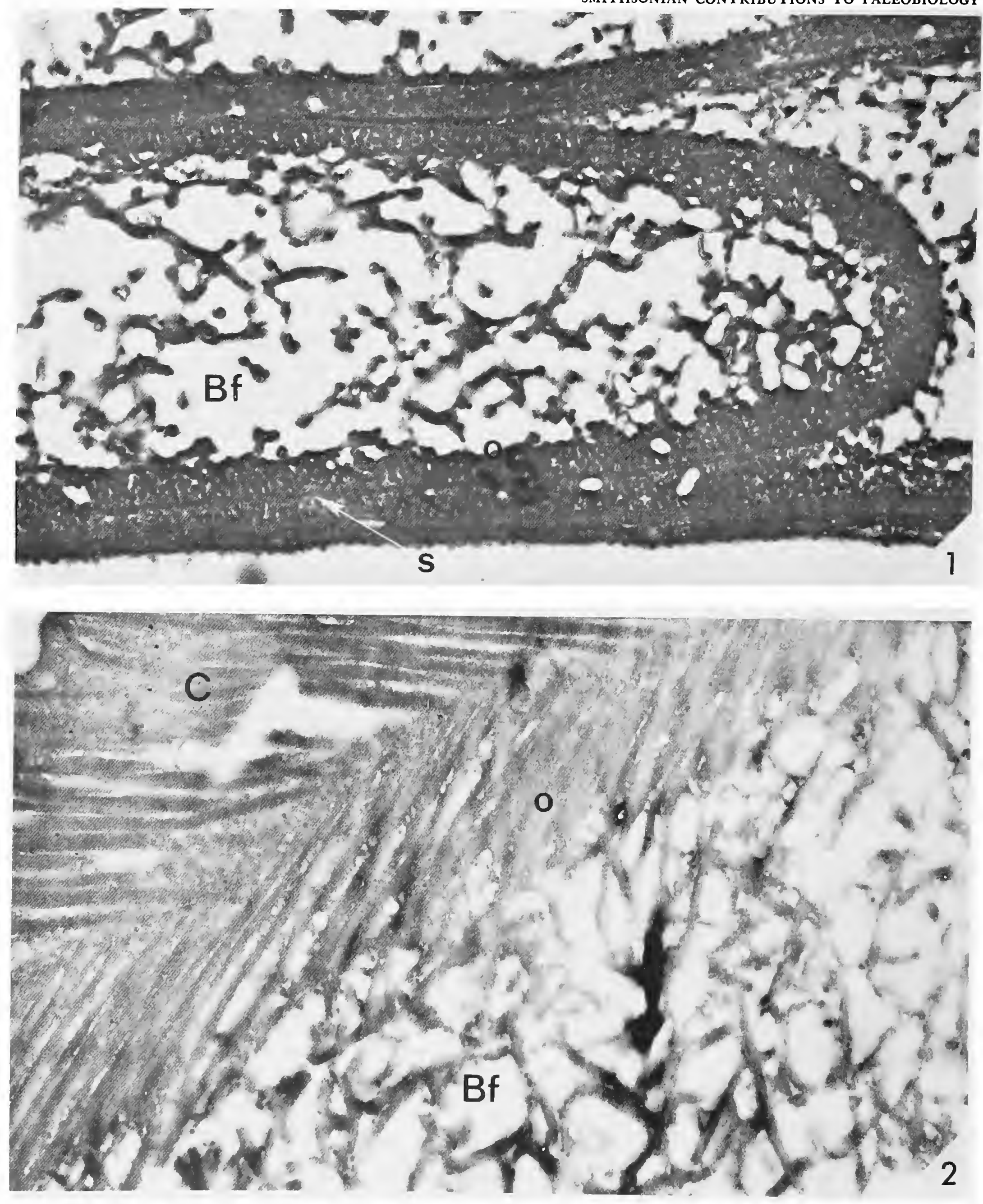

Plate 6.-Acanthograptus sp. Structural features of the fusellar fabric in the fusellum as seen in longitudinal section (figure $1, \times 24000$ ). Figure 2 is a shallow, tangential section near the top of a fusellus with its adjacent cortex $(X 28000)$. Bf, body of the fusellus; C, cortex; o, outer lamella of the fusellus; $S$, sheet fabric of the outer pellicle. 


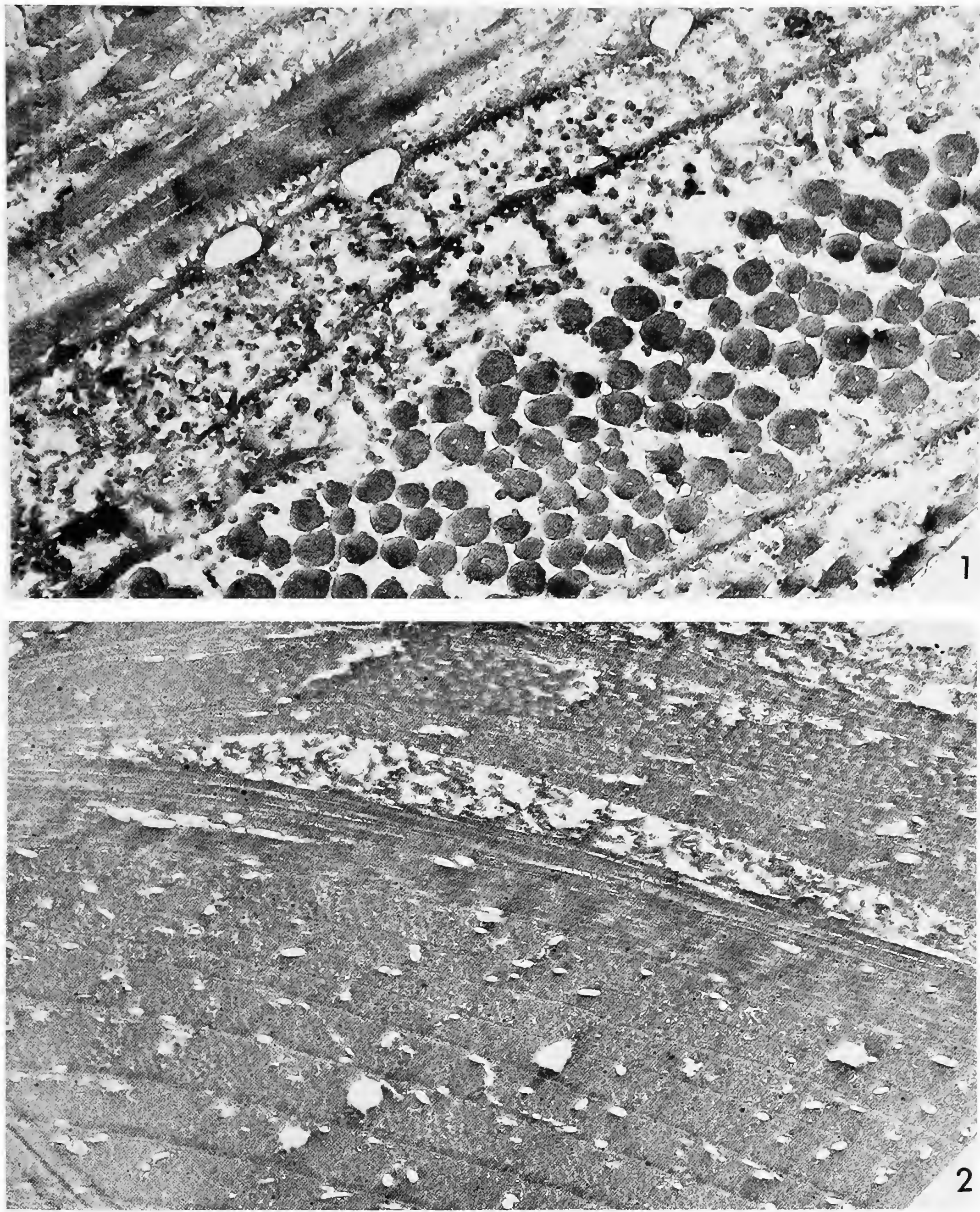

Plate 7.-Pseudofusellar and fusellar intercalations within the cortex of Dictyonema (figure 1, $\times 35000$ ) and Acanthograptus (figure $2, \times 15000$ ). 


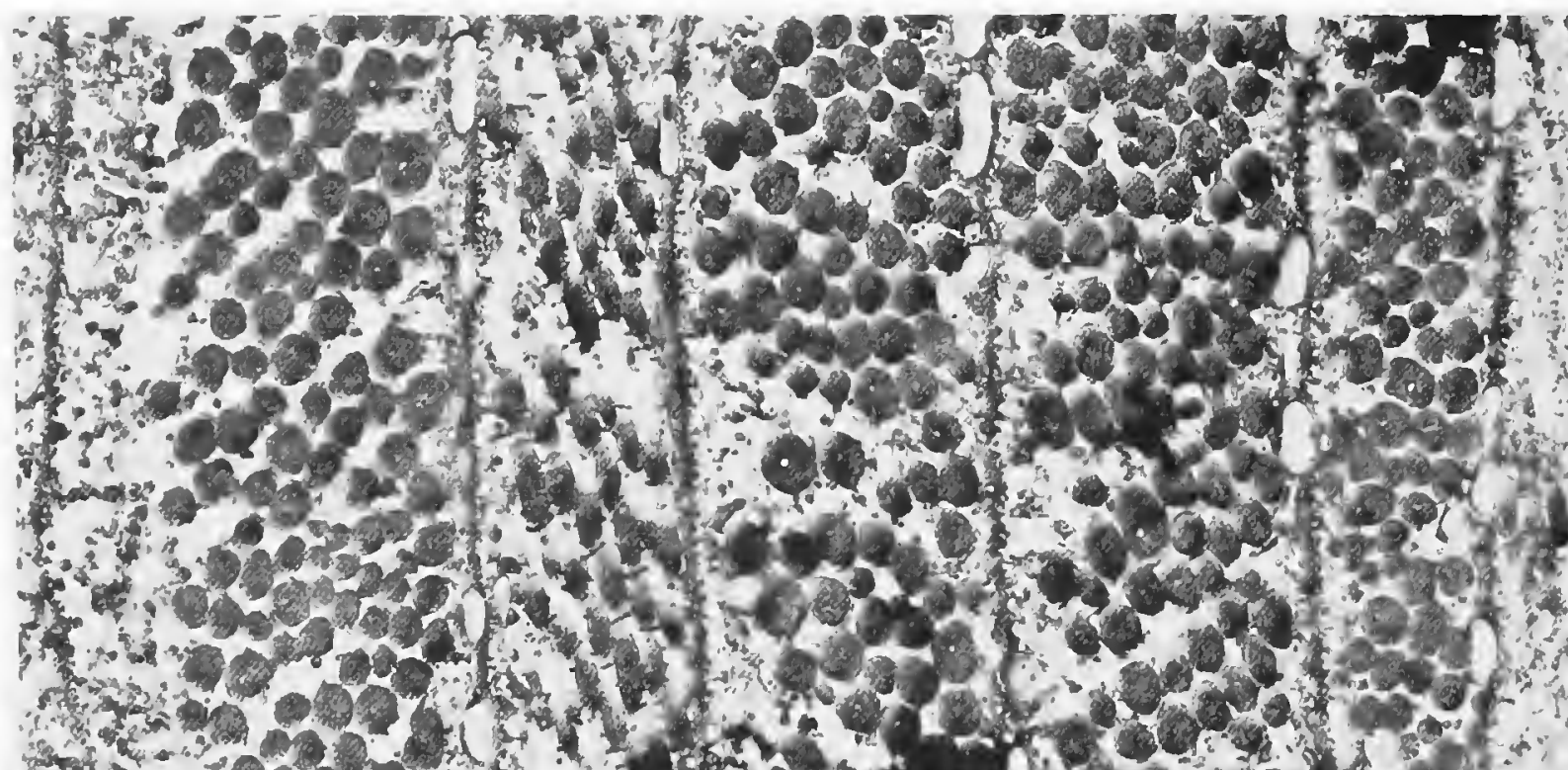
H.
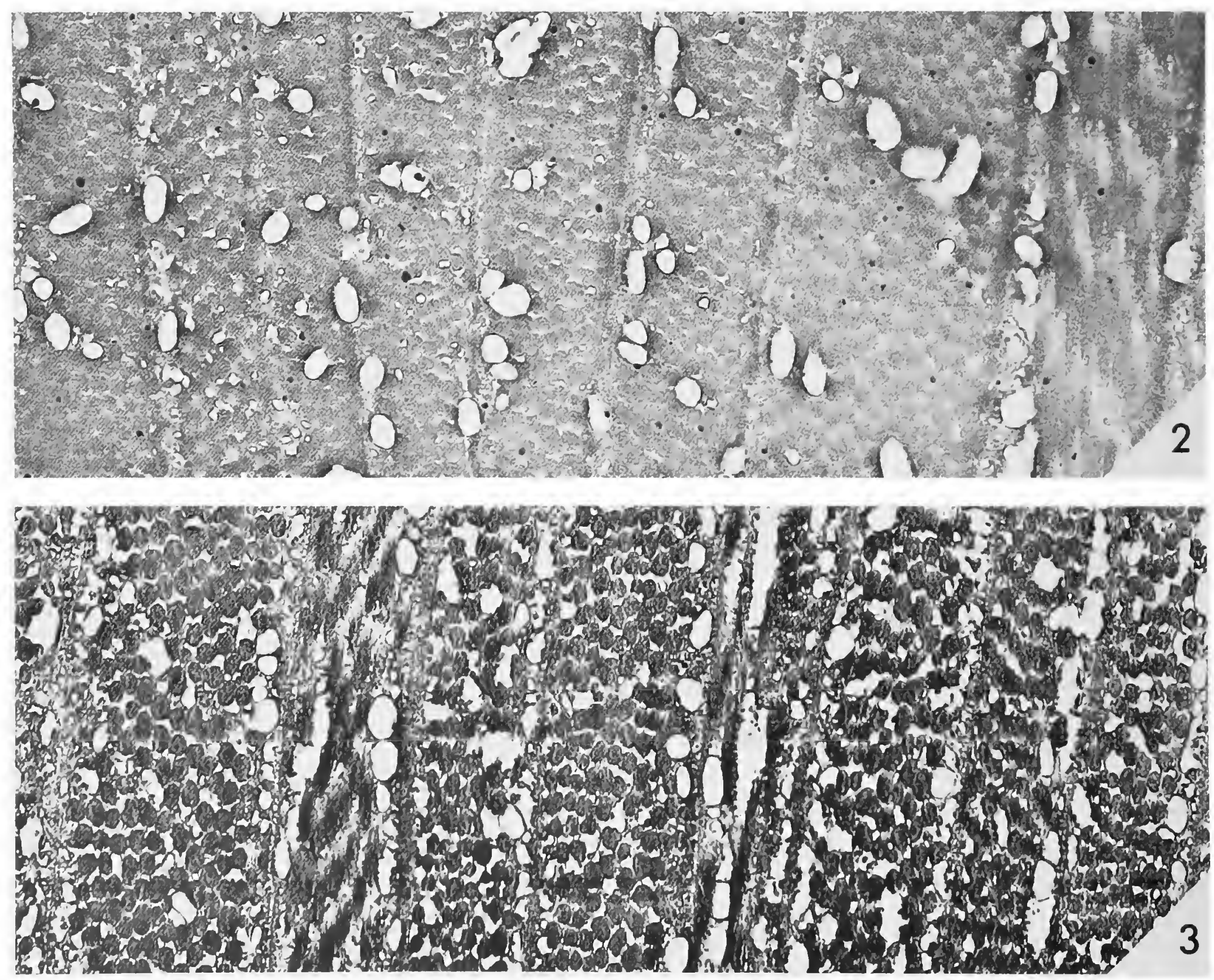

Plate 8.-Structural examples of the cortical fabric in Dictyonema (figure 1, $\times$ 17000); in Acanthograptus (figure 2, $\times$ 30000); and in Mastigograptus (figure 3, $\times 20000$ ). 

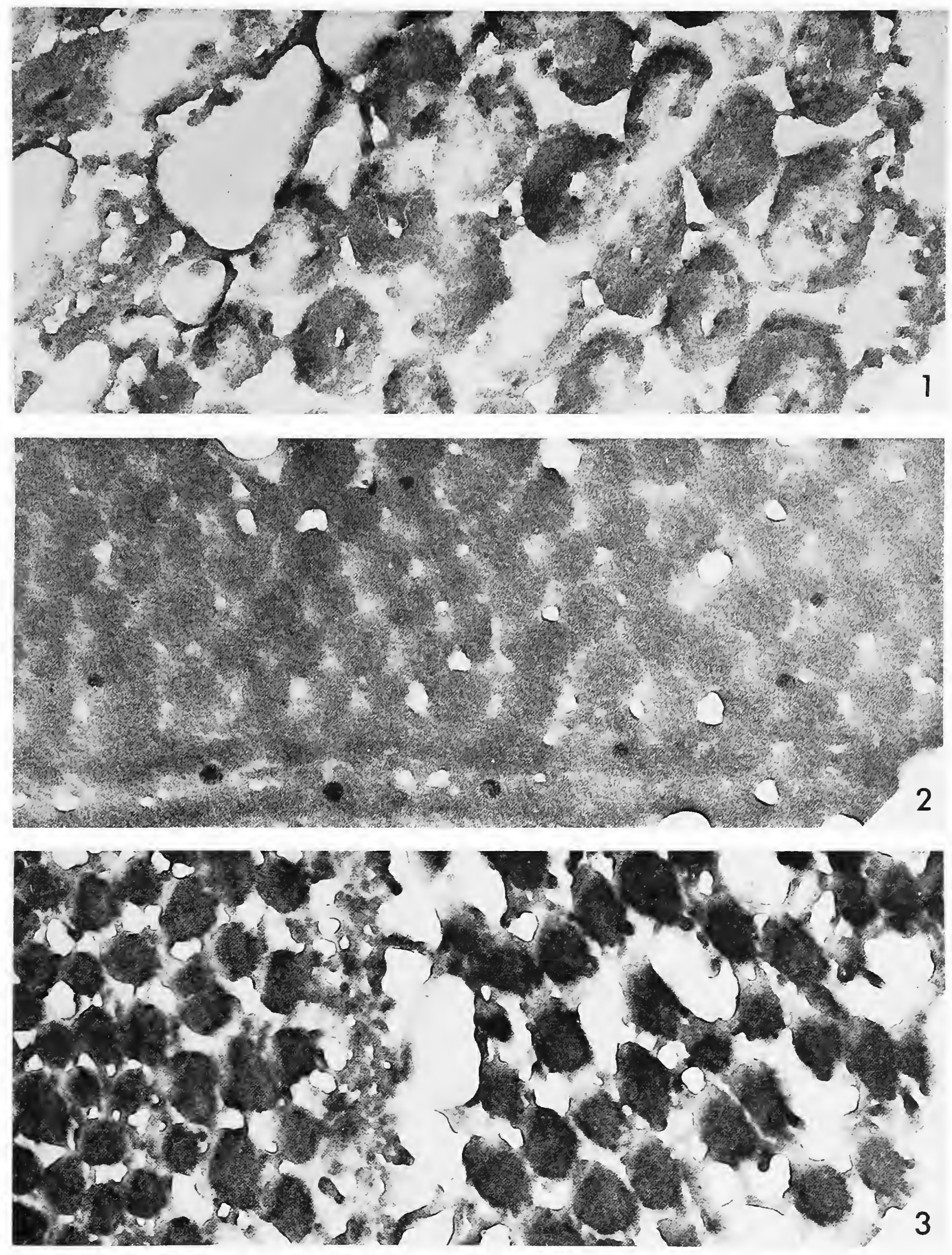

PLATE 9.-Organization of the matrix associated with the cortical fabric as seen in transverse sections of Dictyonema (figure 1, $\times 90000$ ); Acanthograptus (figure 2, $\times 120000$ ); and in Mastigograptus (figure $3, \times 75000$ ). 


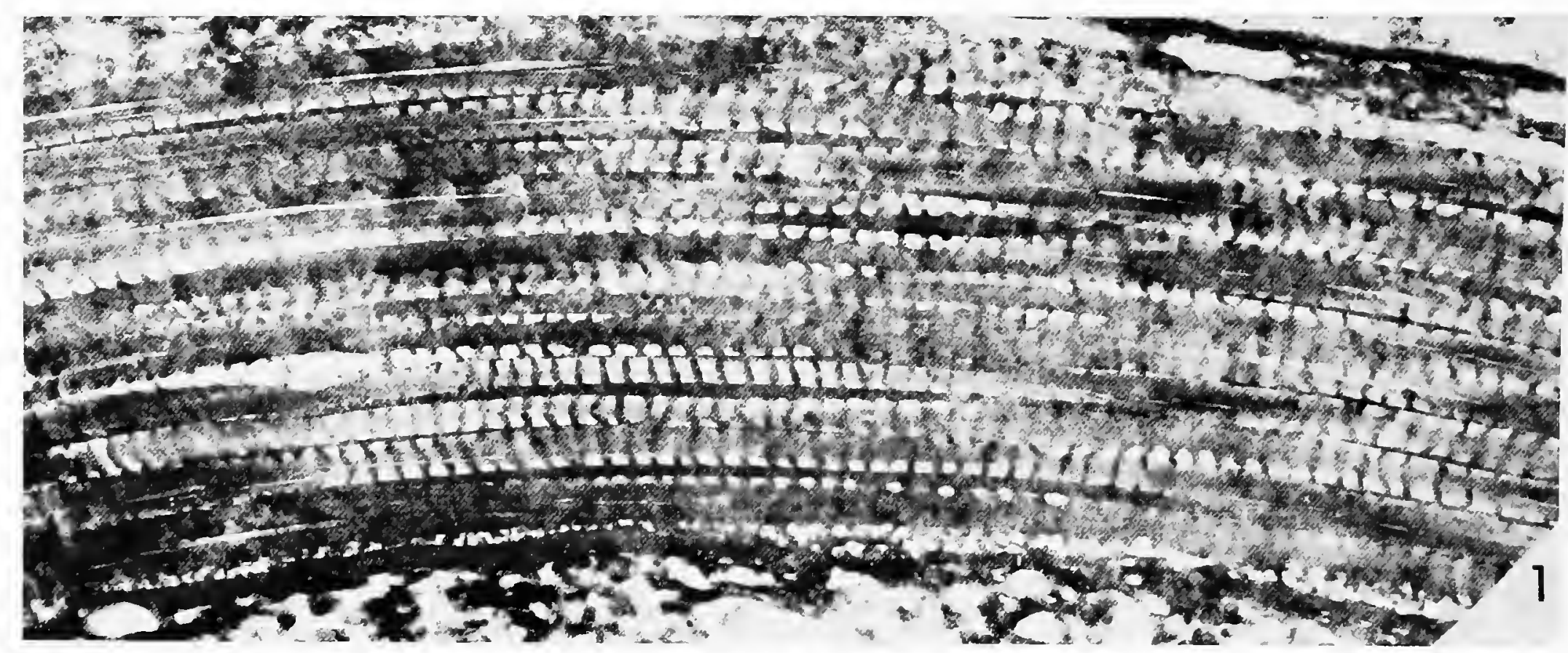

(2)

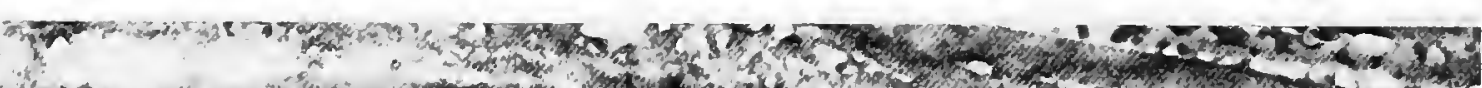

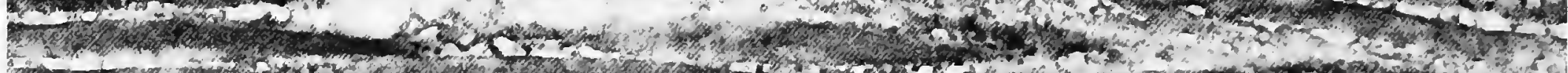
1. 17.

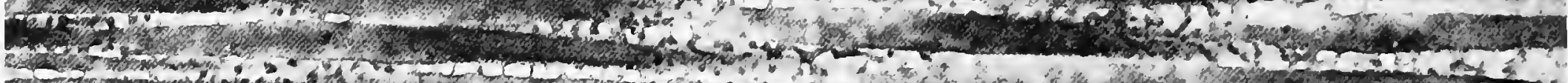

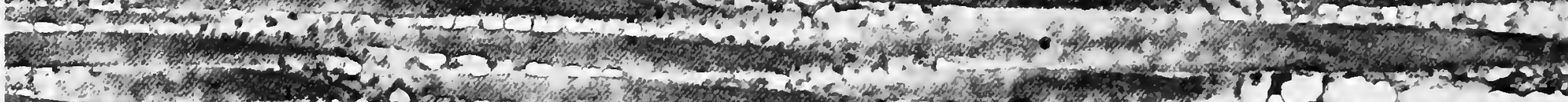
5.

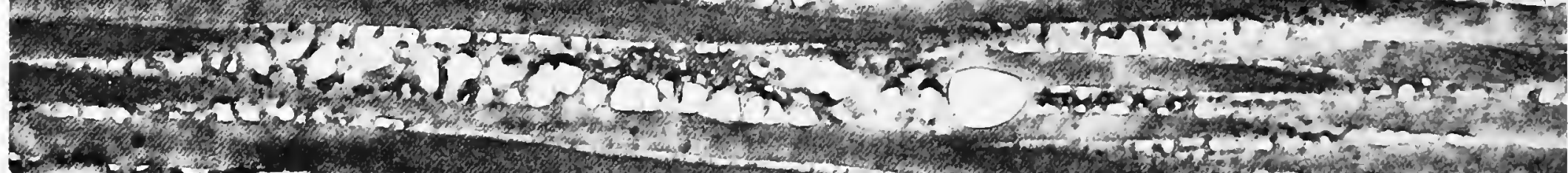
1

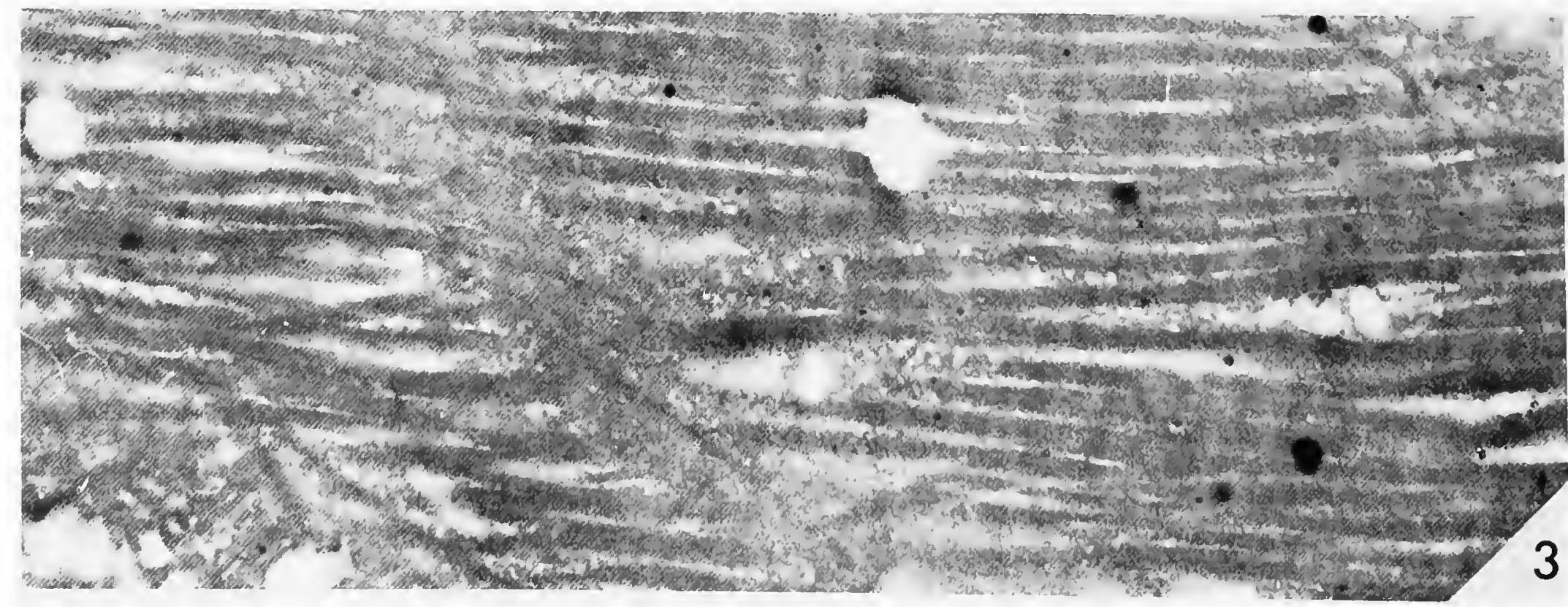

PLATE 10.-Organization of the matrix associated with the cortical fabric as seen in longitudinal sections of Dictyonema (figure 1, $\times 40000$ ); Acanthograptus (figure 2, $\times 32000$ ); and in Mastigograptus (figure $3, \times 30000$ ). 
1.3.

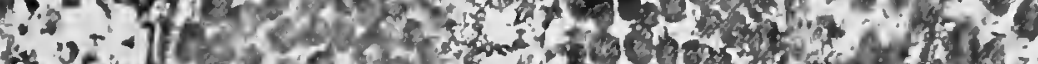

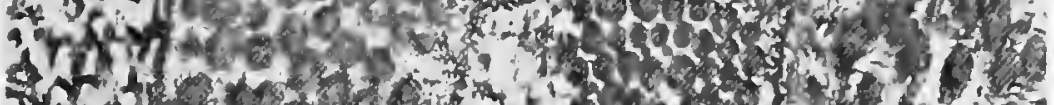

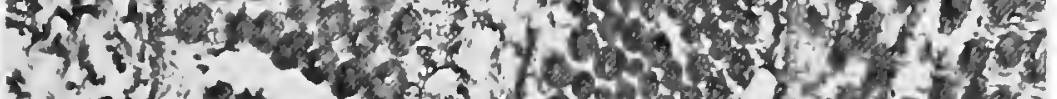

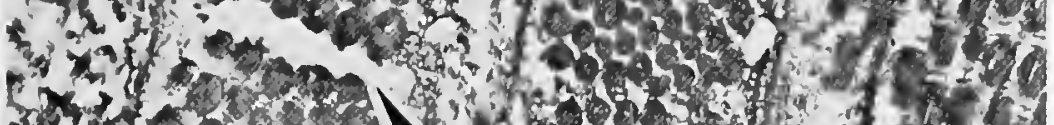

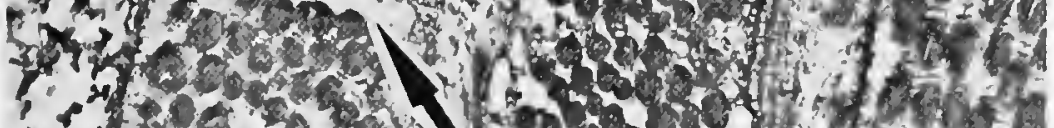

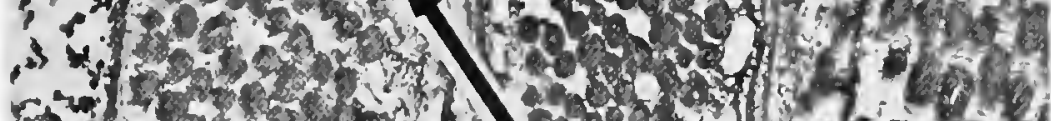

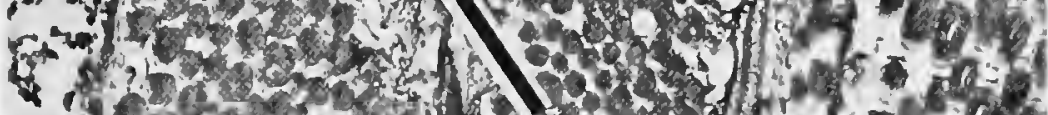
43.

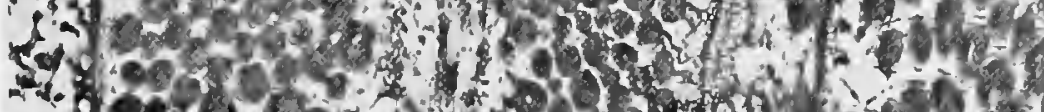

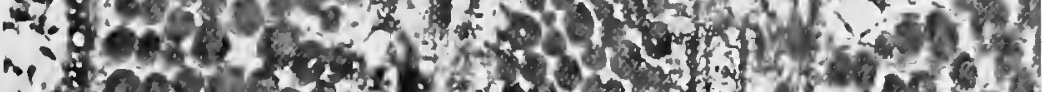

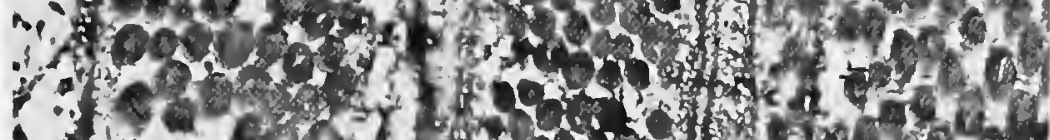

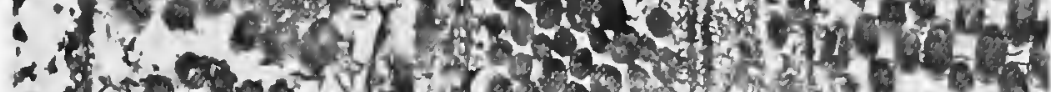

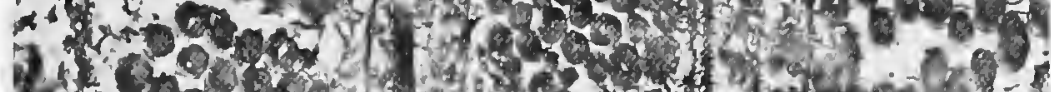

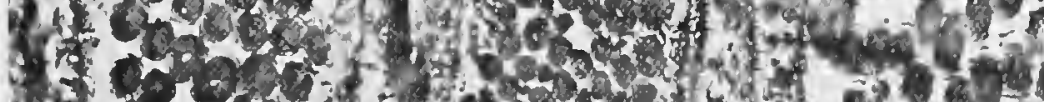

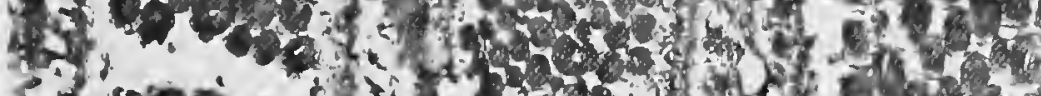

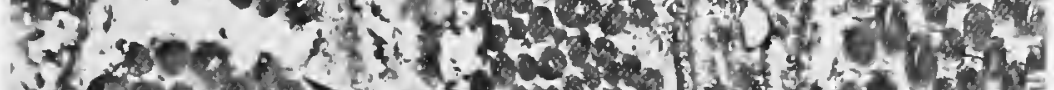

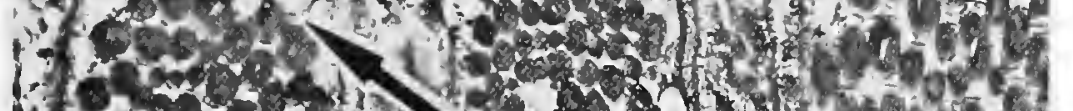

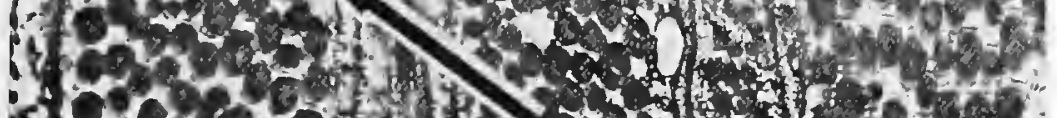

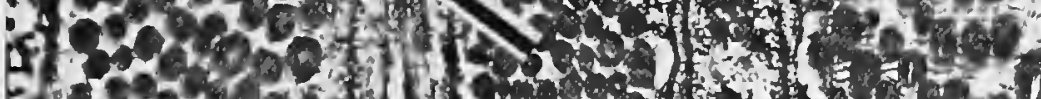

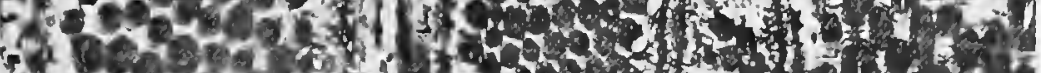

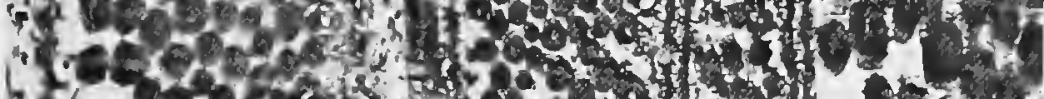

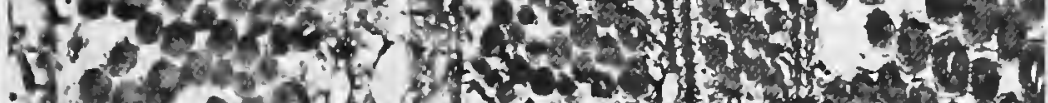

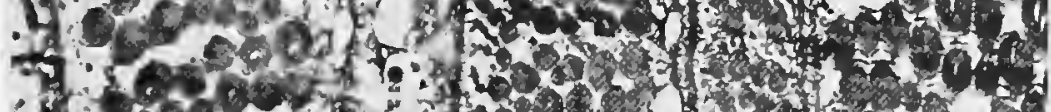

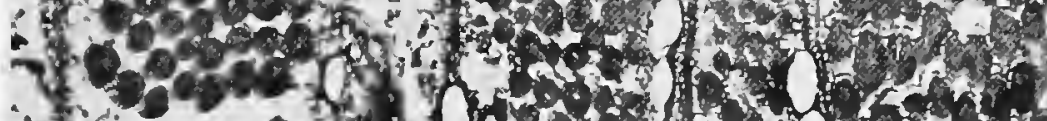

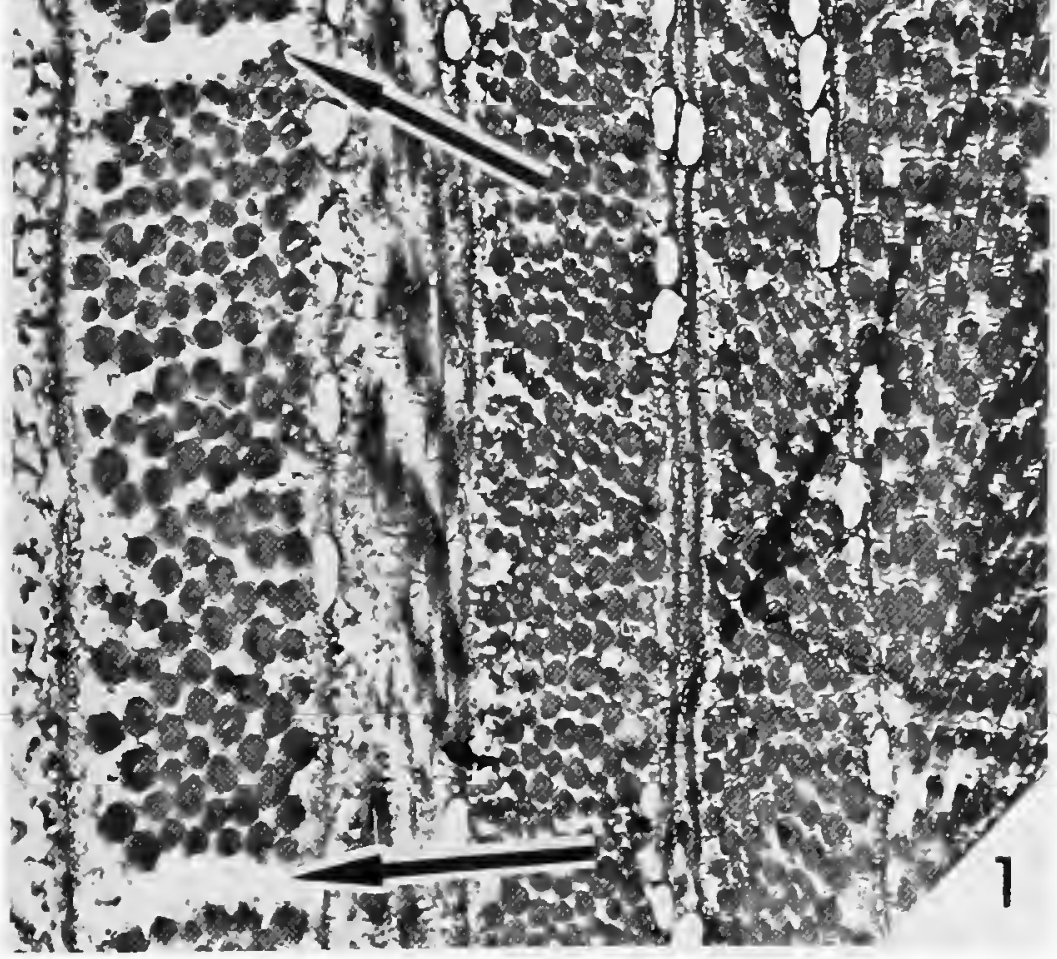

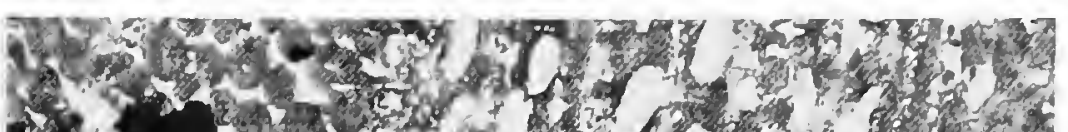
20.5.

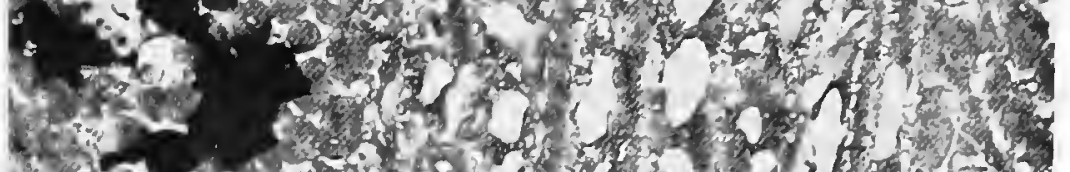

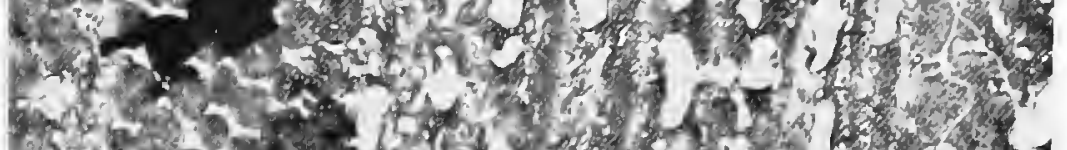

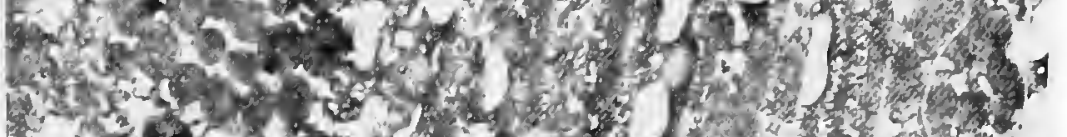

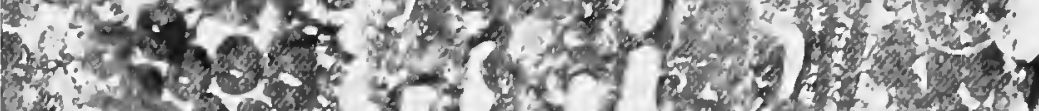

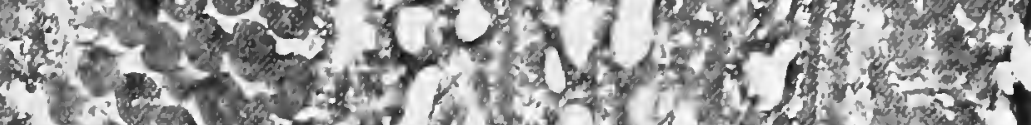

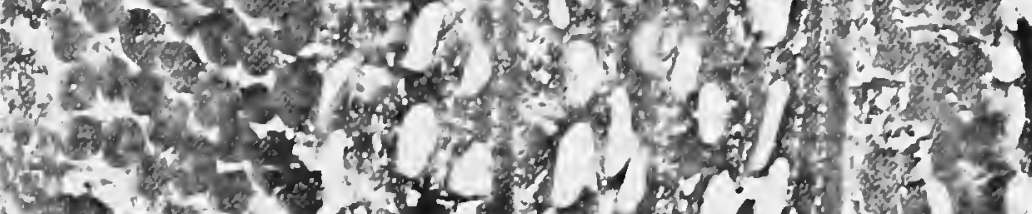

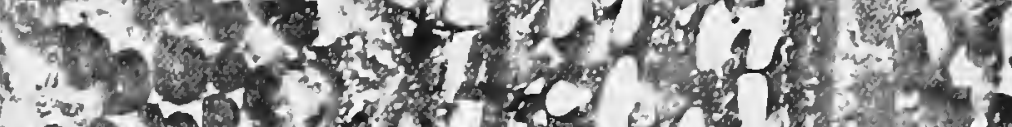
- 2.

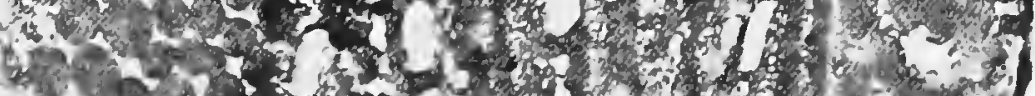

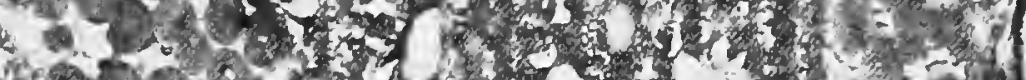

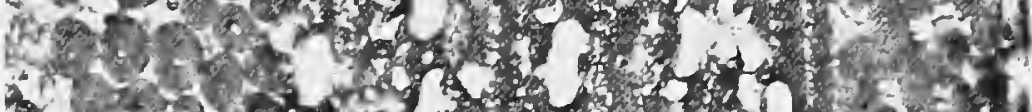

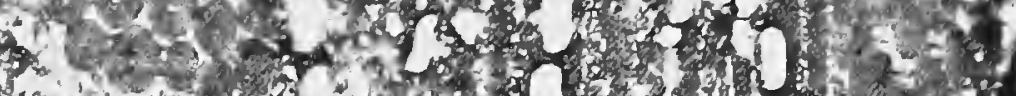

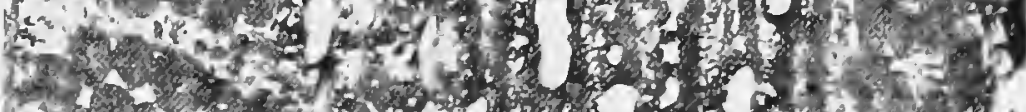

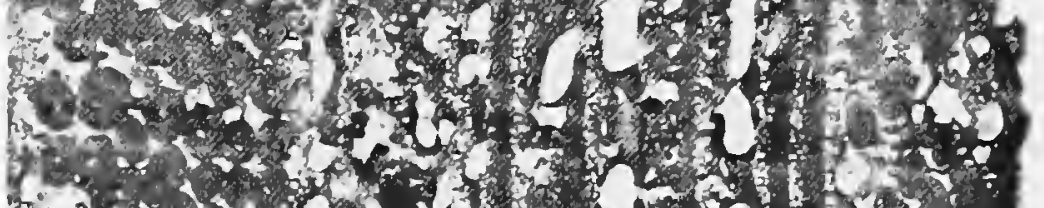
3.

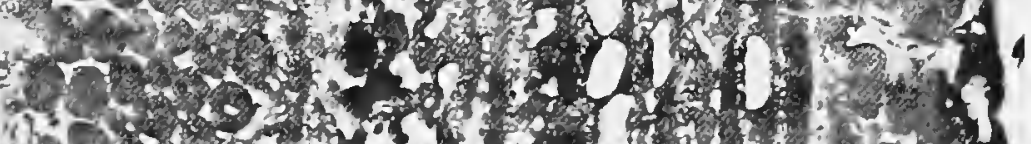

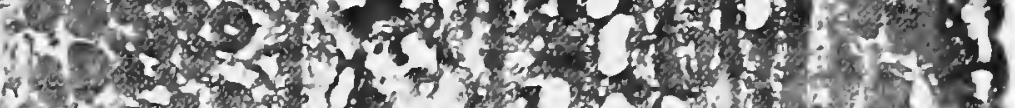
M.

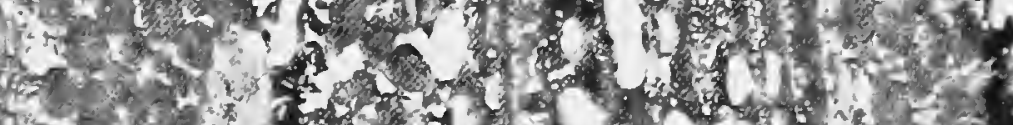

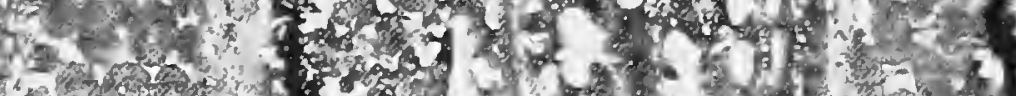

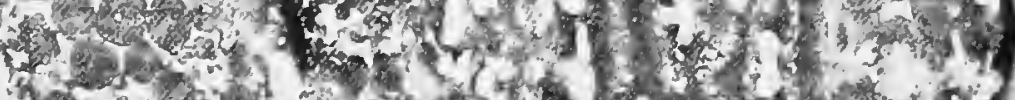

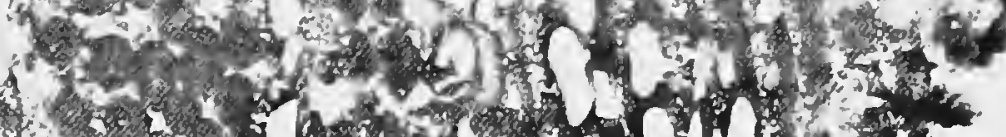
(2) 2. (1)

Plate 11.-Dictyonema sp. Double and multiple sheets produced by the tapering of cortical layers. Figure 1 shows the arrows pointing to the junctions between bundles of fibrils within a single layer of the cortex (figure 1, X 14000; figure 2, $\times 20000$ ). 

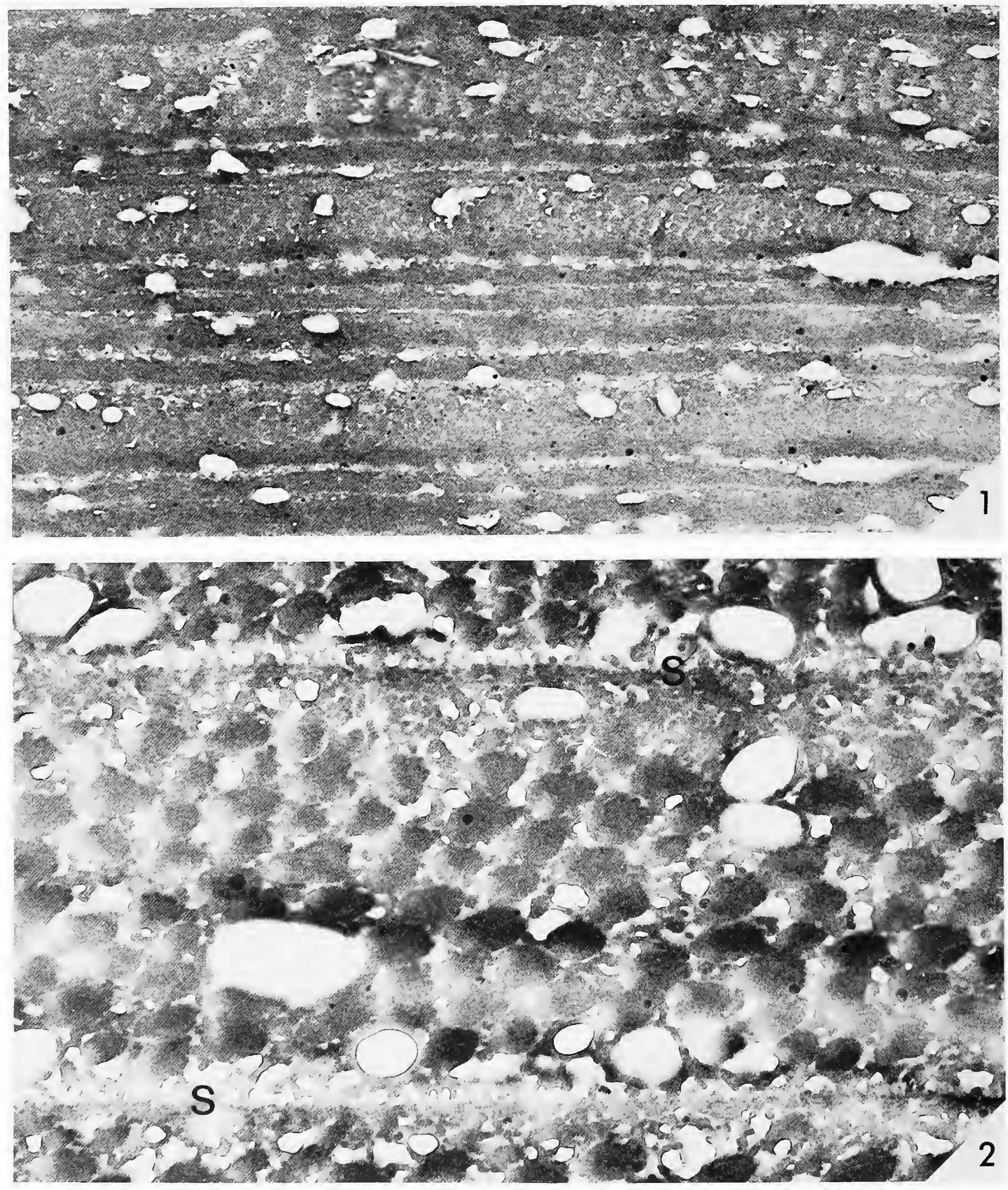

Plate 12,-Figure 1, Acanthograptus sp. Repeated deposition of sheet fabric within the outer zone of the cortex $(\times 33000)$. Figure 2, Mastigograptus sp. Sheet fabric with admembrane vesicles between the layers of the cortex $(\times 55000)$. 

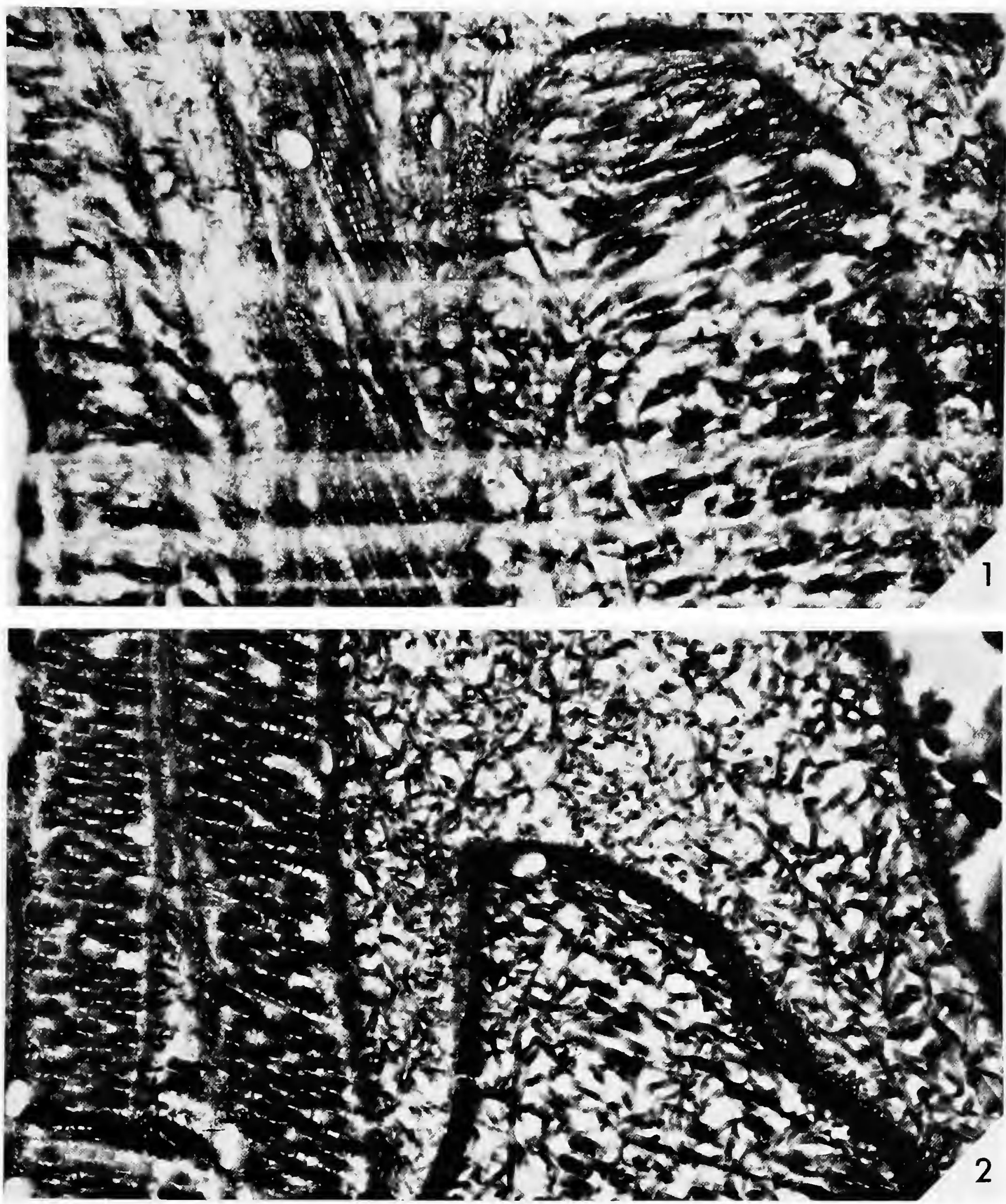

Plate 13.-Dictyonema sp. Transition between fusellar and cortical fabric within a single fusellus (figure 1, $\times 18000$ ). Figure 2 shows there is a contrast between the coarser "cortical" fibrils at the top of one fusellus and the more delicate genuine fusellar fabric at the base of the next one $(X 18000)$. 


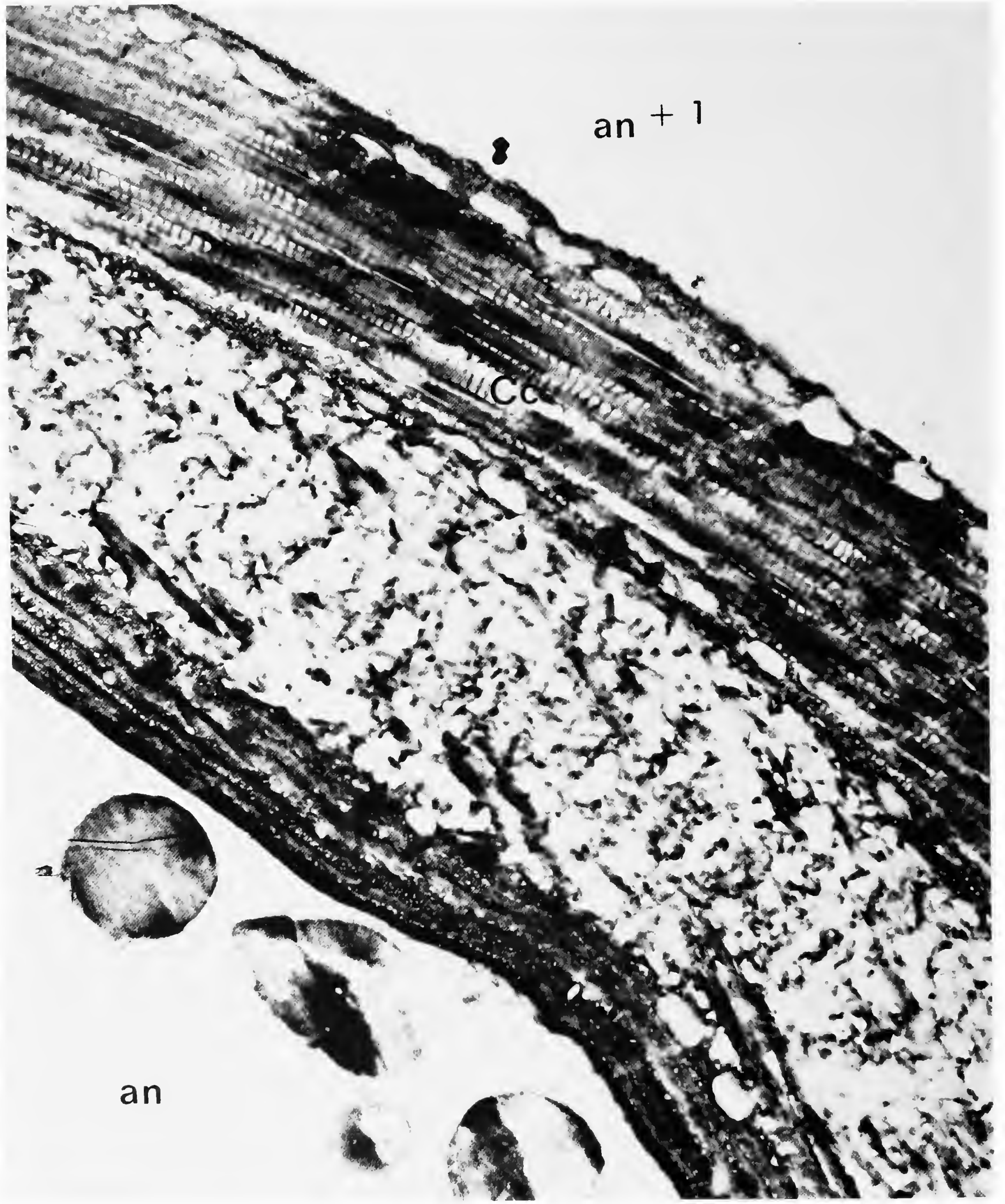

Plate 14.-Dictyonema sp. Portion of the inner thecal wall separating the cavities of autotheca- $a_{n}$ and autotheca- $a_{n+1}$. Note the presence of a cortical coating (Cc) ( $\left.X 22000\right)$. For comparison see diagram in Figure 1. 

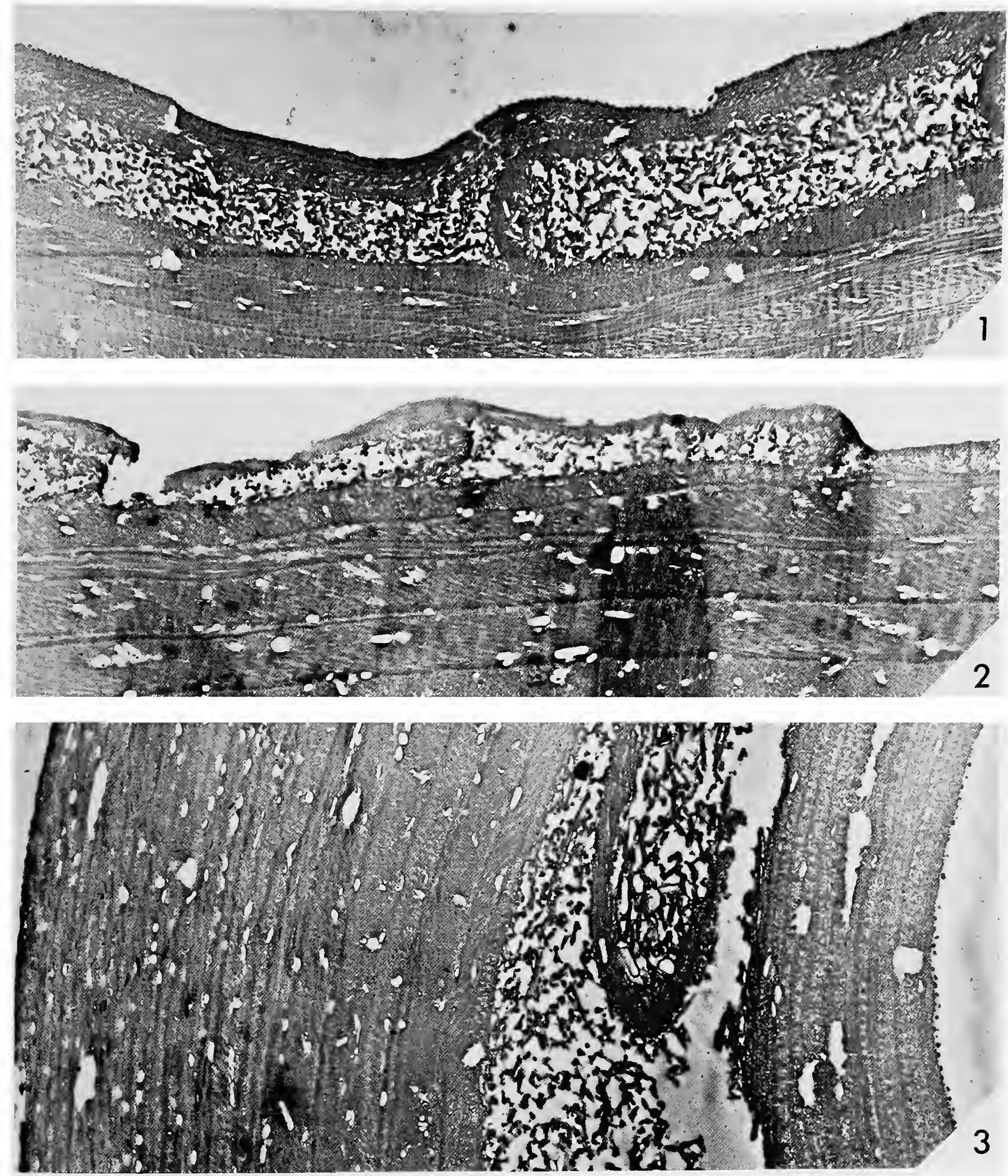

Plate 15.-Acanthograptus sp. Longitudinal sections illustrating different development of the fusellar component in the outer thecal walls. Figure 1 shows it is well developed $(\times 9000)$. Figure 2 shows it underdeveloped $(X 12000)$. Figure 3 shows a fully developed outer thecal wall $(x$ 14000). 


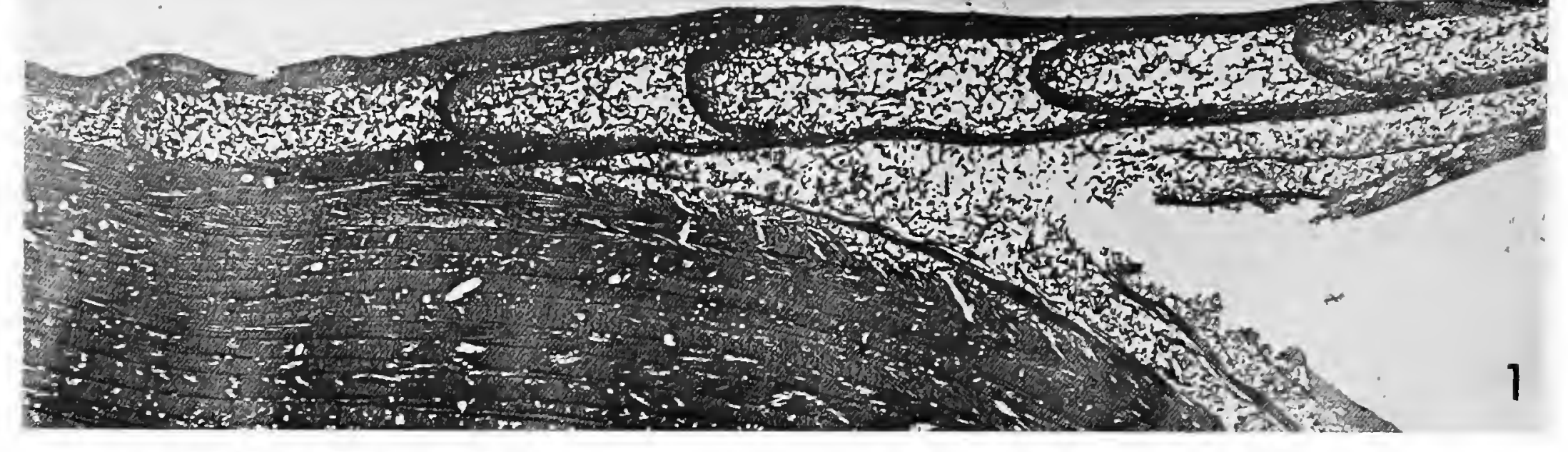

(5)

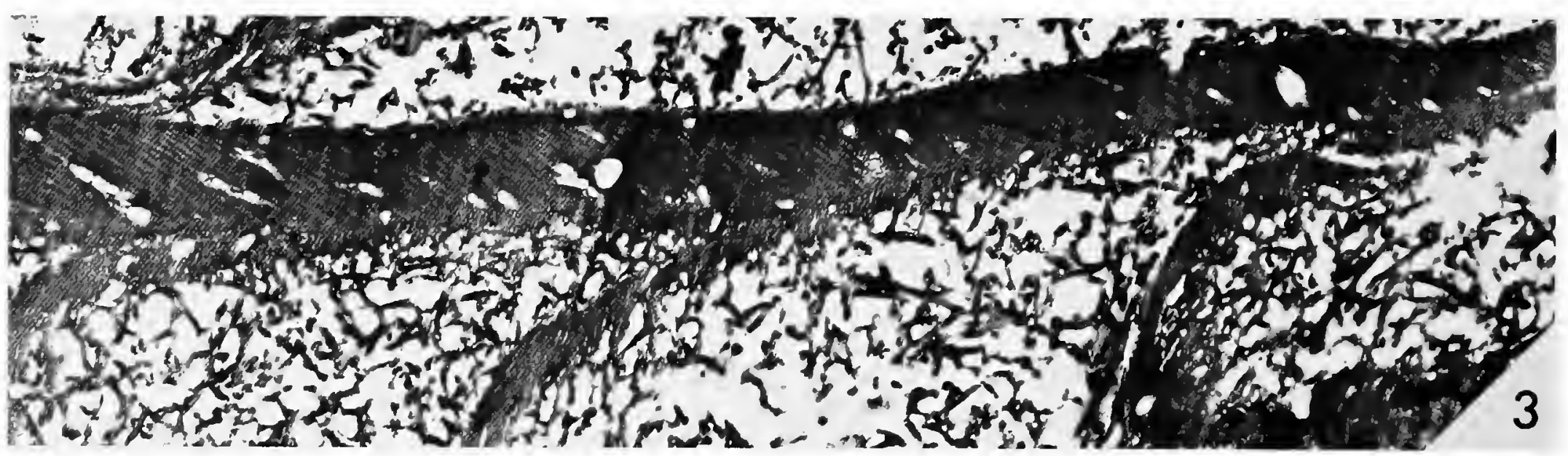

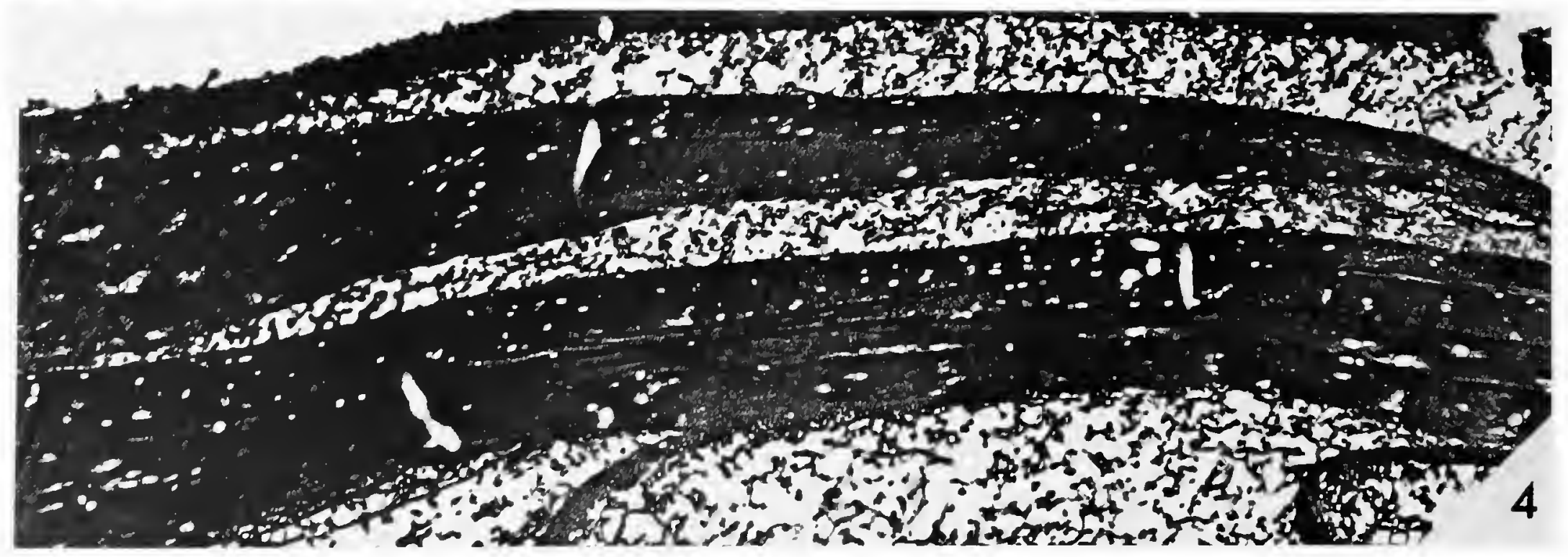

Plate 16.-Acanthograptus sp. Figures 1-3 illustrate the mode of formation of an internal cortical coating by means of an overlap of the outer lamellae of adjacent fuselli (figure 1, $\times 4000$; figure $2, \times 10000$; figure $3, \times 8000$ ). Figure 4 shows cortical intercalations between fuselli of the inner thecal wall $(\times 8000)$. 

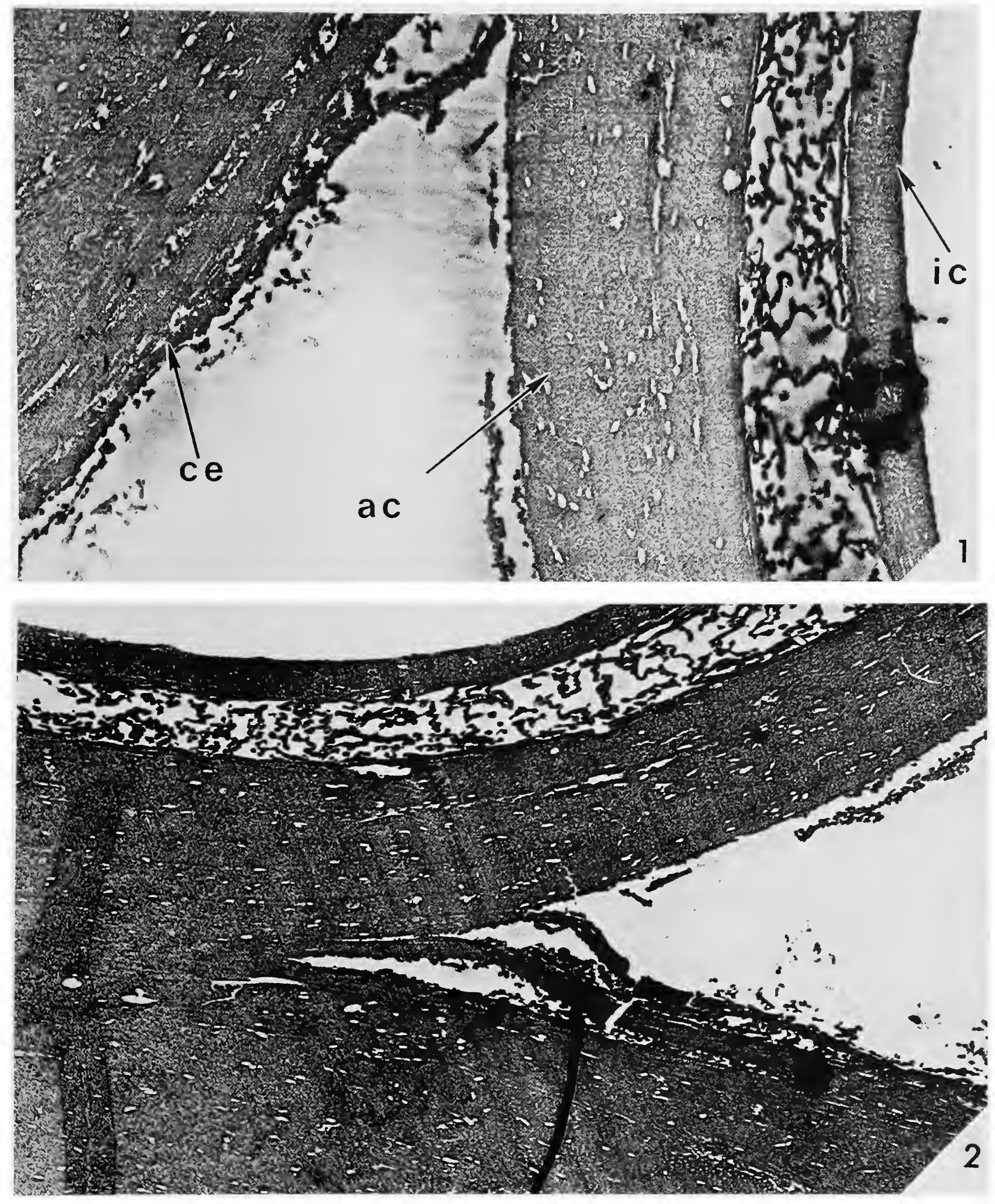

Plate 17.-Acanthograptus sp. Transverse section showing the merging of an outer and inner thecal wall. There is a merging of the outer cortical deposit of an autotheca (ac) with the common cortical envelope (ce) of the rhabdosome; ic is the inner cortical deposit of the autotheca (figure 1, $\times 12000$; figure $2, \times 6000$ ). 

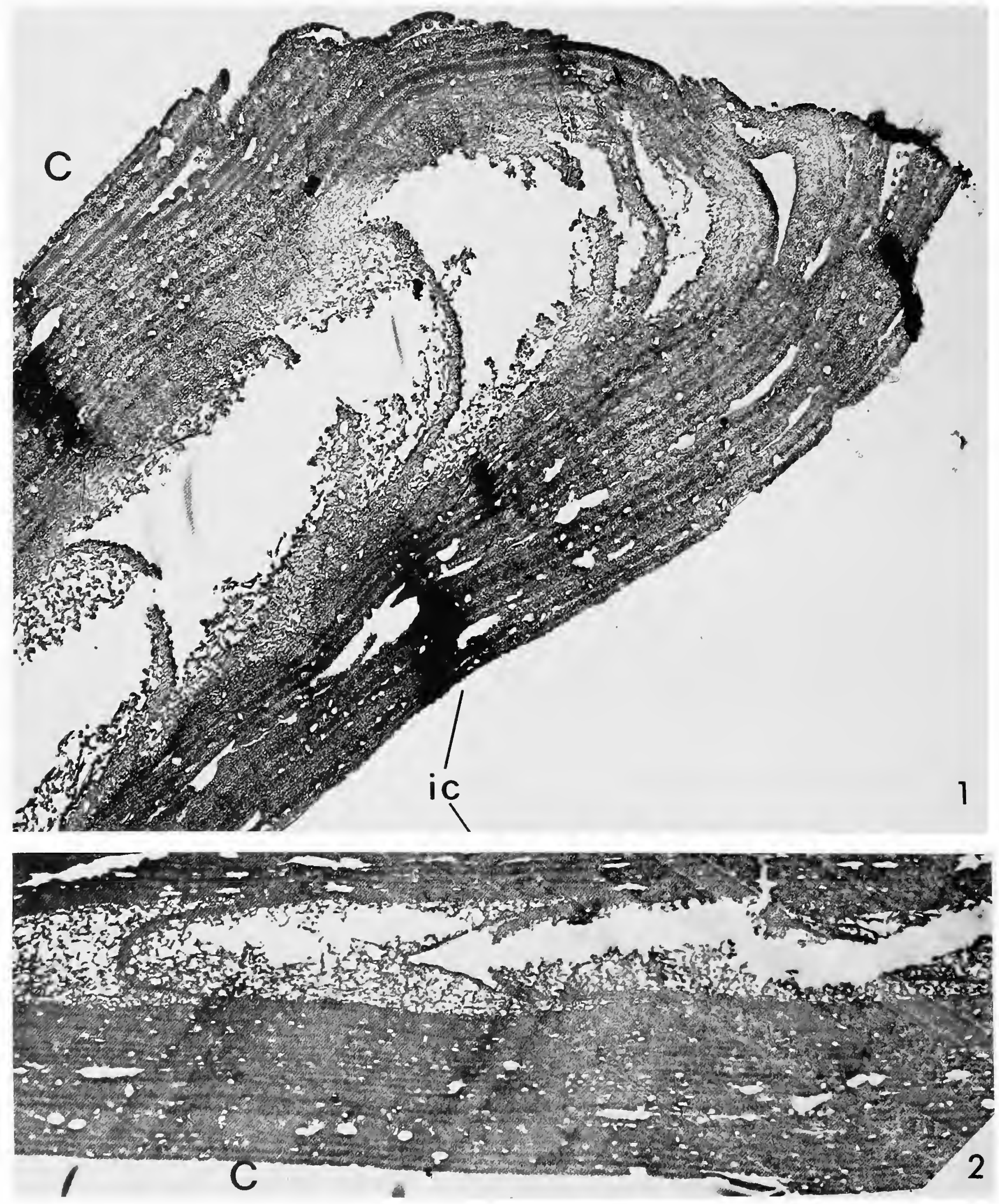

Plate 18-Acanthograptus sp. Structural features of a frce part of an autotheca producing a "twig" (figure $1, \times 11000$ ). Figure 2 shows a portion of the middle part of the wall and its cortex (C) and inner cortical coating (ic) ( $\times 11000)$. 

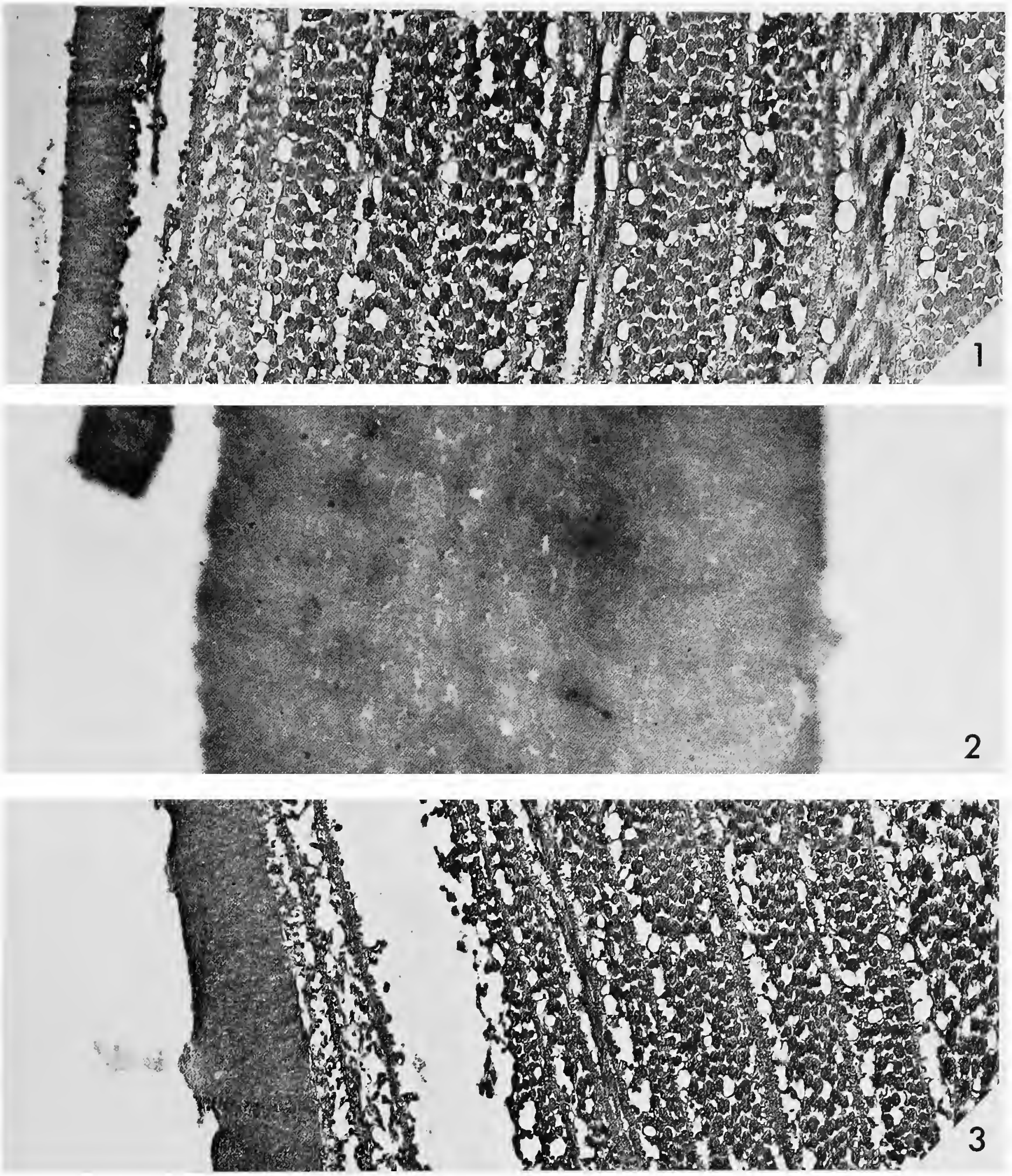

Plate 19.-Mastigograptus sp. (specimen 1). Secondary thecal walls made of ld-crassal fabric in an outer thecal wall (figure $1, \times 18000$ ), with details of the material within an inner wall (figure $2, \times 38000$ ), and a secondary thecal wall with the crassal fabric separated by a mesh material from the cortex (figure $3, \times 16000$ ). 

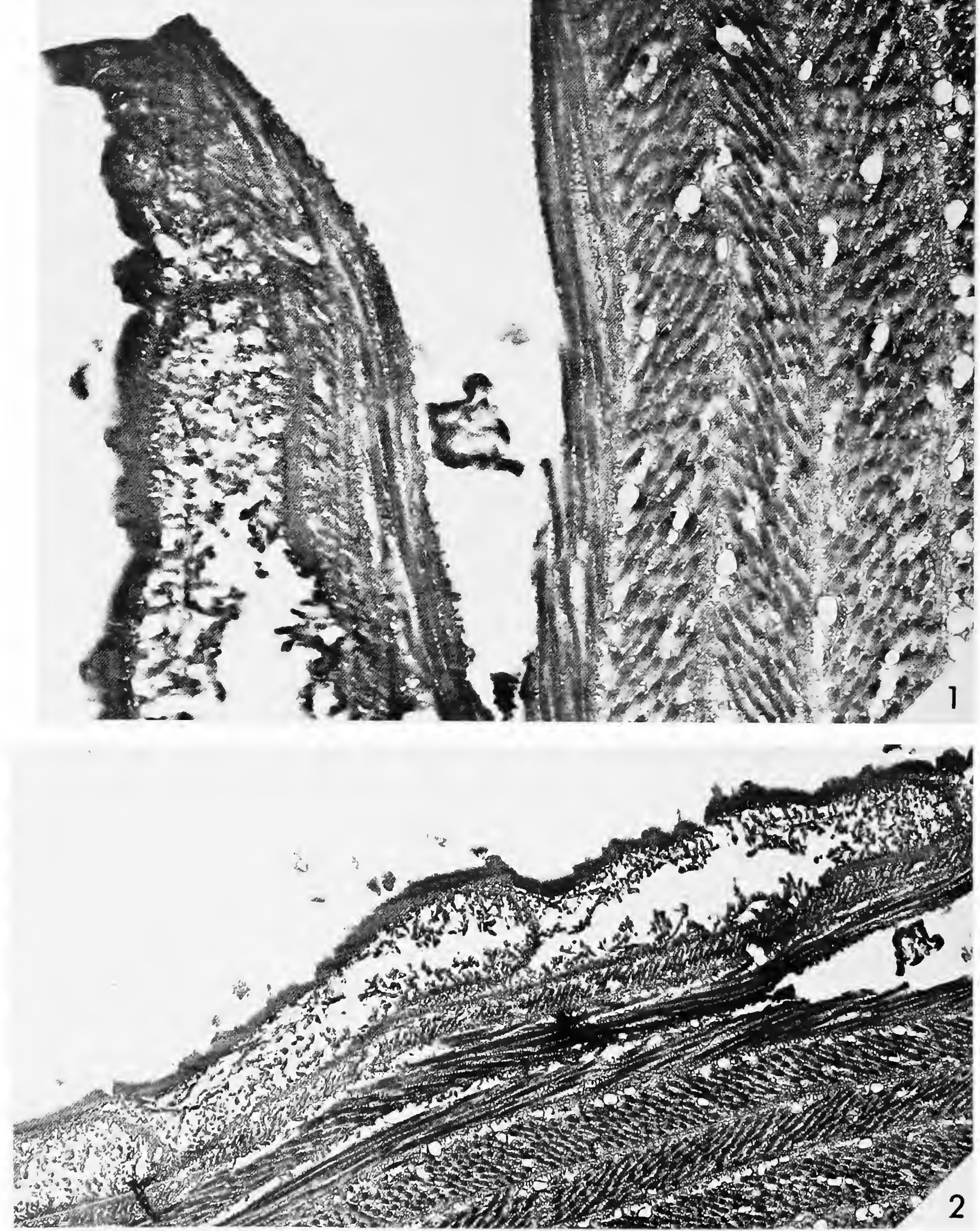

Plate 20._Mastigograptus sp. (specimen 1). Stem of the rhabdosome, with remnants of fuselli, forming a "promontory" surrounded by a secondary discontinuous homogeneous layer (figure $1, \times 20000$; figure $2, \times 10000)$. 


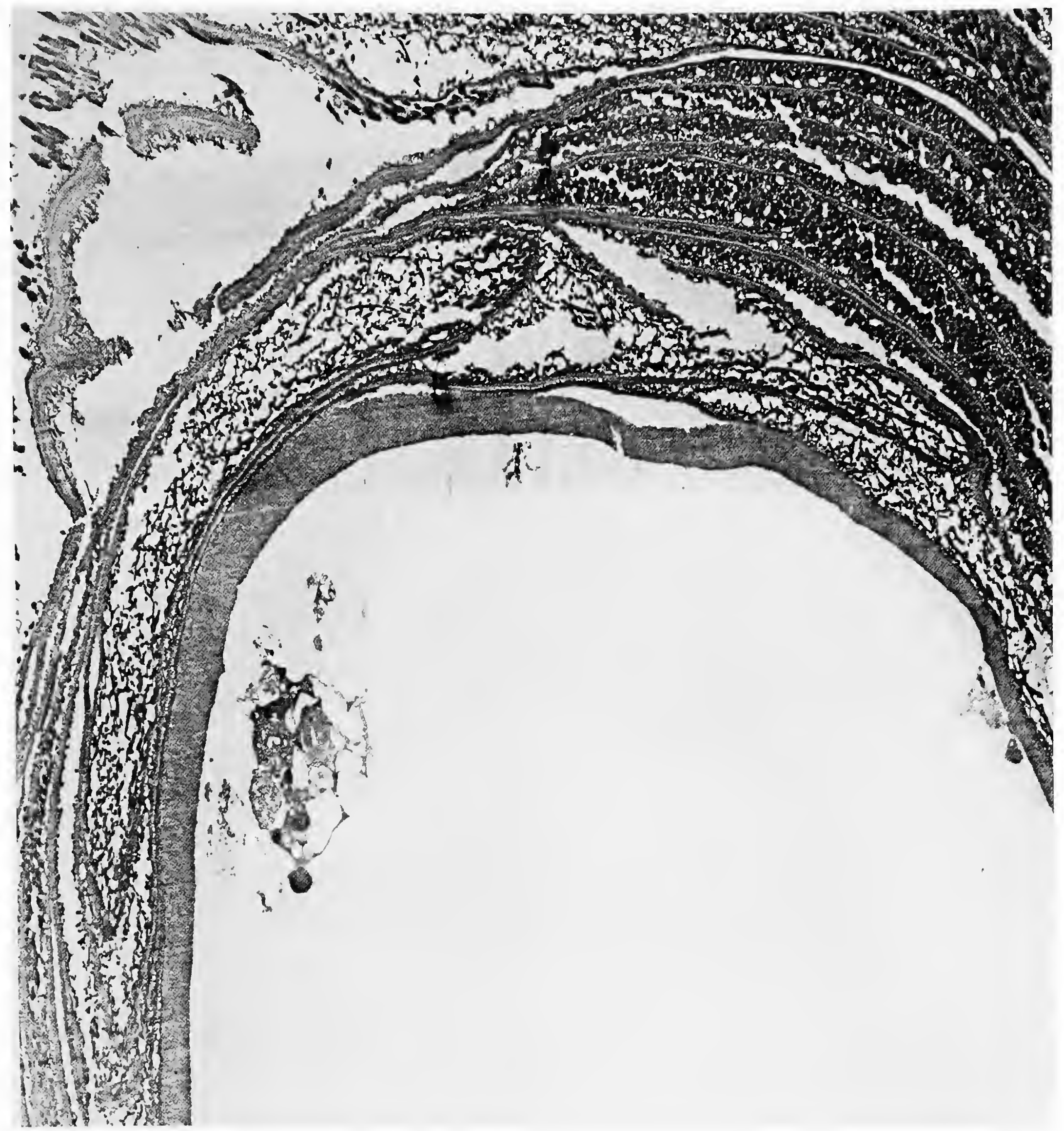

Plate 21.-Mastigograptus sp. (specimen 2). Transverse section through the stipe, showing fusellar thecal walls (primary thecal walls?) $(\times 8000)$. 

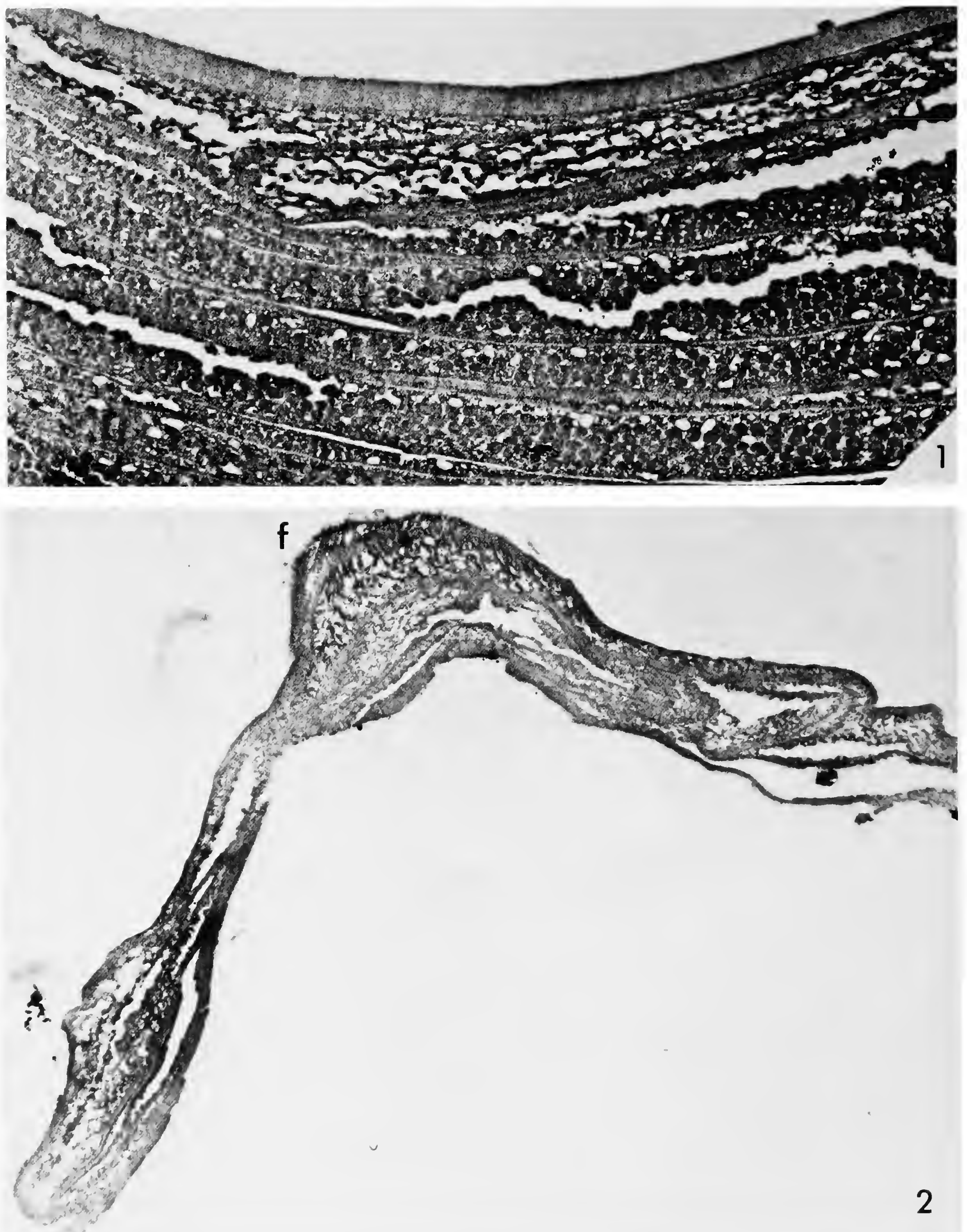

Plate 22.-Mastigograptus sp. (specimen 2). Outer thecal wall (figure 1, $\times 12000$ ) and free part of theca (autotheca?) stretching beyond the stipe. There are indistinct traces of fusellar boundaries at $f$ (figure $2, \times 8000$ ). 
NUMBER 20

41
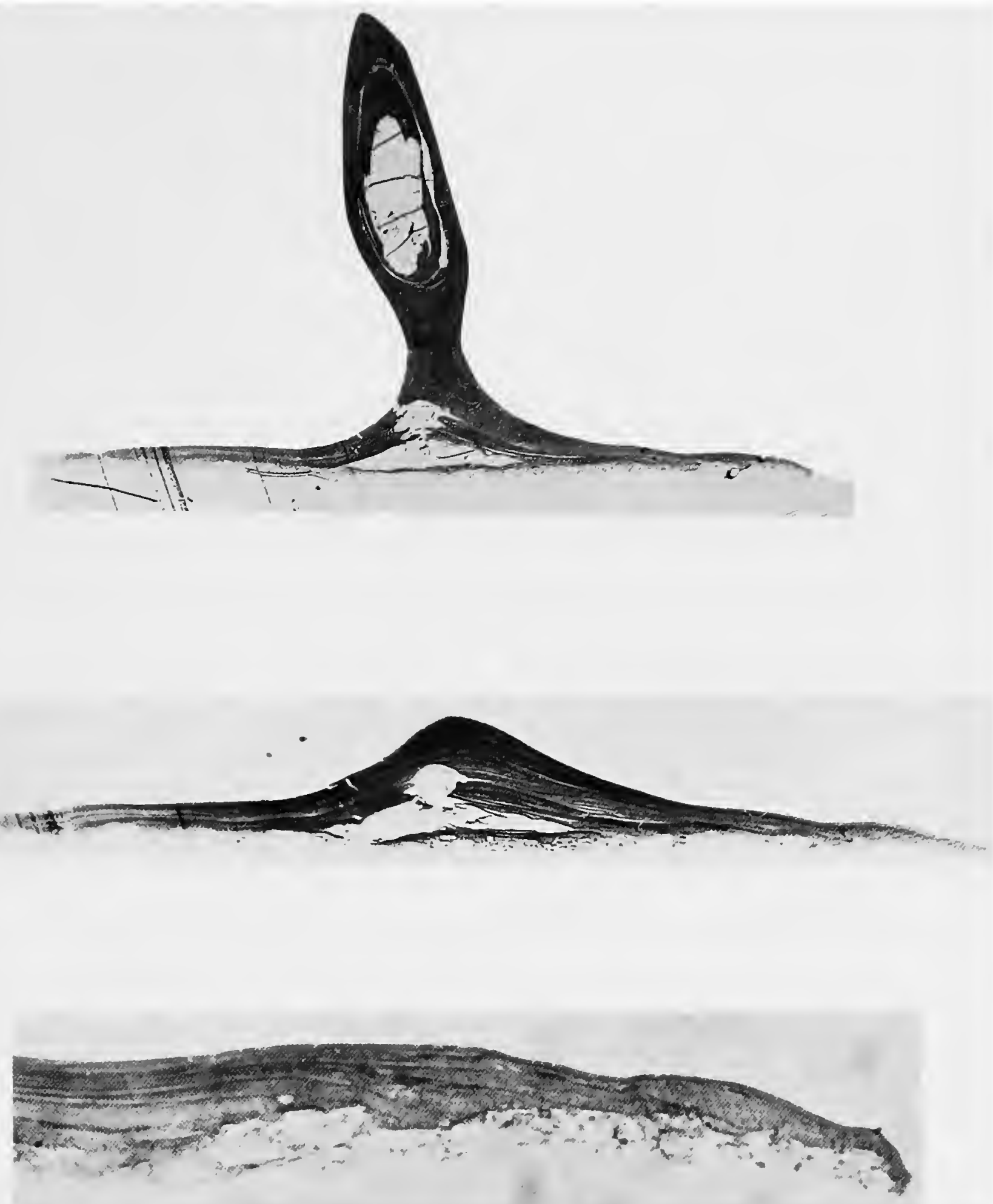

Plate 23.-Mastigograptus sp. Light micrograph of the basal disc (figure 1, $\times$ 85; figure 2, $\times 120$; figure $3, \times 520$ ). 
2.

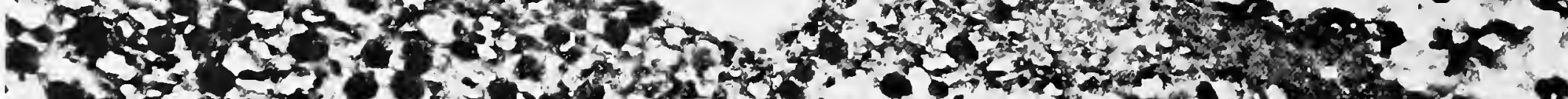

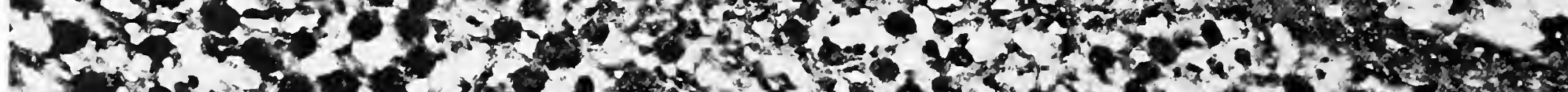

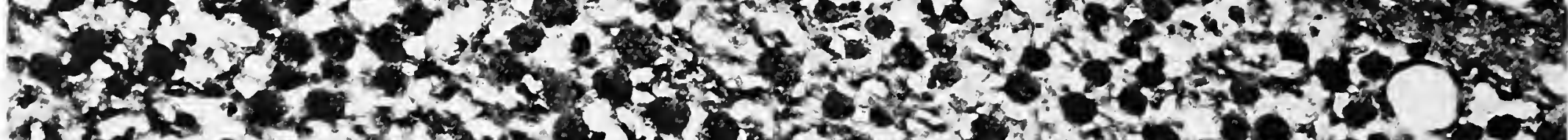

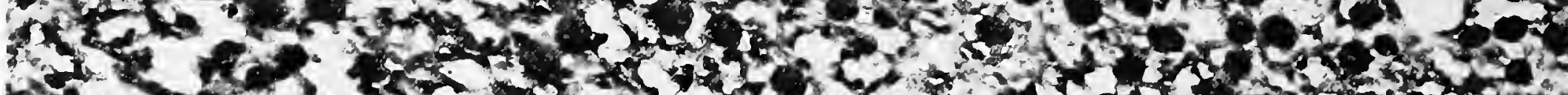

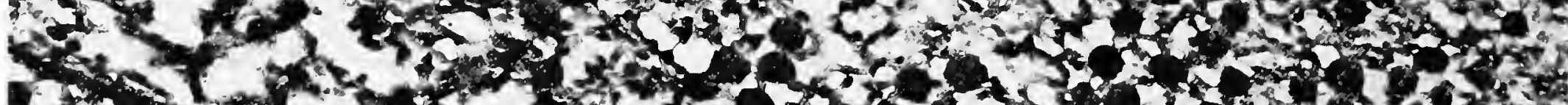

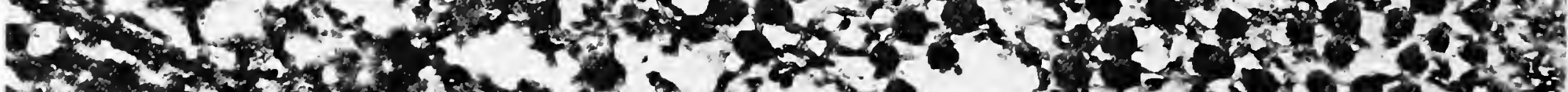

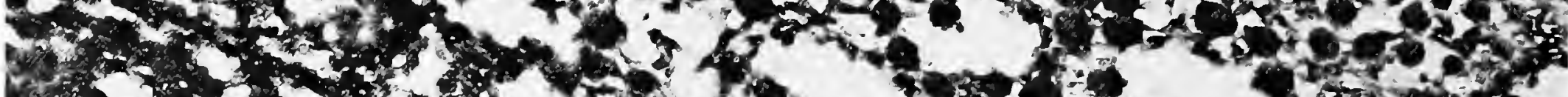

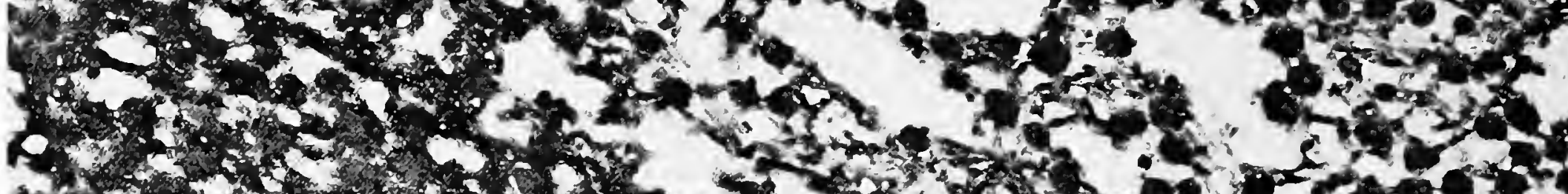

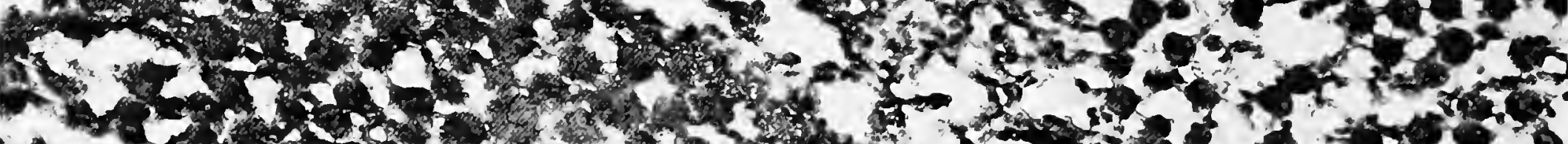

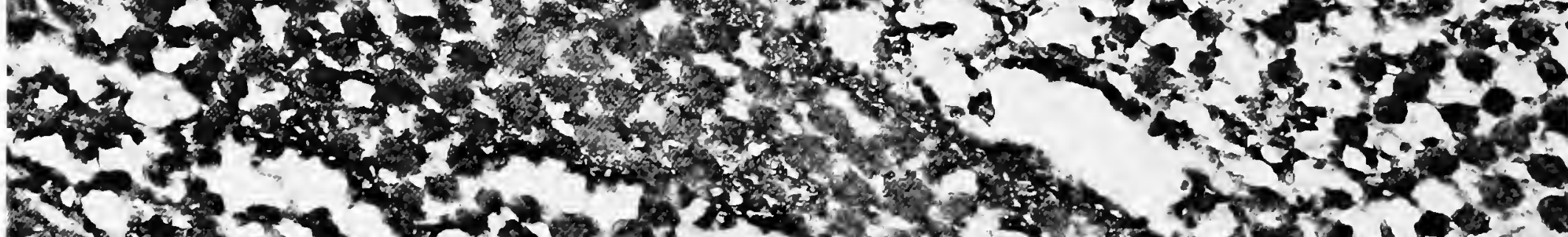

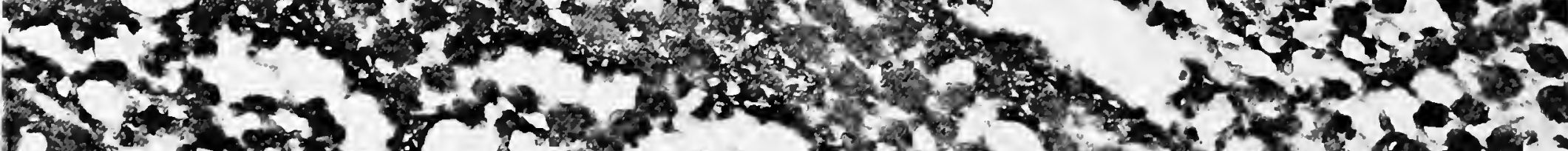

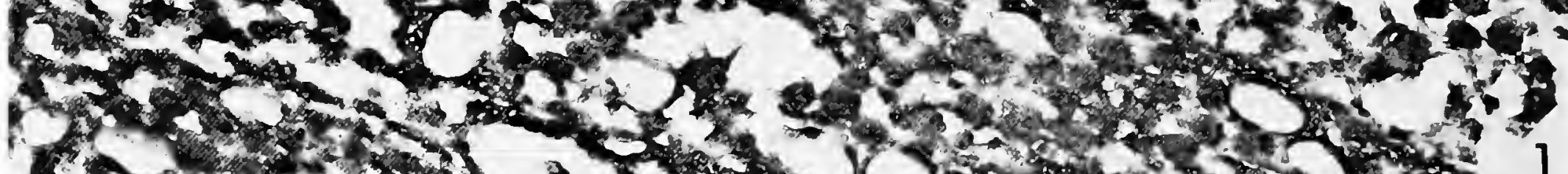
(1)

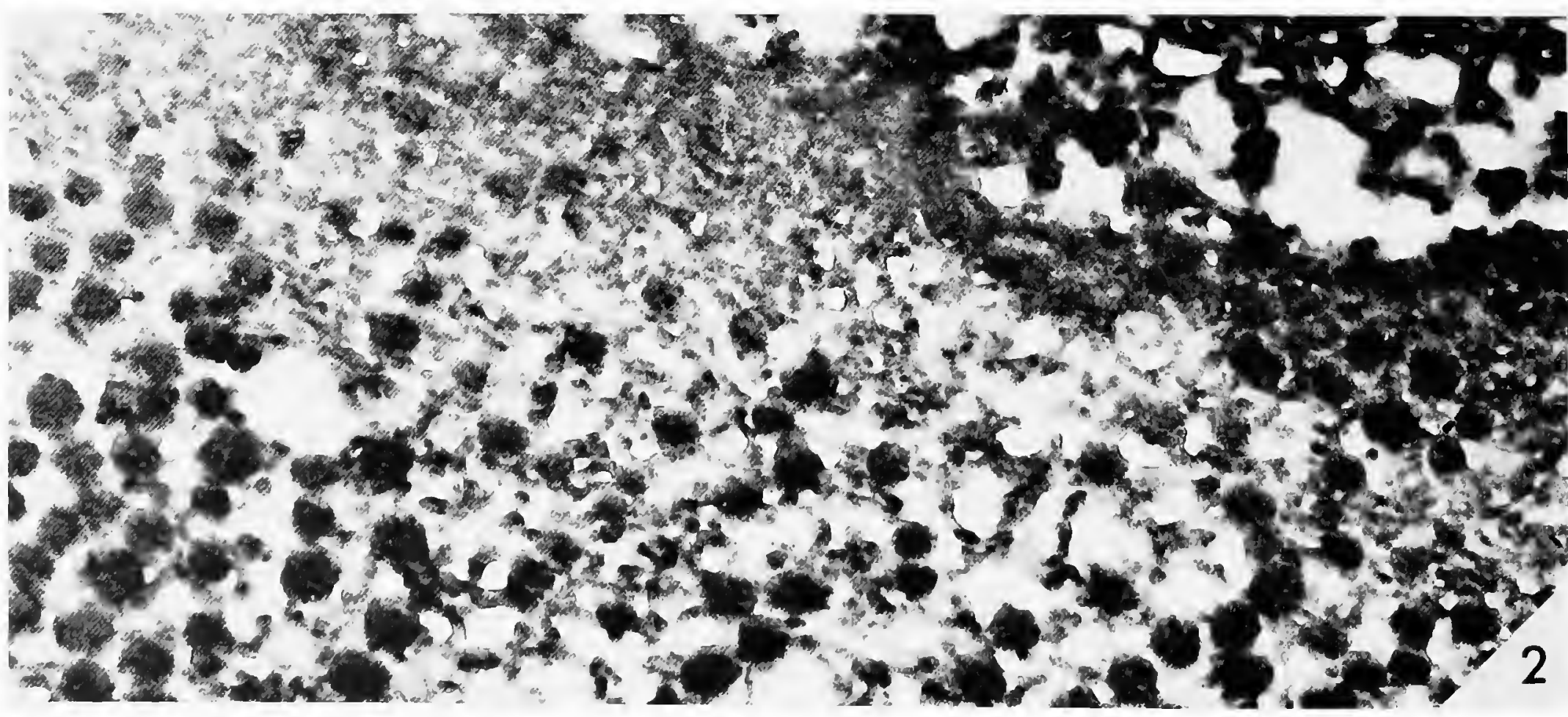

Plate 24_-Mastigograplus sp. Ultrastructural features of the upper layers of the basal disc (figure 1, $\times 26000$; figure $2, \times 45000$ ). 

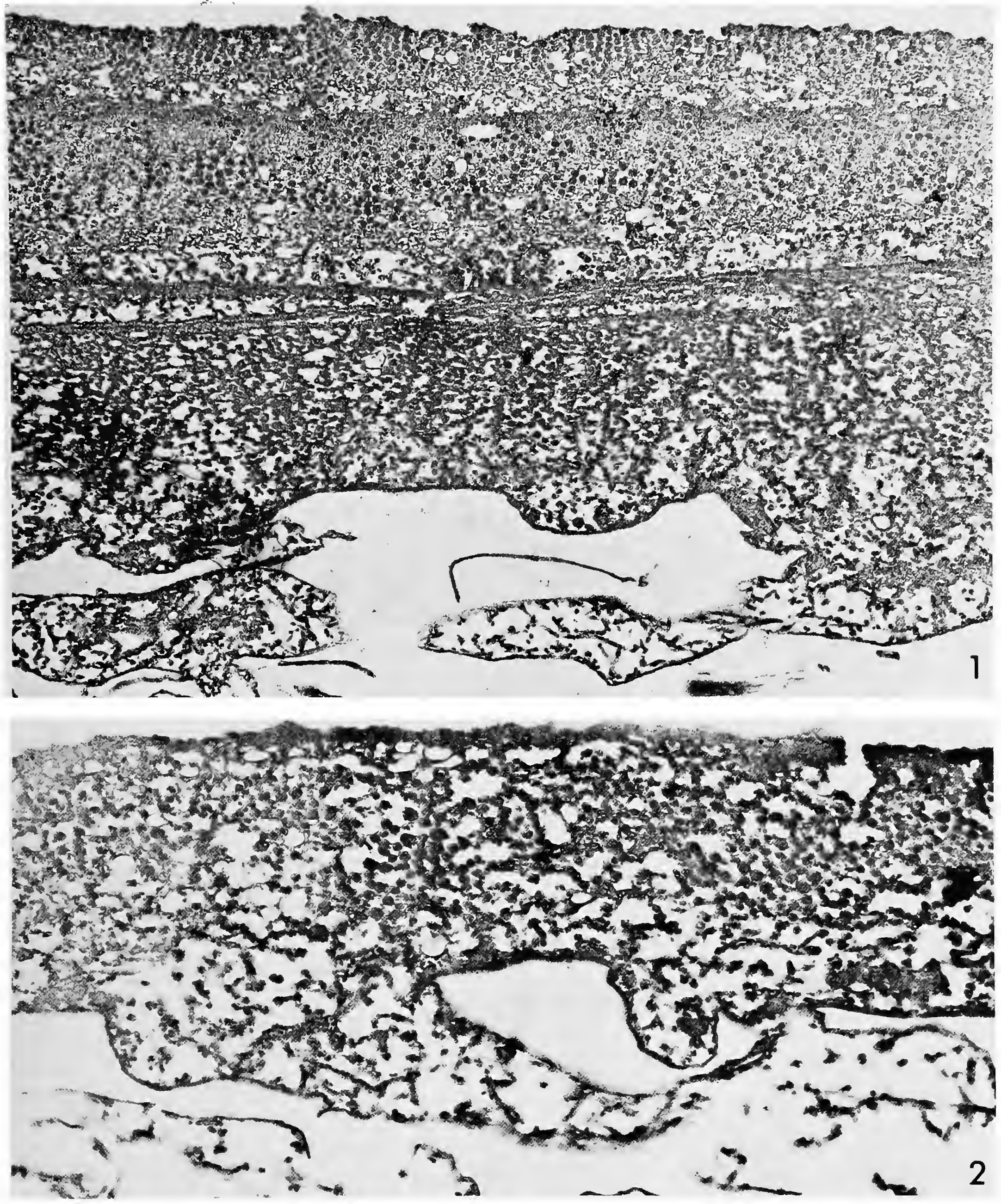

Plate 25.-Mastigograptus sp. Ultrastructural features of the lower portions of the basal disc (figure 1, $\times$ 9000; figure $2, \times 15000$ ). 


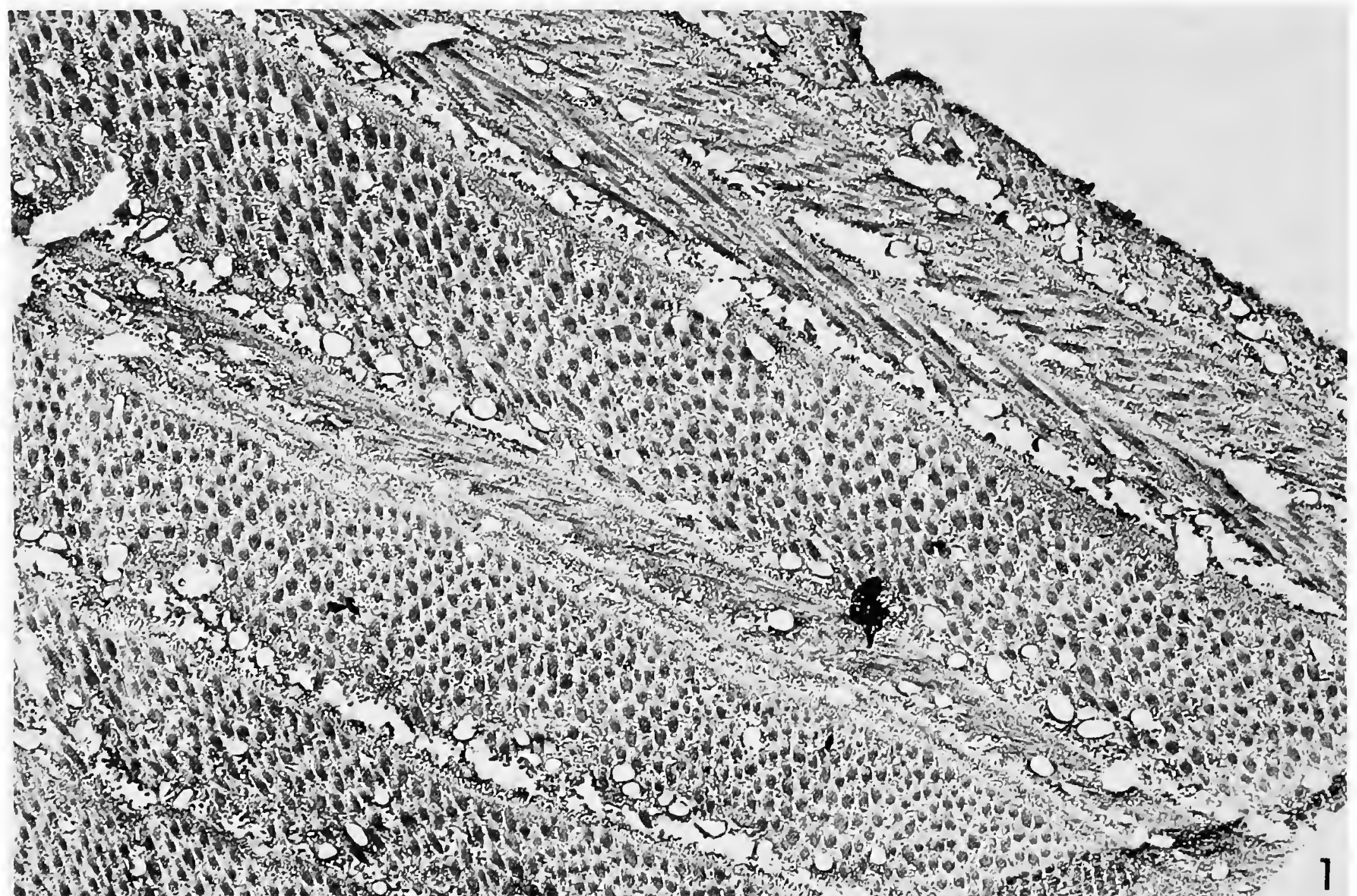

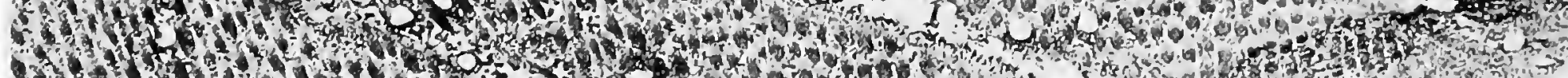

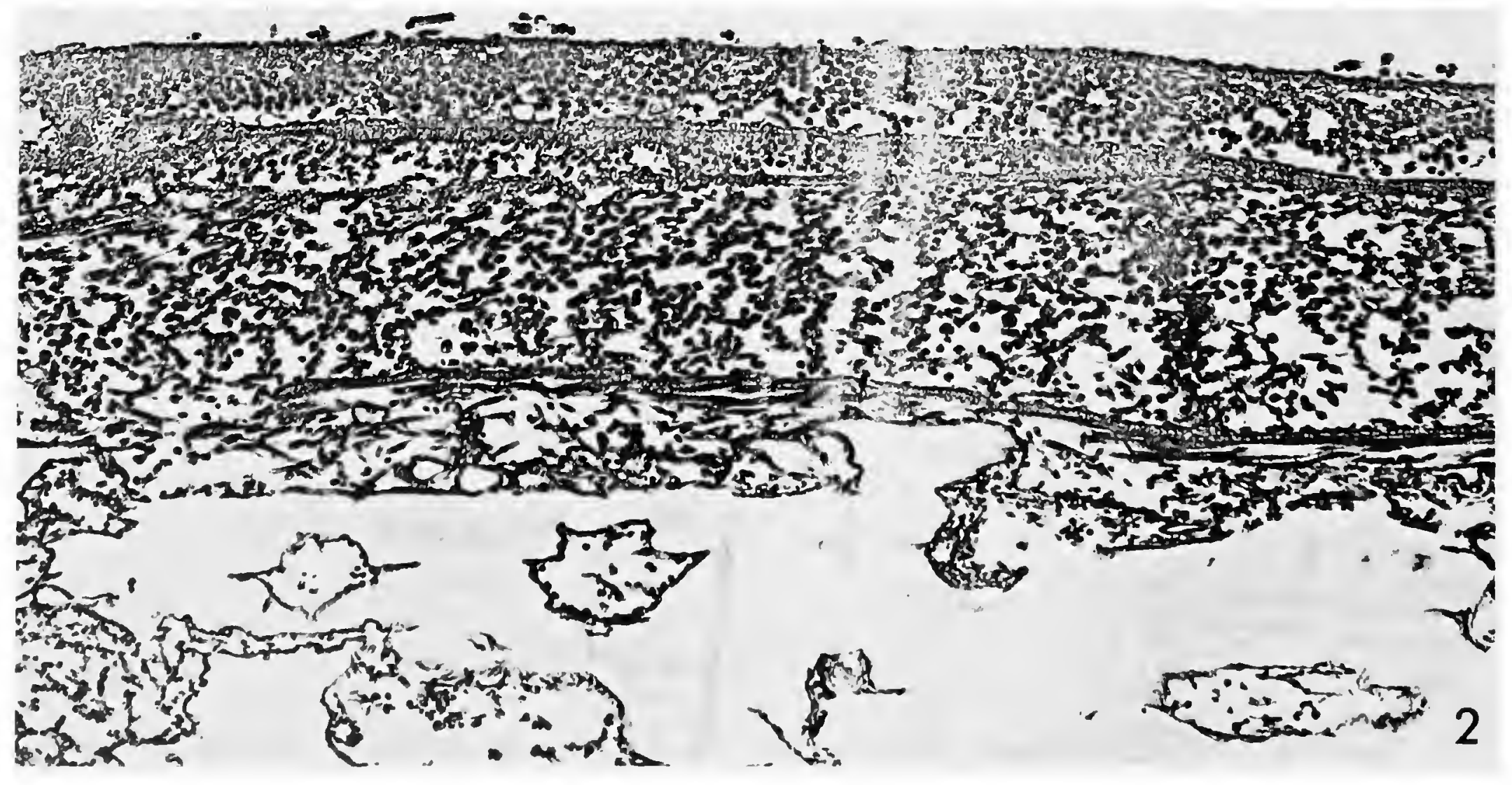

Plate 26.-Mastigograptus sp. ligure 1 is a section near the base of the "stem" and the basal disc $(\times 15000)$. Figure 2 is from lowermost layers $(\times 7000)$. 


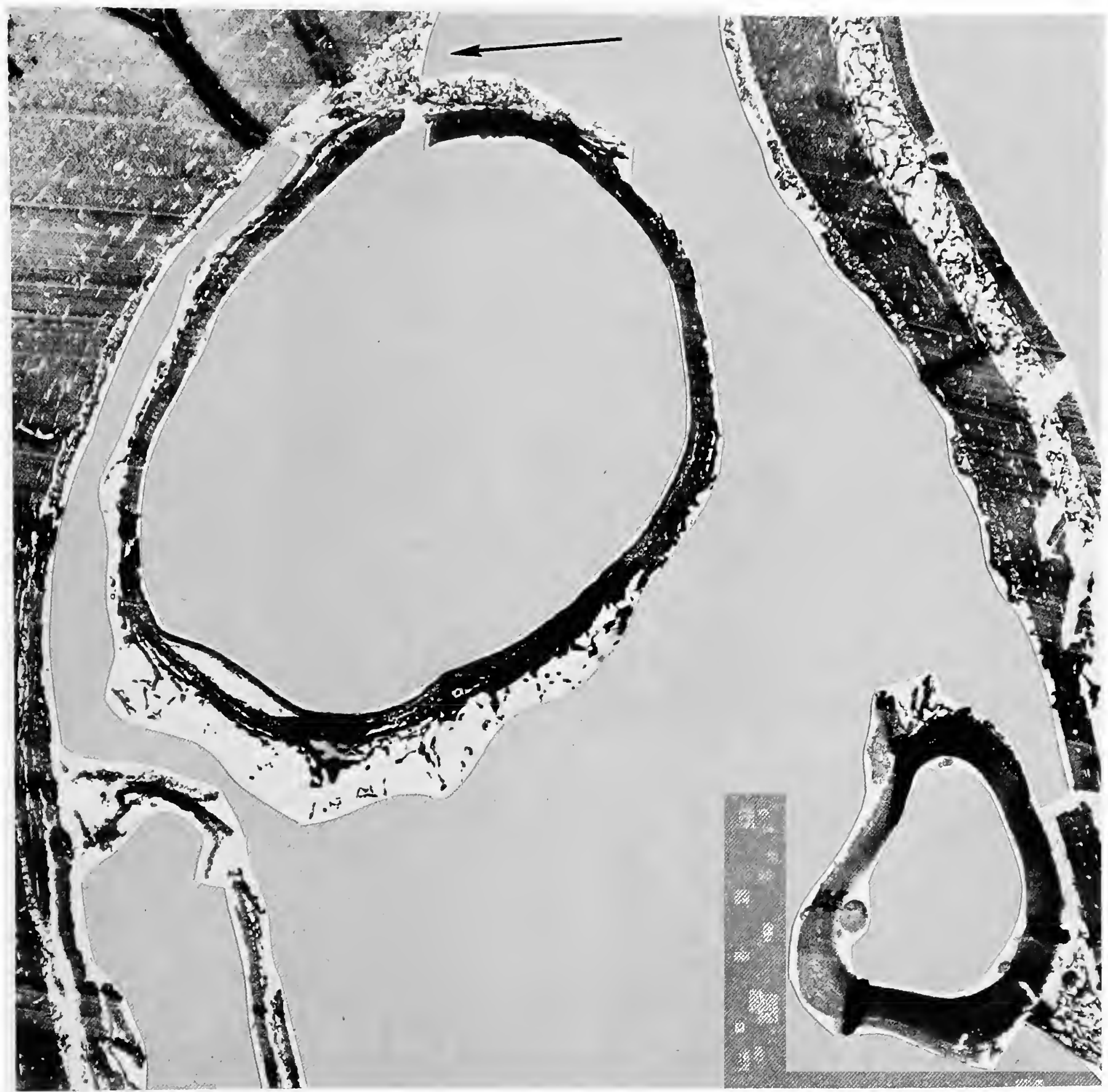

Plate 27.-Acanthograptus sp. Transverse section through a stolotheca, showing thick stolonal tubules and thin-walled internal part of a theca ( $X 3000)$. 


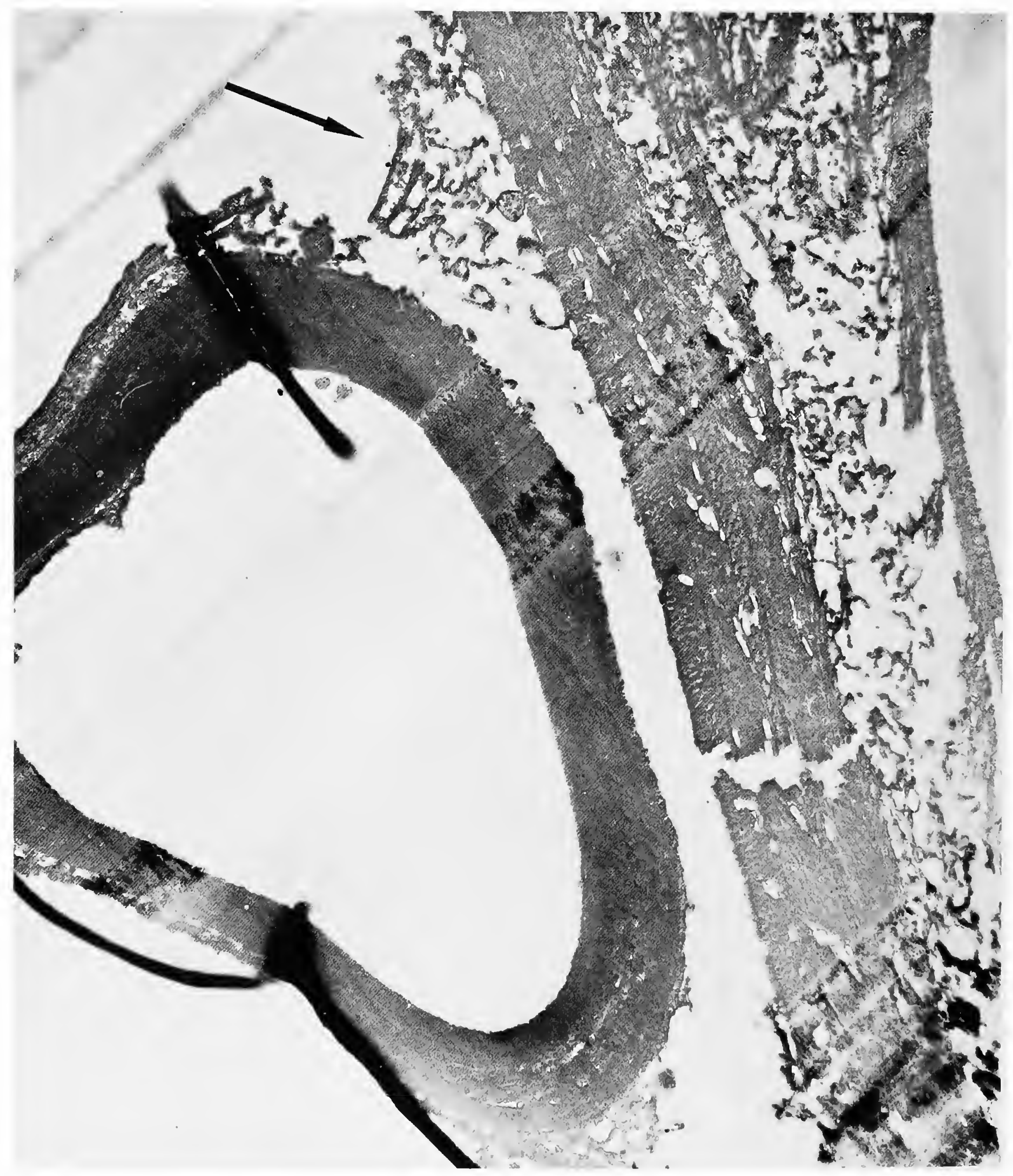

Plate 28.-Acanthograptus sp. Stolonal sheath of crassal fabric with spongy material (arrow) joining it to the wall of the stolotheca $(X 11000)$. 


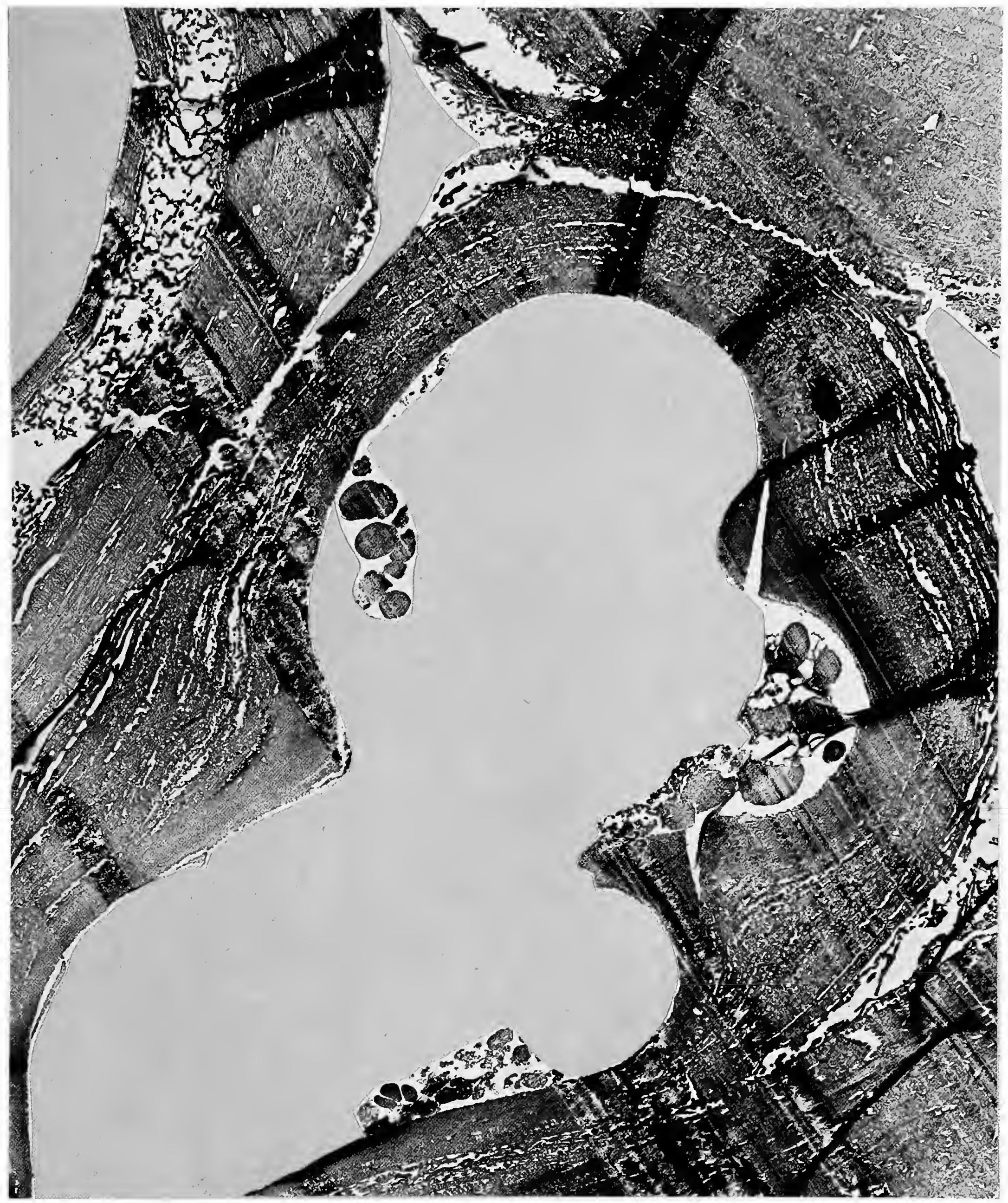

Plate 29.-Acanthograptus sp. Obliquely sectioned thick-walled stolonal sheaths with protuberances into the stolonal cavity $(X 5000)$. 


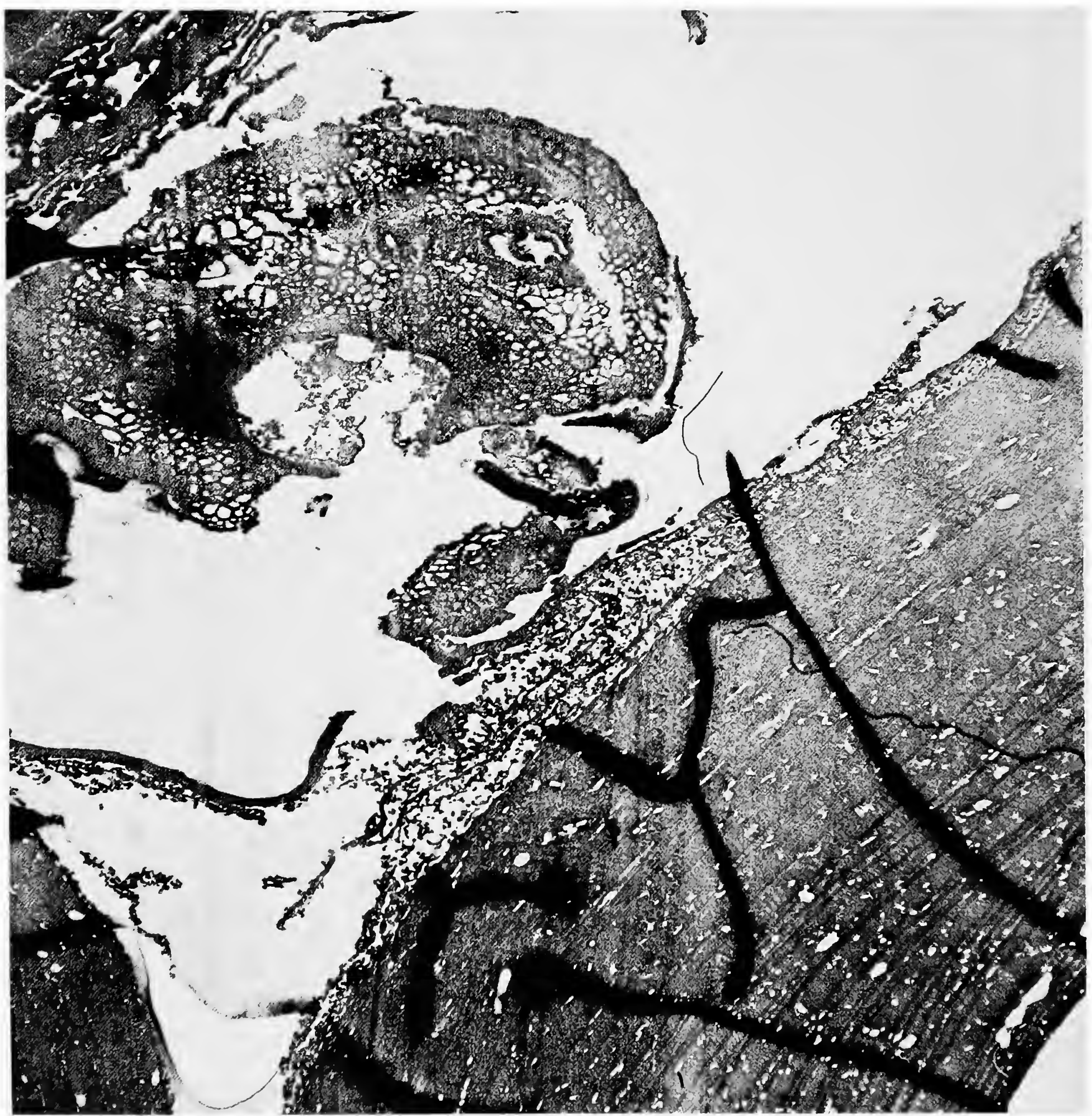

Plate 30.-Acanthograptus sp. Stolonal channel restriction of spongy aspect $(\times 7000)$. 


\section{Publication in Smithsonian Contributions to Paleobiology}

Manuscripts for serial publications are accepted by the Smithsonian Institution Press, subject to substantive review, only through departments of the various Srnithsonian museums. Non-Smithsonian authors should address inquiries to the appropriate department. If submission is invited, the following format requirements of the Press will govern the preparation of copy.

Copy must be typewritten, double-spaced, on one side of standard white bond paper, with $11 / 2 "$ top and left margin, submitted in ribbon copy with a carbon or duplicate, and accompanied by the original artwork. Duplicate copies of all material, including illustrations, should be retained by the author. There may be several paragraphs to a page, but each page should begin with a new paragraph. Number consecutively all pages, including title page, abstract, text, literature cited, legends, and tables. The minimum length is 30 pages, including typescript and illustrations.

The title should be complete and clear for easy indexing by abstracting services. Taxonomic titles will carry a final line indicating the higher categories to which the taxon is referable: "(Ammonoidea: Goniatitidae)." Include an abstract as an introductory part of the text. Identify the author on the first page of text with an unnumbered footnote that includes his professional mailing address. A table of contents is optional. An index, if required, may be supplied by the author when he returns page proof.

Two headings are used: (1) text heads (boldface in print) for major sections and chapters and (2) paragraph sideheads (caps and small caps in print) for subdivisions. Further headings may be worked out with the editor.

In taxonomic keys, number only the first item of each couplet; if there is only one couplet, omit the number. For easy reference, number also the taxa and their corresponding headings throughout the text; do not incorporate page references in the key.

In synonymy, use the short form (taxon, author, date:page) with a full reference at the end of the paper under "Literature Cited." Begin each taxon at the left margin with subsequent lines indented about three spaces. Within an entry, use a period-dash $(-\rightarrow)$ to separate each reference. Enclose with square brackets any annotation in, or at the end of, the entry. For references within the text, use the author-date system: "(Jones, 1910)" and "Jones (1910)." If the reference is expanded, abbreviate the data: "Jones (1910:122, pl. 20: fig. 1)."

Simple tabulations in the text (e.g., columns of data) may carry headings or not, but they should not contain rules. Formal tables must be submitted as pages separate from the text, and each table, no matter how large, should be pasted up as a single sheet of copy.

Use the metric system instead of, or in addition to, the English system.

Illustrations (line drawings, maps, photographs, shaded drawings) can be intermixed throughout the printed text. They will be termed Figures and should be numbered consecutively; however, if a group of figures is treated as a single figure, the components should be indicated by lowercase italic letters on the illustration, in the legend, and in text references: "Figure 96." If illustrations (usually tone photographs) are printed separately from the text as full pages on a different stock of paper, they will be termed Plates, and individual components should be lettered (Plate 9b) but may be numbered (Plate 9: figure 2). Never combine the numbering system of text illustrations with that of plate illustrations. Submit all legends on pages separate from the text and not attached to the artwork. An instruction booklet for the preparation of illustrations is available from the Press on request.

In the bibliography (usually called "Literature Cited"), spell out book, journal, and article titles, using initial caps with all words except minor terms such as "and, of, the." For capitalization of titles in foreign languages, follow the national practice of each language. Underscore (for italics) book and journal titles. Use the colon-parentheses system for volume, number, and page citations: "10(2):5-9." Spell out such words as "figures," "plates," "pages."

For free copies of his own paper, a Smithsonian author should indicate his requirements on "Form 36" (submitted to the Press with the manuscript). A non-Smithsonian author will receive 50 free copies; order forms for quantities above this amount with instructions for payment will be supplied when page proof is forwarded. 
